اتجاهات القائمين بالاتصال في المجال الديني من قضية تجديد الخطاب الديني

\title{
دراسة ميدانية
}

د أبه / محمد علي أبو العـلا قنديل"

أولاً: مقدمة : (1)

إذا كان الفكر هو الذي يحرك الحياة فإن التجديد في الفكر وفي الحياة متلازمان

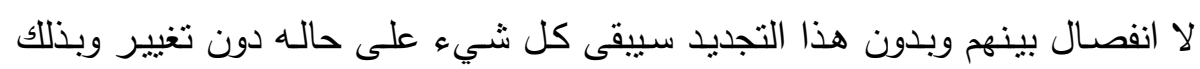

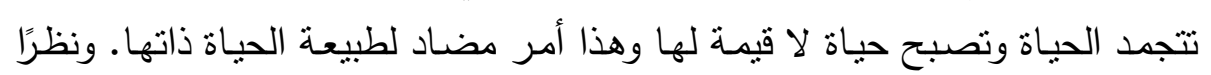
لأن الفكر الديني يعد جزءاً من الفكر الإنساني فإنه يمكن القول بـأن تجديد الفكر ألهر الديني يعد ضرورة حياتية.

والحديث عن التجديد في الفكر الديني في الإسـام بستداعي في الذهن الحندي الحديث

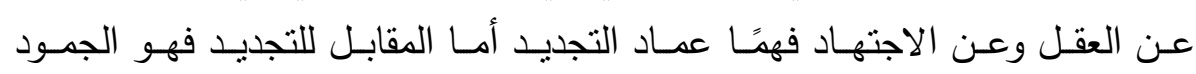
والانغلاق.

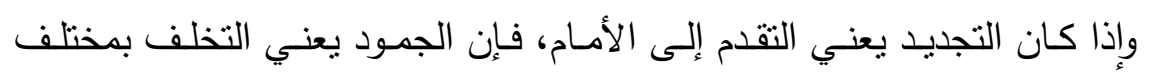

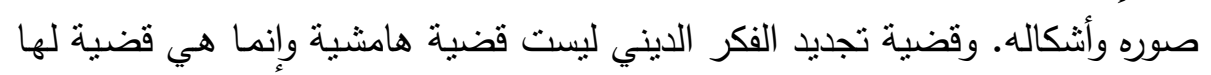

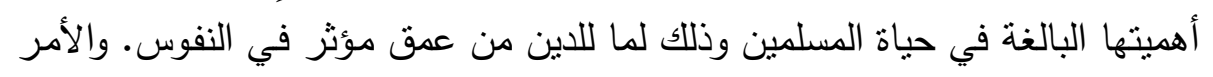

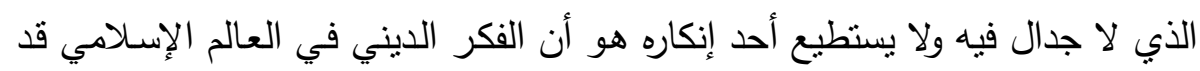

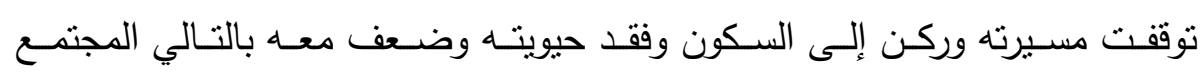

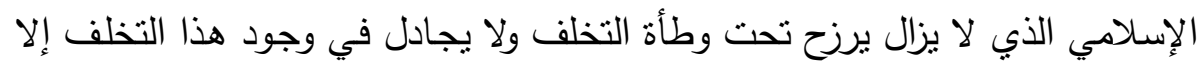
مكابر (1). ويقصد هنا بالتجديد هو تجديد الفكر الديني بصفة خاصة. وفي البداية نود أن

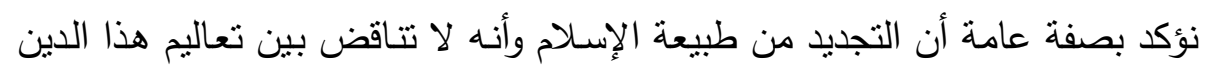

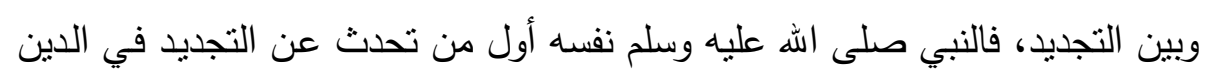

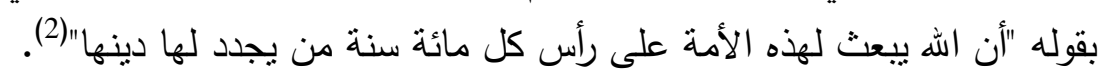

* مدرس علاقات عامة - قسم الإعلام - كلية الآداب - جامعة كفر الثيخ 
وإذ كان القرآن يعتبر الكون متغيرًا وأن ذلك في الآيات الدالة على الوجود الإلهي

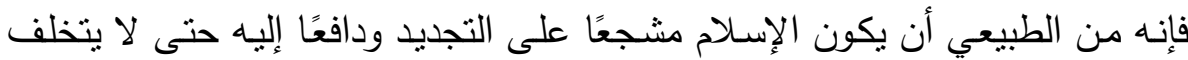
المجتمع الإسلامي عن ركب النطور . الطبان.

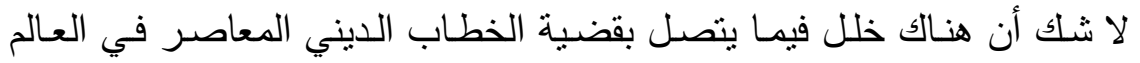

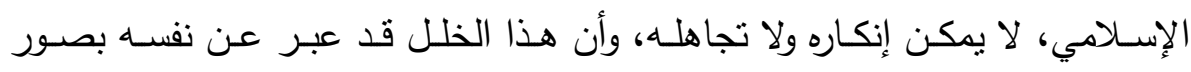
مختلفة وصلت لاختزال الإسلام في الوقت الراهن في كلمنين اثنتين هما: (الإرهاب)،

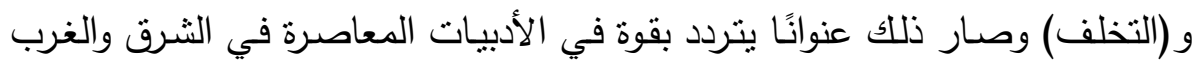

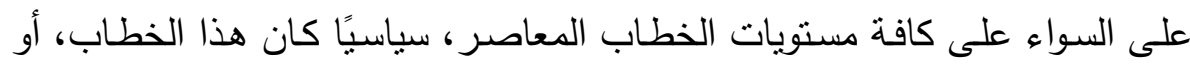

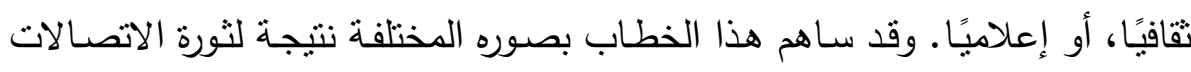

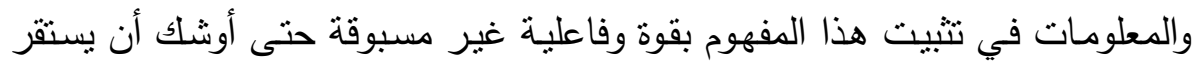
ذللك المفهوم السلبي عن الإسـلام كدين يُولد الإرهاب ويُكرس التخلف كصفة لإزمة فئة

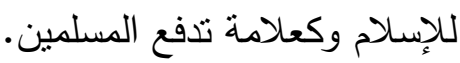

وقد خرجت الدعوة إلى ضرورة تجديد الخطاب الديني والدعوى باعتباره إنكالية

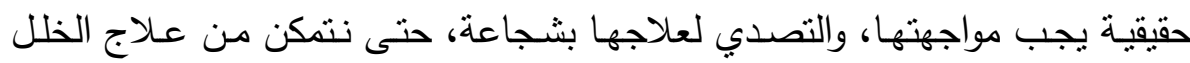

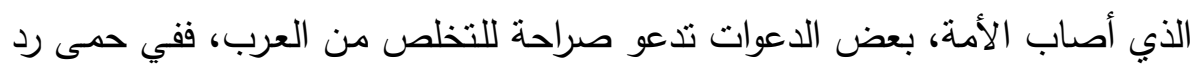

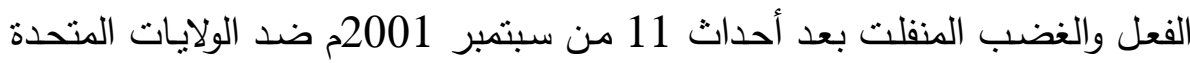

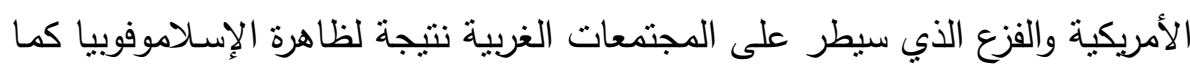

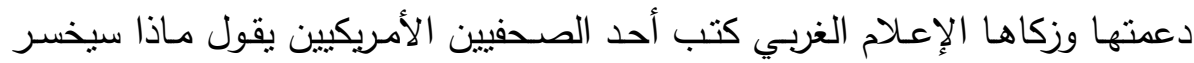

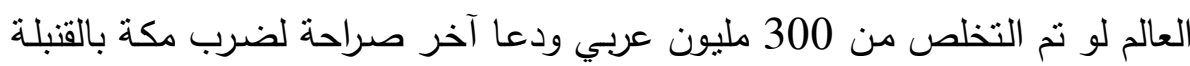

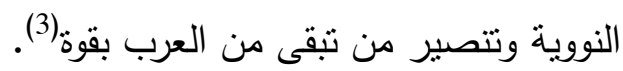

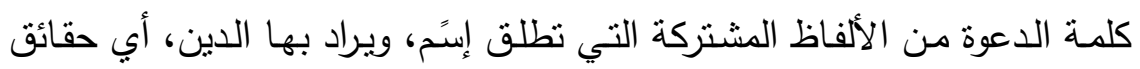

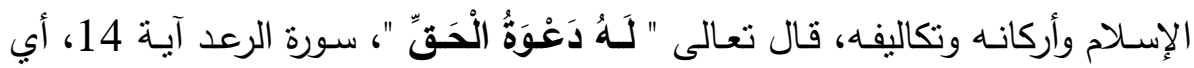

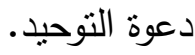
والدعوة بهذا المعنى مرادفة لمفهوم الاتصال الذي يعني كما يقول الباحث "كارل

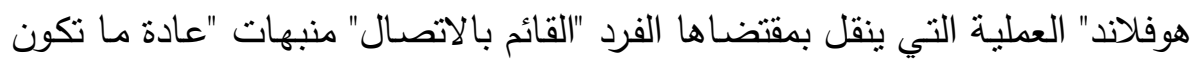
رموز لغوية" لكي يعدل سلوك الأفراد الآخرين "مستقبلي الرسالة". 
والدعوة لغة من الدعاء إلى الثيء بمعنى الحث على قصره، أو المحاولة العملية

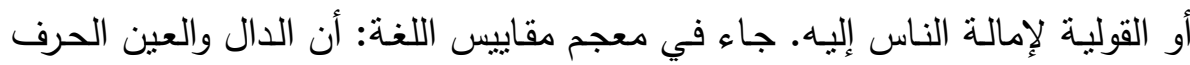

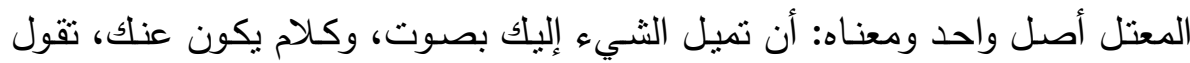
دعوت أدعو دعاء.

وجاء في المصباح المنير : دعوت الله أدعو دعـاء: أي ابتهلت إليهه بالسؤال ورغبت فيما عنده من الخير ودعوت زيدًا: ناديته، ودعا المؤذن إلى الصـلاة: فهو الئه داعي الله والجمع دعاة) (4).

وقد عرفها البعض من العلماء بأنها قيام العلماء والمستتيرين في الدين بتعليم

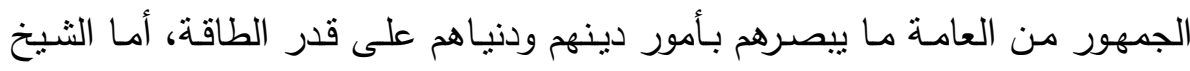

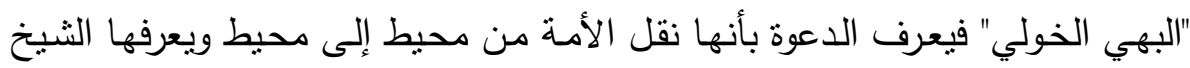

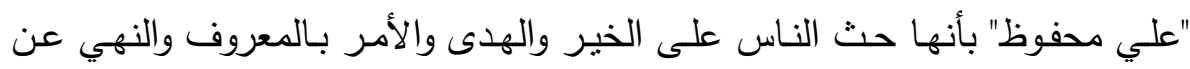
المنكر ليفوزوا بسعادة الدارين(5).

ولتحديد مفهوم الدعوة تحديدًا جامعًا مانعًا لابد أن ننظر إليها على أنها اتصال

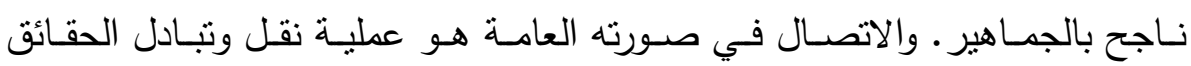

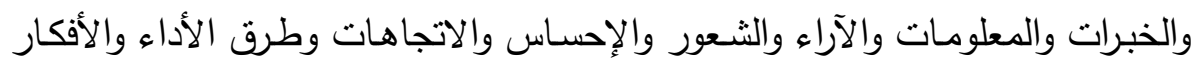

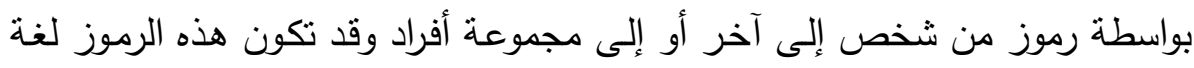
أو أرقاماً أو رسوماً أو غيرها.

ولكي يتحقق الاتصال الناجح لابد من توافر مقومات عديدة هي (6):

( أ ) مرسل، لايه أفكار أو معلومات أو خبرات أو وجهات نظر معينة يريد نوصيلها. وهذا المرسل في مجال الإعلام الديني قد يكون فرد أو جماعة أو هيئة. (ب) مستقبل، وهو الذي توجه إليه الرسالة من المرسل بأفكاره وآرائه واتجاهاته.

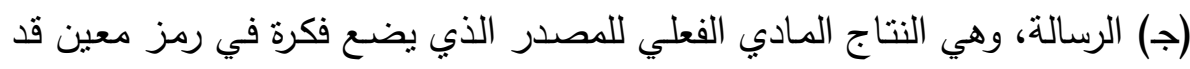

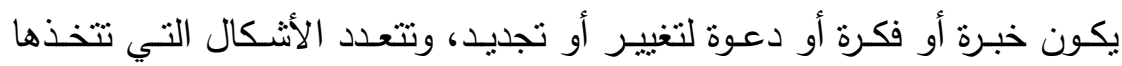

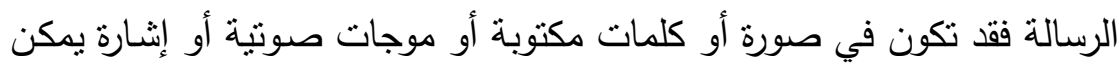


( د ) الوسيلة، وحينما يتم ترجمة هذه الصورة الذهنية إلى رموز فإنها تصبح قابلة

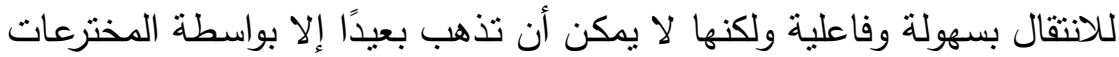

(هـ) التأثير ، والتأثير هنا قد يستهـف التأثثر الديني البحت كتغيير السلوك نحو

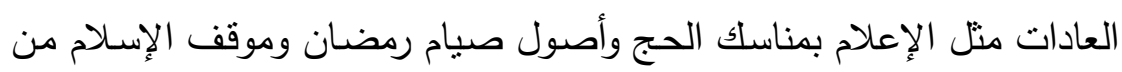

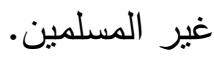

( و ) البحوث، وتمثل البحوث الخطوة الأولى الأساسية في نجاح الدعوة، وتستمد الأنس

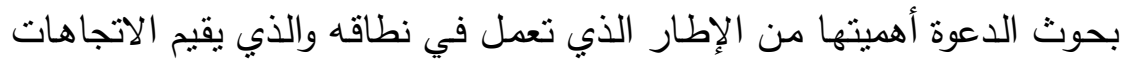
والقيم والرغبات والحاجات الإنسانية. ( ز) التخطيط، ويعتبر التخطيط من أهم السمات التي يجب أن تعتمد عليها الدعوة الإنلامية.

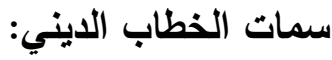

$$
\text { 2- } 1 \text { - الثمولية. }
$$

3- 3عايثة للأكة وقضايا الساعة.

$$
\text { 5- 5- الدق والصدق. }
$$

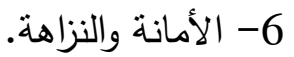

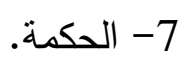

8- الثثابت - والأصول - والمتغيرات والمستجدات.

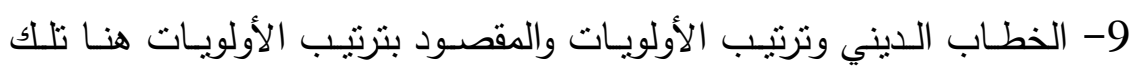

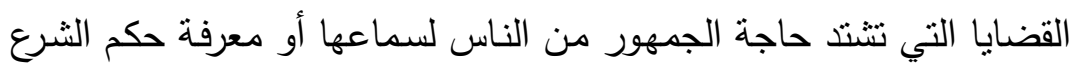
فيها أو تحليل جناياها. 
وقد تتعدد هذه الحاجات فالأمسة لها حاجـة، والبلد لها حاجـة، والقريـة لها حاجـة،

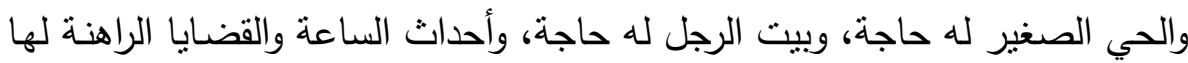
حاجة وهكذا.

ومسن الأمسور الجديرة بالملاحظـة في هذا الصـدد أن علمـاء الكـلام حينمـا أرادوا التدليل على وجود الله لجئوا إلى استخدام مقدمات منطقية بنطلق من التغير البادي

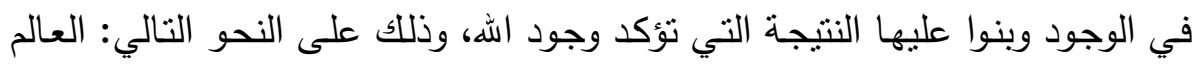
متغير - وكل متغير حادث، إذن العالم حادث، وهذه النتيجة جعلوا منها مقدمة أولى ولى ولى ولى في القياس المنطقي التالي: العالم حادث، وكل حادث لابد لله من محدث، إذن إن العالم لابد لله من محدث وهو الله.

والتجديد في الفكر الديني عمل يقوم به الإنسان الذي يرتاد الطريق لقومه فيرى ما

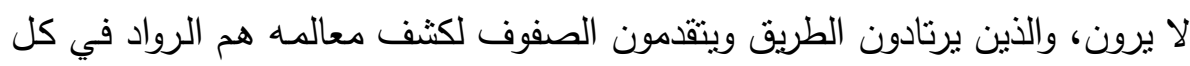

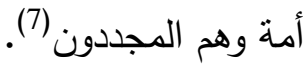
وتُعد قضية ضرورة تجديد الدعوة الإسلامية والقائمين عليها إنشكالية حقيقية، وأحد

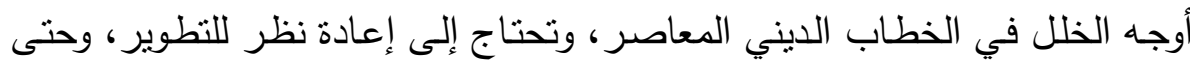
تتتاسب مع المجتمع المعاصر بتجلياته وتعقيداته العلمية والمعرفية، فلا تخطئ العين أن الغالبية العظمى من العاملين في حقل الدعوة من خريجي كليات الدعوة وغيرها

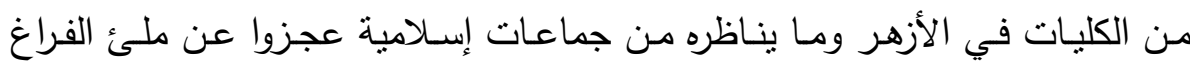
الديني لدى الجماهير ، واستقطابها بعيدًا عن الأفكار الخاطئة والغالبة.

والجدير بالذكر والملاحظ أن هناك الكثير من غير المختصين بالفكر الإسـامي ولا بقضايا الفقه والعقيدة، ونتيجة لعدم الفهم الحقيقي والمتكامل للإسلام تسارعت وتيرة

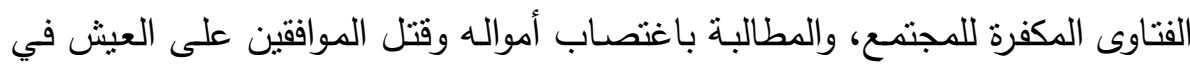

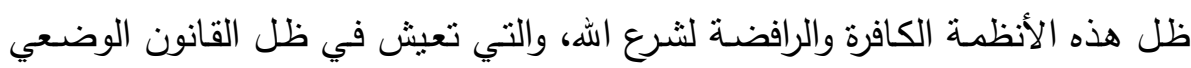
الغربي (8)

\section{ثانياً: مشكلة الاراسة:}

نظراً لوجود انقسامات داخل أفراد المجتمع المصري وذللك بعد ثورة يناير 2011م نجد أن هناك خلل واضح في الخطاب الديني وذلك لوجود ثنائية في الخطاب الديني 
نفسه أيضًا وارتباط الخطاب الديني بالسياسـة وأصبح كل فريق لـه اتجاهاته وآراءه

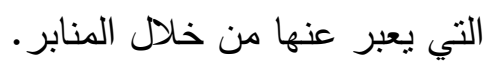
ولـذلك تتمثل مشـكلة الدراسـة في التعـرف على آراء واتجاهـات علمـاء الـدين

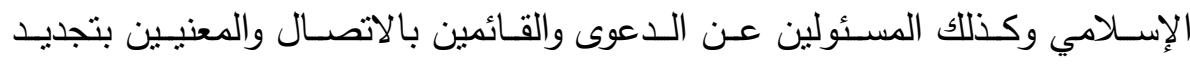

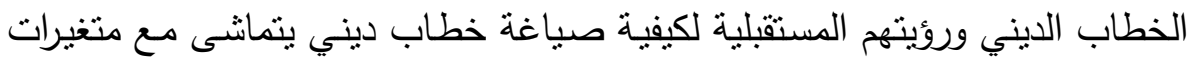

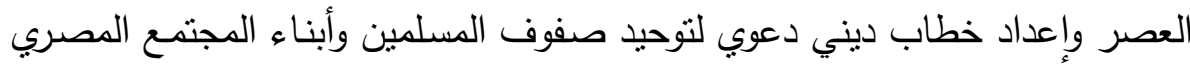

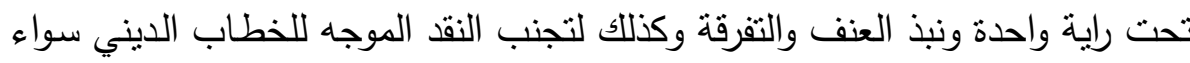

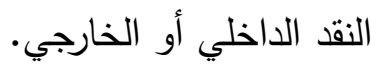
من هنا كانت مشكلة هذه الدراسة وهي التعرف على اتجاهات القائمين بالاتصال

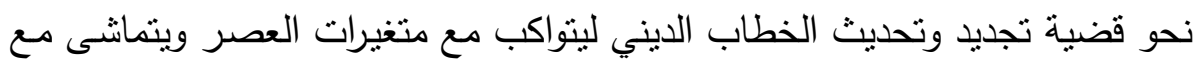

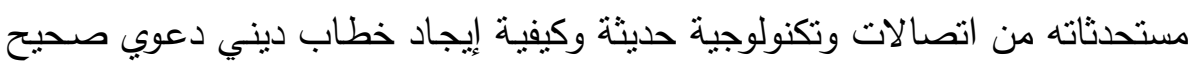

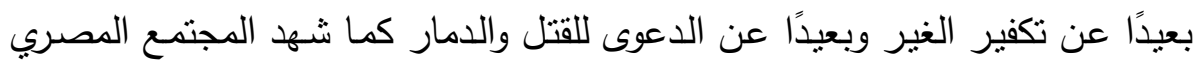

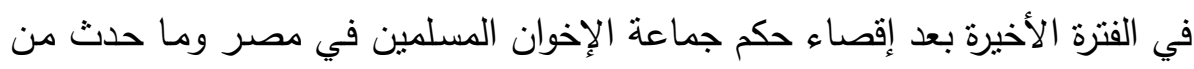

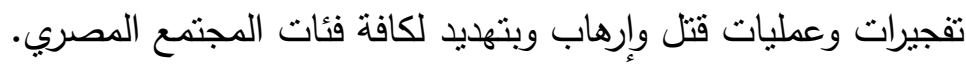
وضرورة إيجاد خطاب ديني متوازن لكل فئات المجتمع المصري خطاب يوجهـ

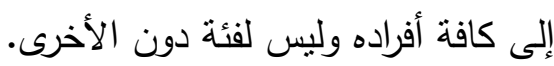

$$
\text { معنى الخطاب الإيني: للإر المعرفي }
$$

ويشير مفهوم الخطاب الدين إلى ذلك البناء من الأفكار والمعتقدات التي تتسم

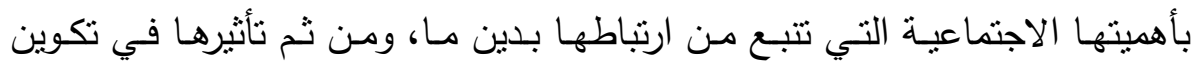
تصور فتلقي الخطاب من المؤمنين بهذا الدين عن العالم الذي يعيشون فيه وتحديد

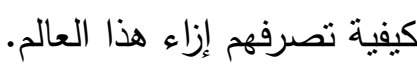

ومصطلح الخطاب الديني قد ينطوي على خطاب ديني مغلق وهو الخـاص

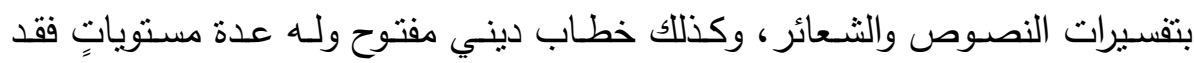

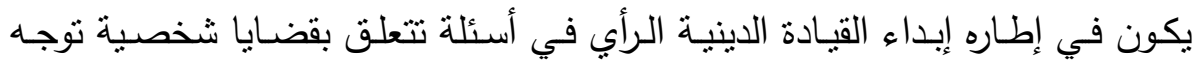

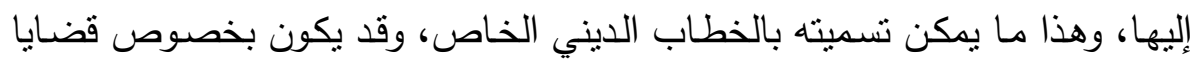


عامة مثل رأي الدين في الاقتصاد أو السياسة أو الهندسة الوراثية إلى أخرى وهذا ما

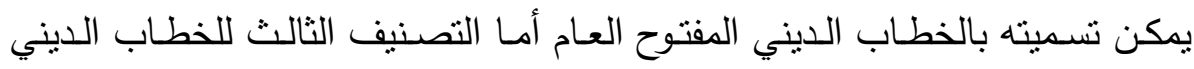

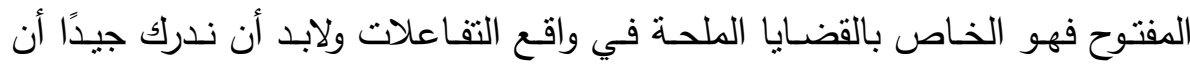

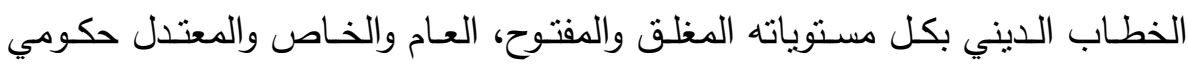

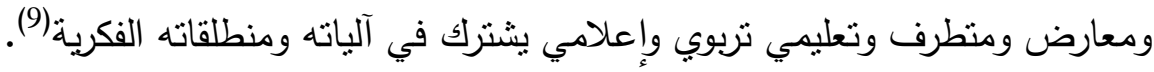

\section{مغنى التجديد الذي يجب أن تحمله رسالة " الخطاب الديني ":}

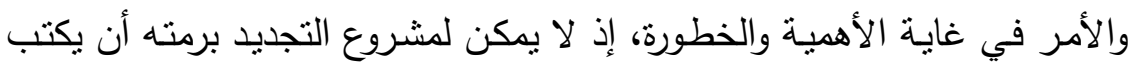

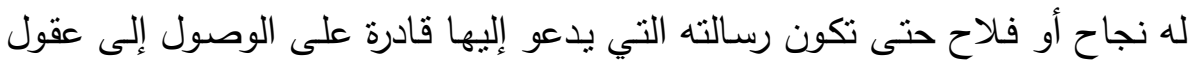

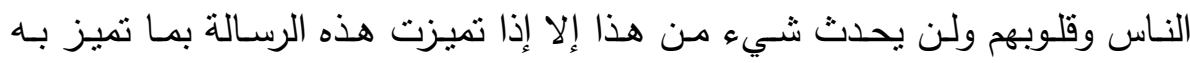
الإسلام نفسه في أول عهده ومبتدأ أمره. إن الأمر باختصار شديد ينحصر في ثلاثة أمورٍ (10): الأول: ويتعلق بالأمة أو المجتمع الإسلامي. الثاني: ويتعلق بالحكم والقضاء.

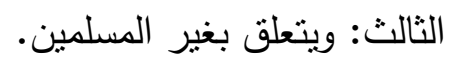

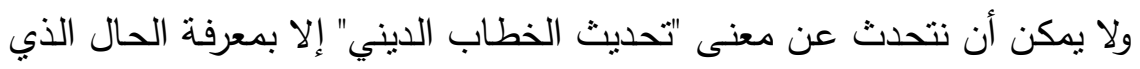

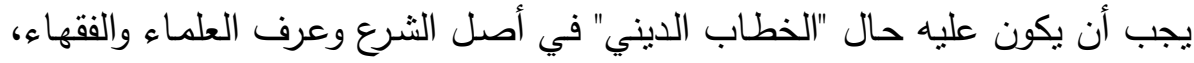

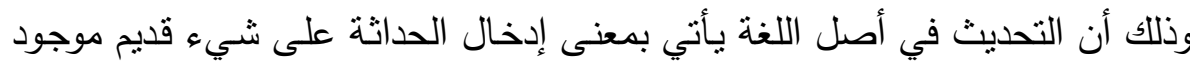

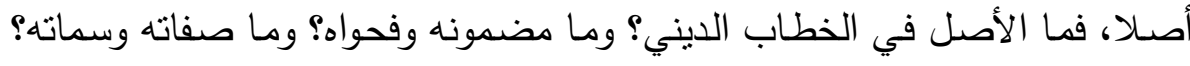

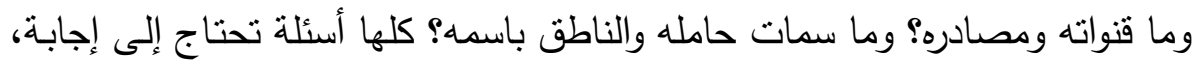

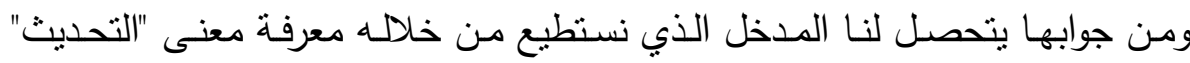
الذي بريد الإصلاحيون الدخلاء إدخاله على خطابنا الديني. ولا يمكن للخطاب الديني أن يبتعد في جوهره ومضمونه وفحواه عن الإسلام نفسه

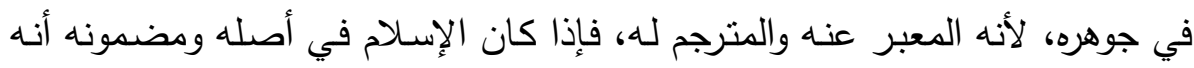

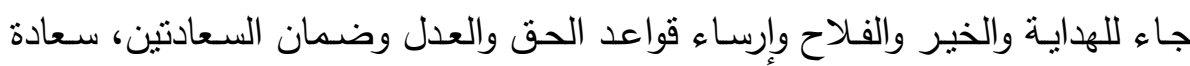

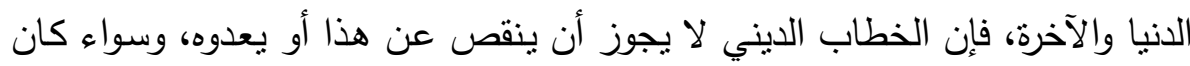

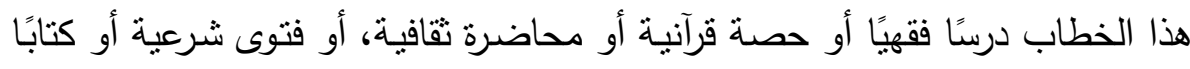


أو مقالة أو رسالة جامعيـة أو ندوة علمية أو خطبة في يوم جمعة أو عيد أو لقاء

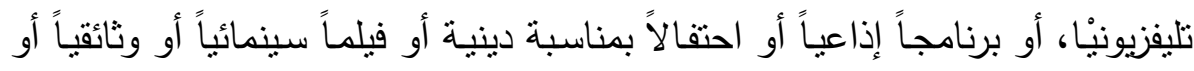

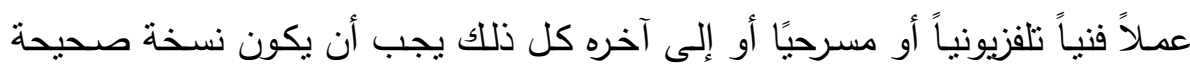

$$
\text { موثقة عن الإسلام نفسه (11). }
$$

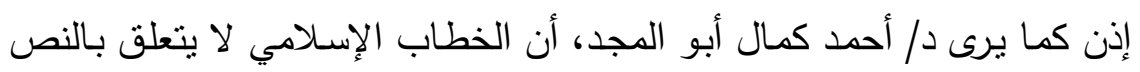

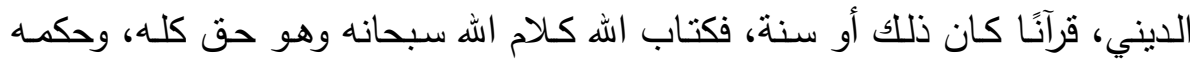

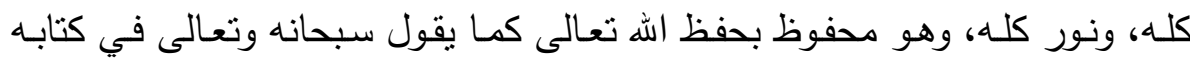

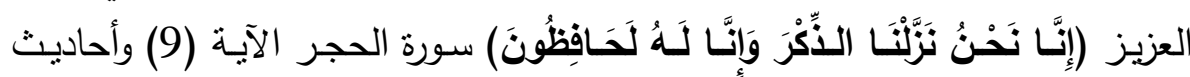

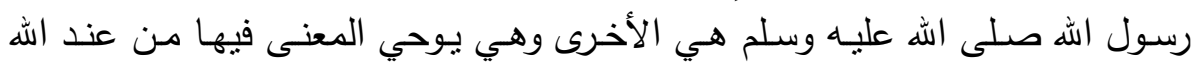
سبحانه واللفظ من عند رسول الله صلى الله عليه وسلم الذي أولى جوامع الكي الكلم.

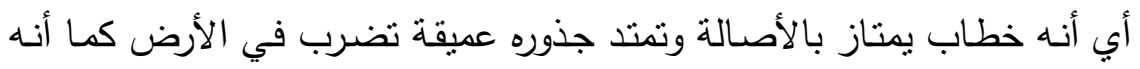

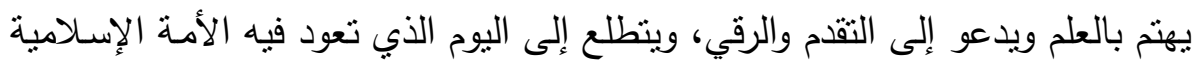
إلى ريادتها الني فقدتها في غفلة من الزمن (12).

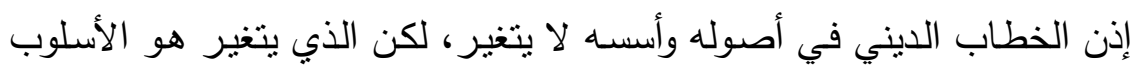

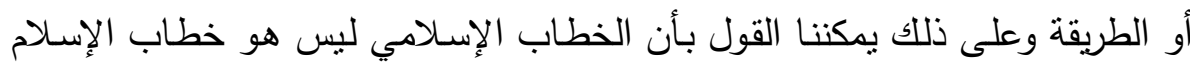

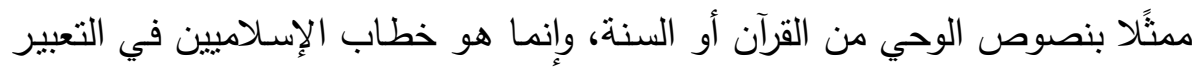
عن الرسالة التي يوجهونها إلى الآخرين في شأن من الثئون.

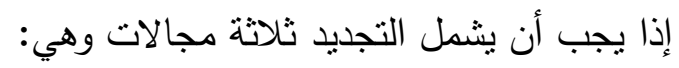

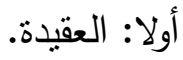

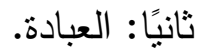

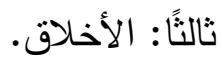

\section{أولاً: التجديد في مجال العقيدة :}

وذلك بتخليص العقيدة من الإضافات البشرية لتصبح نقية صافية ليس فيها أثر

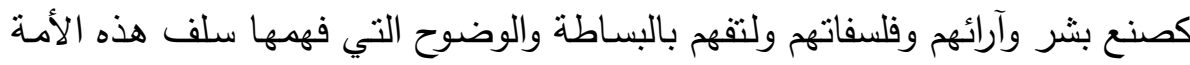

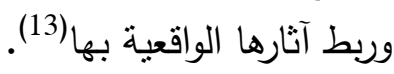




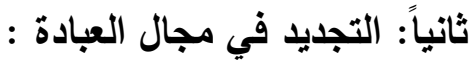

وذلك بييان مفهوم العبادة ومقاصدها في الإسلام من خلال الآتي:

( أ ) العبادة هي الغاية التي خلق الإنسان من أجلها:

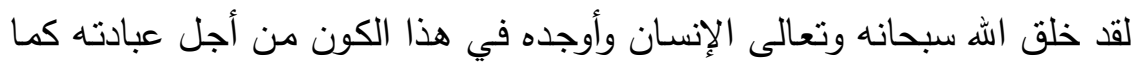

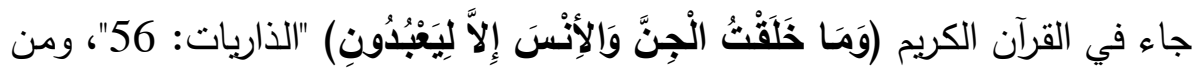

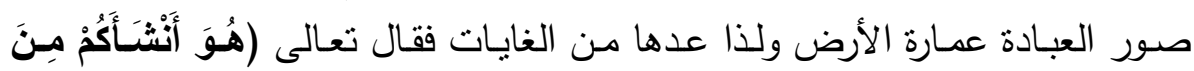

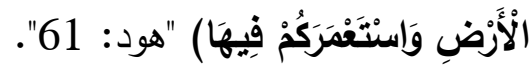

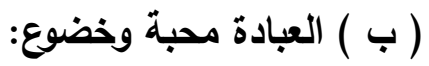

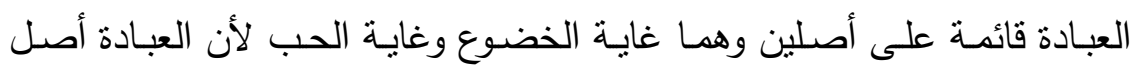

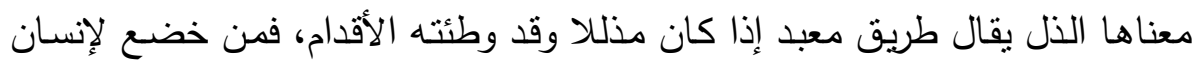

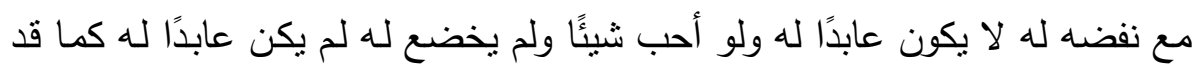

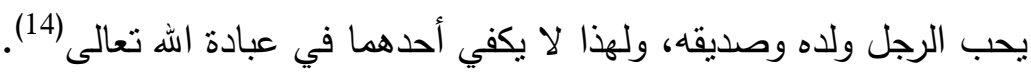
(ج) واجب التقيد بالشرع في العبادة: إن العبادة تتطلب التقيد بالشرع وعدم الوقوع في البدع والضـالات وتحليل الحرام

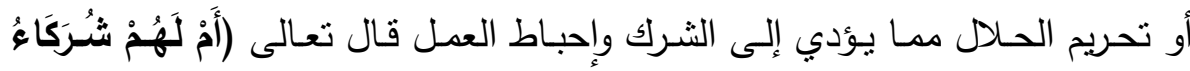

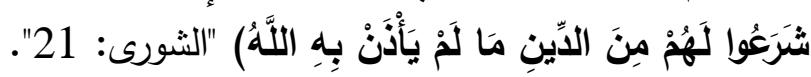
( ) ( العبادة في الإسلام شاملة لكل أمور الدين والدنيا:

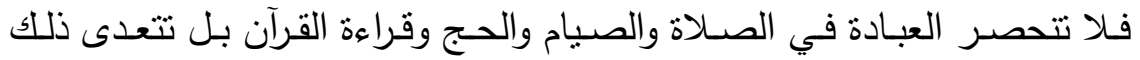

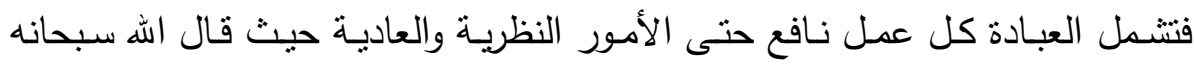

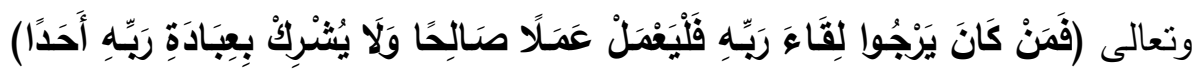

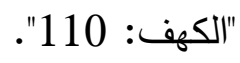

ففي الحديث عن أبي ذر أن ناستًا من أصحاب النبي صلى الله عليه وسلم قالوا

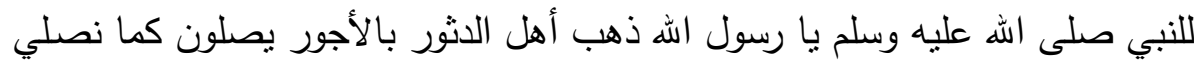

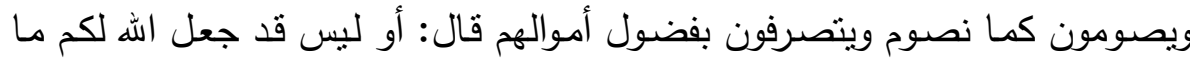


تقدمون إن بكل تسبيحة صدقة، وكل تكبيرة صدقة وكل تحميدة صدقة، وكل تهليلة

صدقة وأمر بالمعروف صدقة ونهى عن المنكر صدقة وفي بضع أحدكم صدقة (15). ثالثاً: التجديد في مجال الأخلاق والسلوك الفردي والاجتماعي:

لقد أصبحت الثـكوى مريـرة، لمـا أصـاب النـاس في العصسور المتأخرة وانهيـار الأخلاق واضطراب في الموازين، ومن هنا يتحتم على الدعاة والمجددين أن يتتبهوا لهذا الخطر وأن يبينوا للناس حقيقة ما هم فيه.

ونلاحظ ذللك في نصوص كثيرة من الكتاب والسنة ومن ذلك قوله صلى الله عليه

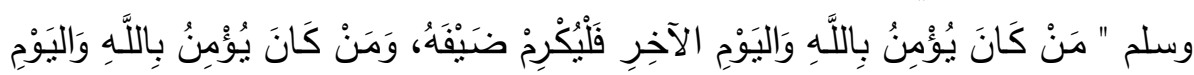

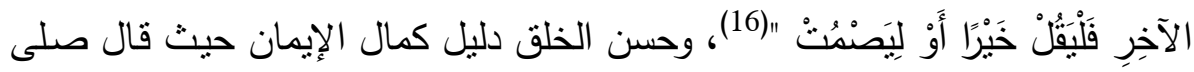

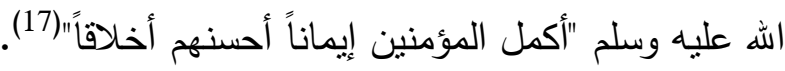
ومن أهم سمات الخطاب الإسلامي أيضًا - كما ينبغي أن يكون - ما يلي: 1- الدفع بالتي هي أحسن، قال تعالى (ادْفَعْ بِالَّتِي هِيَ أَحْسَنُ) سورة فصلت آية 34(18).

2- الدعوة بالحكمة والموعظة الحسنة، قال تعالى (اذْعُ إلََى سَبِيِلِ رَبِّكَ بِالْحِكْمَةِة

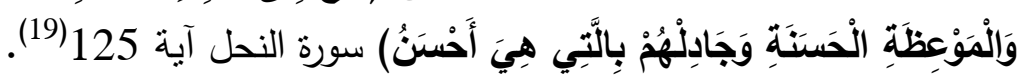

3- أن يكون الخطاب الإسـامي مراعيًا للزمان والمكان بحيث يكون لكل زمان

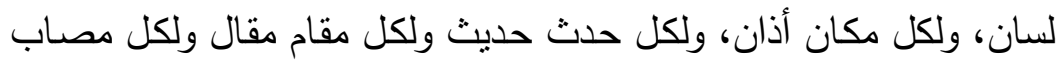
جواب، ولكل داء دواء، فالداعية الحق هو الذي يتتاسب خطابه مجال زلهاب زمانه

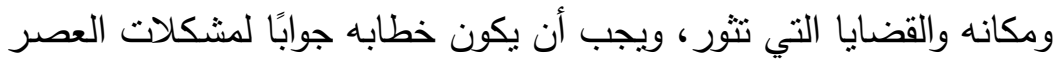
الذي يعيشه.

4- فهم المرحلة وفهم العصر وتحديد حاجاته والوقوف على سفن التغيير. 5- فهم المرحلة وفقه الواقع أصل معتبر في الثـرع يؤيده كتعبير القرآن عن حاجـات النـاس والمناسـبات ويؤكد تغييـر الفتوى بتغييـر الأزمنـة والأمكنـة

$$
\text { والأصول والعوائد (20). }
$$


6- أن يتراوح الداعية الحق بين الواجب والواقع وبين الثبليغ ومقتضيات العصر

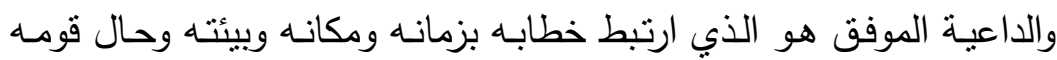

$$
\text { وأهله. }
$$

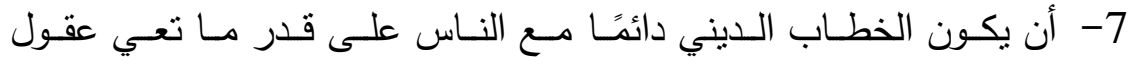

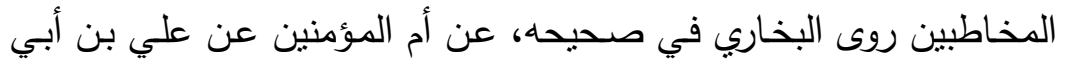
طالب قال حدثا الناس بما يعرفون، أنتريدون أن يُكذب الله ورسوله. 8- تحديد أهداف الدعوة العامة والأساسية والأهداف المرحلية. 9- ترتيب الأولويات بمعنى ترتيب ما هو أولى وما هو أدنى. 10- تكوين الرأي العام الجماهيري حول كل ما يهم المسلمون.

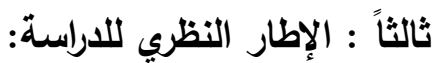

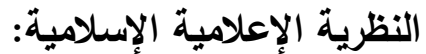

اعتمدت هذه الدراسة في بنائها النظري على النظرية الإعلامية الإسلامية حيث

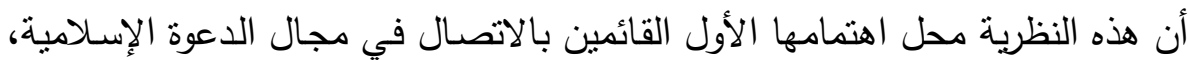

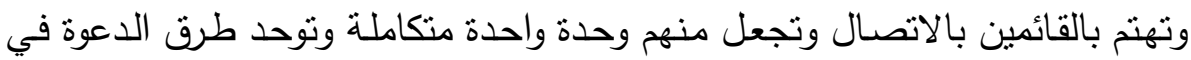

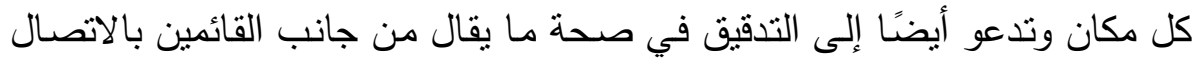
وكنلك تدعو المتلقيين للارسالة الإعلامية إلى إعمال العقل والتفكير فيما يقال. ومـازال آلاف البـاحثين منـُ القرن الأول الهجري وحتى الآن يقدمون الدراسـات

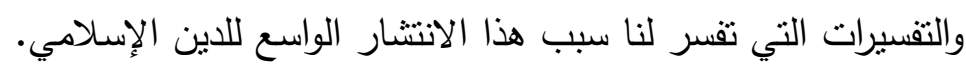
وعلى الرغم من شمول هذه الدراسات لأغلب الجوانب تقريبًا، إلا أن هناك جانباً

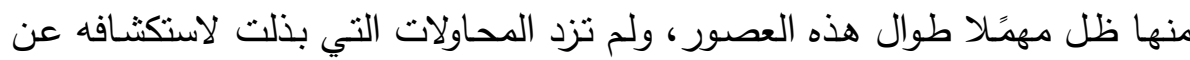

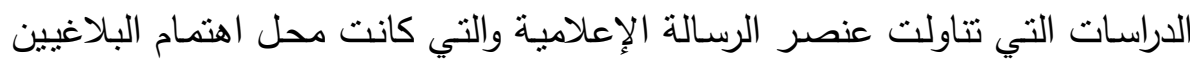
بالإضافة إلى بعض ملاحظات واستتناجات لكبار الأئمة الدعاة.

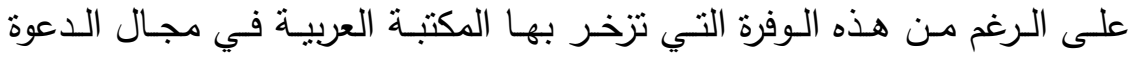

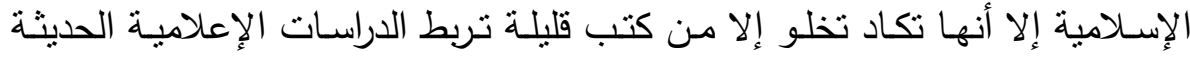
بأصول الدعوة الإسـامية، وتحاول أن تكثف لنا العطاء عن هذا البنيان المتكامل 
للنظرية الإعلامية الإسـلامية التي تضمن القرآن الكريم نظرياتها ونماذجها ومبادئها

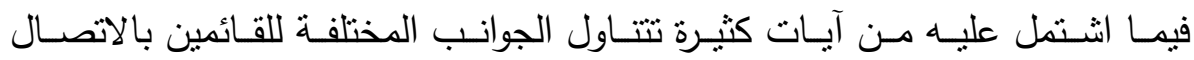

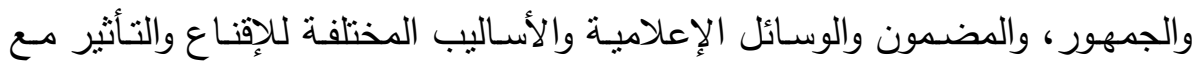

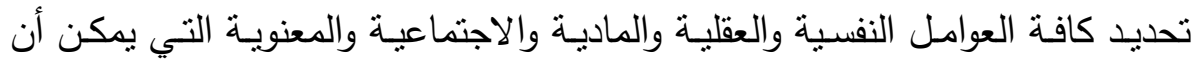
يكون لها تأثثر على عملية الإقناع سواء بصورة مبانشرة أو بصورة غير مباشترة. ولقد استوعب المصطفى صلى الله عليه وسلم مضمون هذه النظرية وصدر عنها

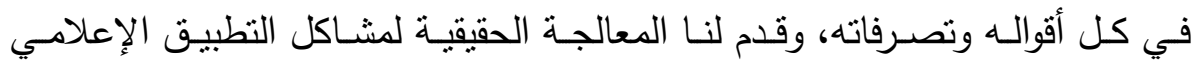

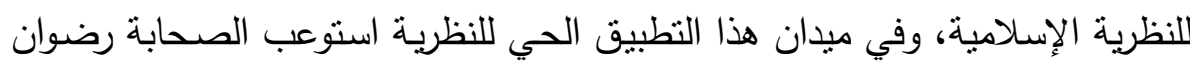

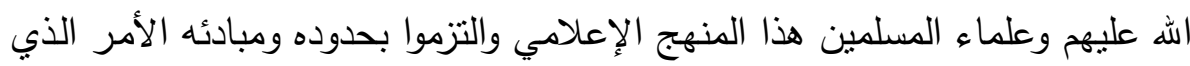

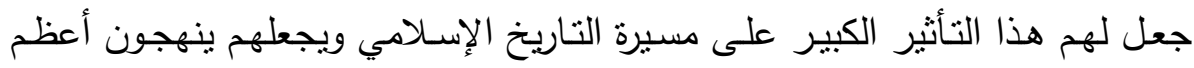

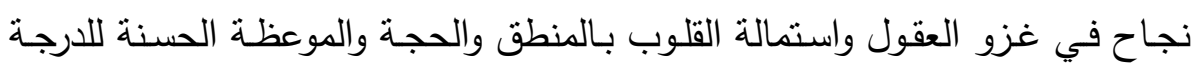

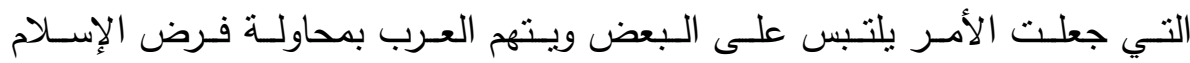
بالسيف (21).

ولم تنـتبعد النظريـة الإعلاميـة وجود أوعيات مـن القائمين بالاتصـال يسعون

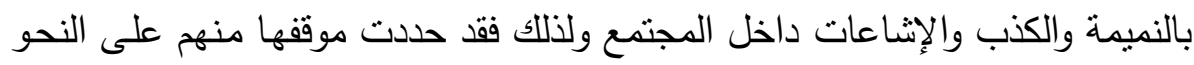
الآتي في جانبين (22):

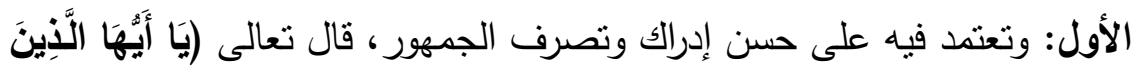

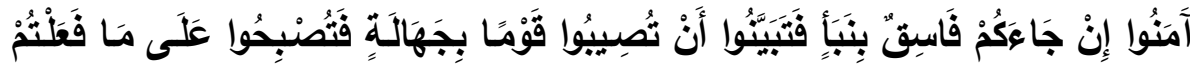

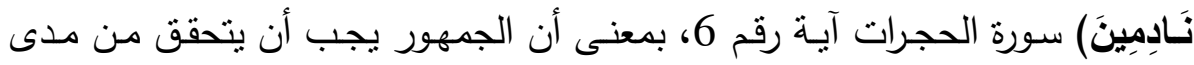
صحة هذه الأخبار ويدرسها جيذًا ليقف على أسبابها ومسبباتها ومدى صدقها لئها وكذبها. الثاني: فخاص بنشر الأخبار الكاذبة والثـائعات وموقف النظرية الإعلامية من

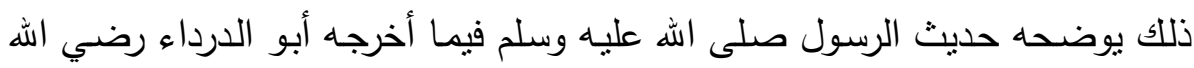

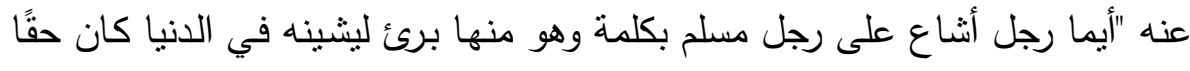

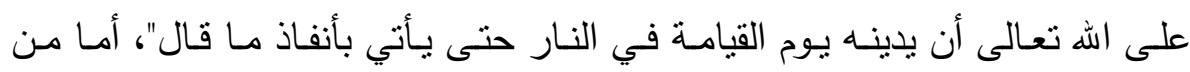

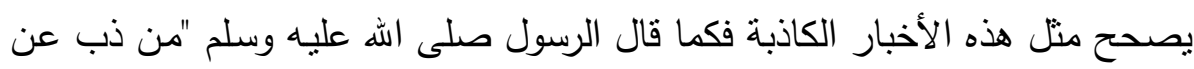
عرض أخيه بالغيبة كان حق على الله أن يقيه النار ". 
وأخيرًا فإن النظرية الإعلامية الإسـلامية جعلت من القائمين بالاتصـال أو الدعوة وحدة واحدة منكاملة منهم جميعًا ينهلون من منهل ثقافي واحد ويلتزمون بمبادئ واحدة بدعو إلبها القائم بالاتصال في الصين واليابان وروسيا وأمريكا وجنوب أفريقيا اليوم وغدًا وبعد ألف سنة، وهذه الوحدة العالمية تجعل من الدعاة مؤسسـة عالمية للدعوة

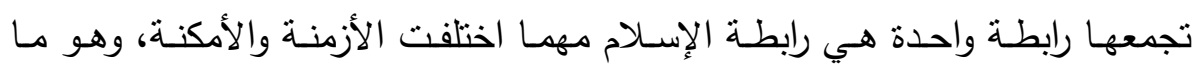
نطالب بـه الآن القائمين بالاتصال والمعنيين بتجديد الخطاب الديني في مصر حتى رلى

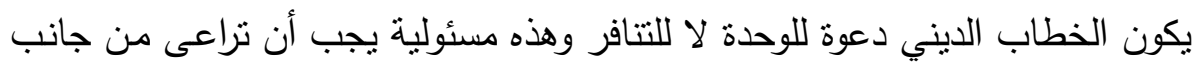
الأئمة والدعاة الذين هم المعنيين بدعوة المسلمين.

\section{نموذج الاتصال الأتي كأحد نماذج الاتصال الإسلامي :}

في هذا النموذج يتحول المستقبل في النموذج الأول إلى مرسل الرسالة الإعلامية

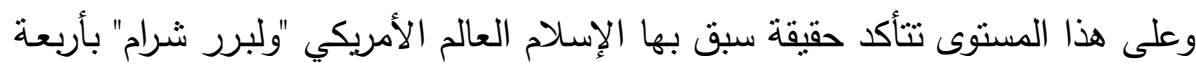

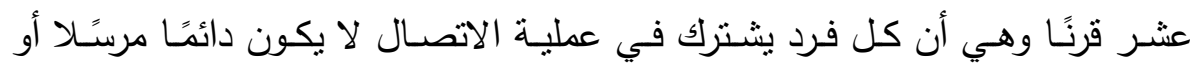

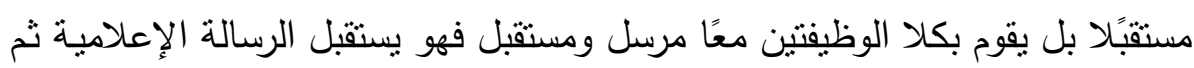
يقوم بعملية وضـع الفكر في كود أو رمز ثم يفلك كود مـا يتلقاه ومستقبل الرسـالة

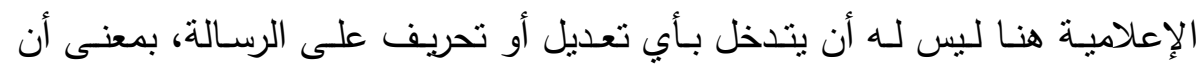

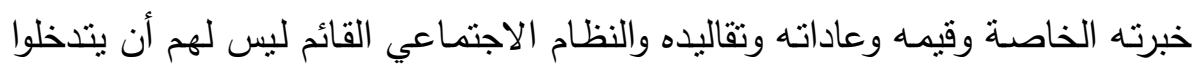
بأي شكل من الأشكال بتعديل أو تحريف الرسالة الإعلامية.

وإذا كان مستقبل الرسالة الإعلامية على مستوى النموذج الأول ليس سوى مجرد

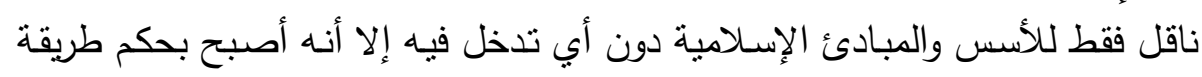
إعداده وتكوينه وكما فال رسول الله صلى الله عليه وسلم (أدبني ربي فأحسن تأديبي)

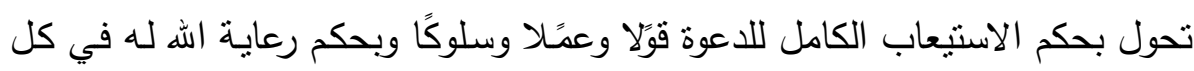

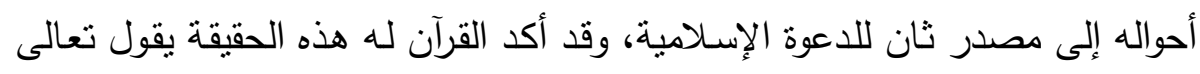

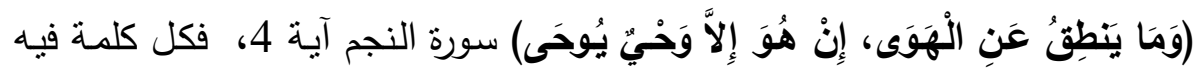

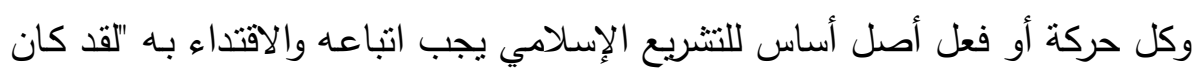
لكم في رسول الله أسوة حسنة". 


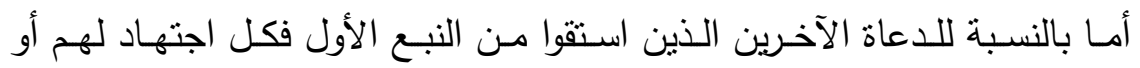

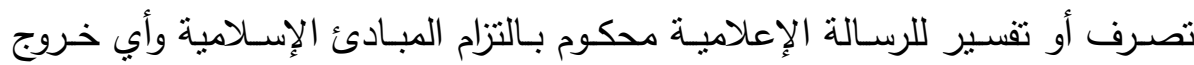

عنها يعرضها لرفض الجمهور لها.

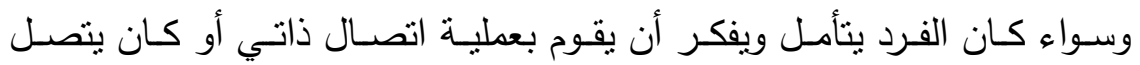

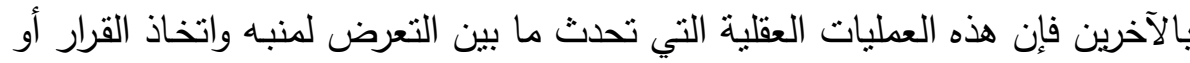

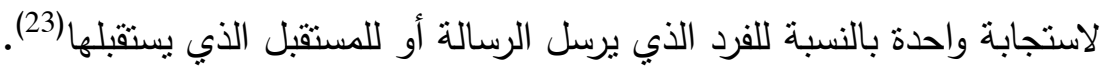
لذلك يجب ألا يخرج القائمين بالاتصـال مـن الأئمـة والدعاة عن نعليم الدين

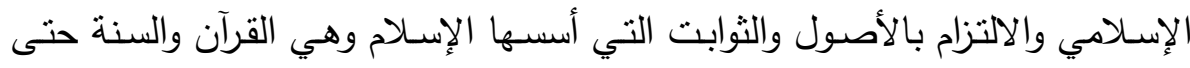
يكون الخطاب الديني متماسك ويدعو إلى وحدة المسلمين وتماسكهم ولا ينشر العنف والفرقة بين المسلمين بعضهم البعض.

\section{نموذج احتمالية إعمال العقل :}

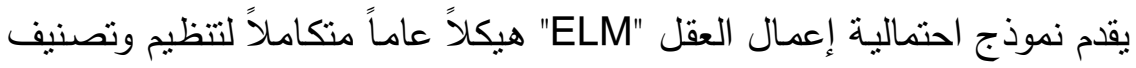

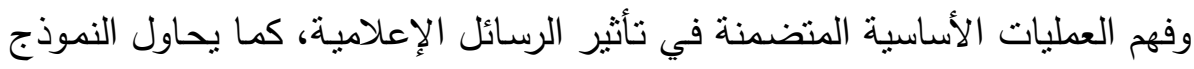

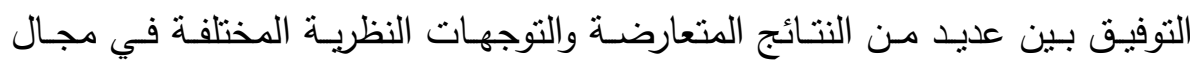
دراسات الاتجاهات تحت مظلة نظرية واحدة.

ويحدد النموذج عددًا من الطرق التي من خلالها يمكن لكل من المصدر والرسالة

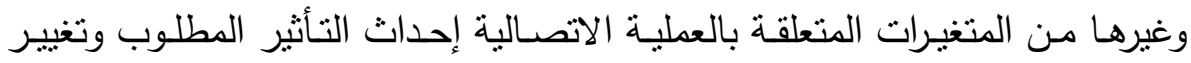

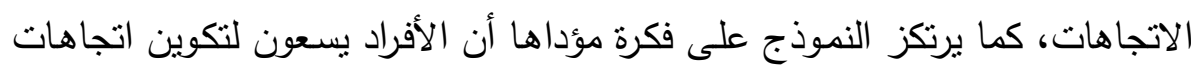

صحيحة(24).

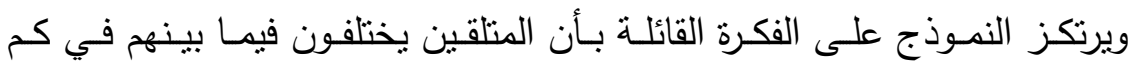

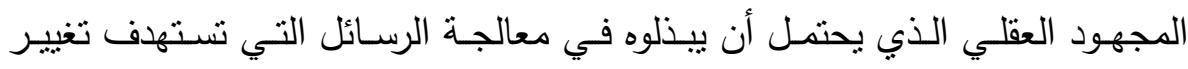

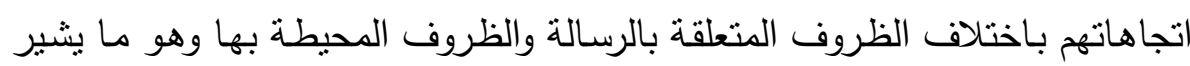

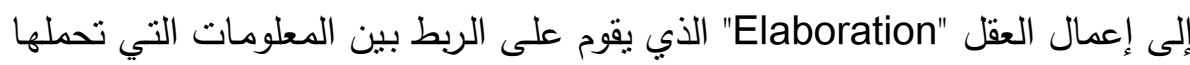

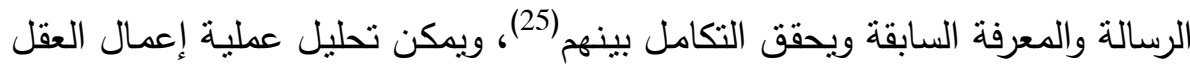

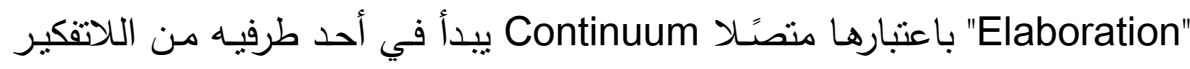

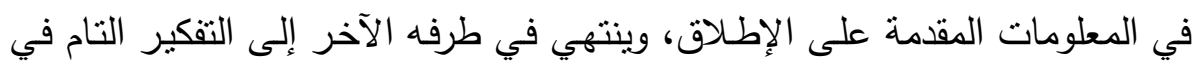


كل التفاصيل والجزئيات المتعلقة بالمعلومات المقدمة في الرسالة ودمجها في عقل الفرد في بناء معرفي (26).

\section{طرق تغيير الاتجاهات وفقًا للنموذج :}

ويفترض نموذج احتمالية إعمال العقل أن هناك طريقين لتغيير الاتجاه، أولهما:

Peripheral و الطريق المركزي Central route

.route

والأفراد الذين يتبعون الطريق المركزي يدققون في الأفكار التي يتعرضون لها

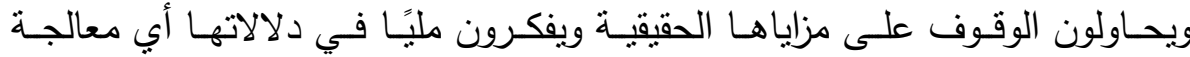
المعلومات الجديدة التي ينعرضون لها بأسلوب عقلانياني.

أما الذين يتبعون الطريق الهامشي فإنهم بسلكون طرقًا مختصرة لاتخاذ قراراتهم

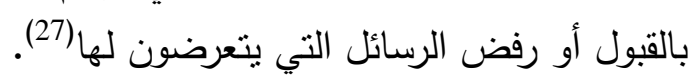

كما أن في نموذج إعمال العقل متغيرات منعلقة بالمصدر وذات نأثير منل:

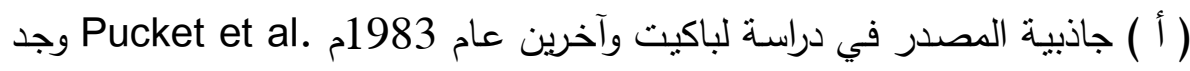

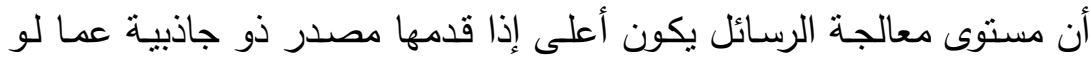

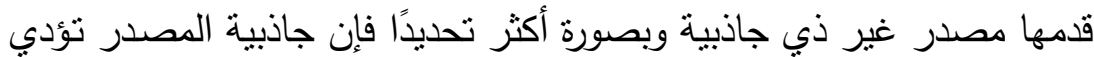

إلى الاقتتاع بالرسالة(28).

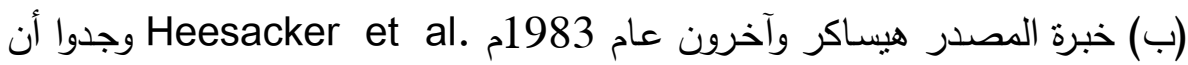
خبرة المصدر تجعل درجة أعمال العقل أكبر في الرسائل القوية وأن الرسائل

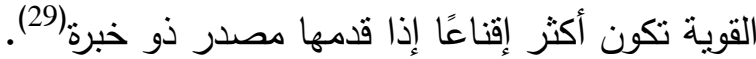

(ج) مصداقية المصدر Source credibility كما وضحها سميث وشيفر عام Smith and Shaffer 1995

الاعتقاد في مصداقية المصدر (30). 


\section{دراسة: يسري فهمي علي 2015م (31):}

تتحدد مشكلة هذه الدراسـة في البحث ودراسة دور الصحف الإسـامية في إمداد

الثباب الجامعي بالمعلومات الدينية والتي تسهم في تتمية الوعي الديني لديهم حيث يجب أن تكون الصحافة الإسلامية ذات دور فاعل ومهم في المجتمع.

وسـعت هـذه الدراسـة أيضًا إلى تحديد دور الصـحف الإسـلامية كمصدر مـن

المصادر التي تسهم في نتكيل وتتمية الوعي الديني لاى الثباب الجامعي بقضاياه.

وتتنمي هذه الدراسة إلى الدراسات الوصفية، واعتمدت الدراسـة على منهج المسح

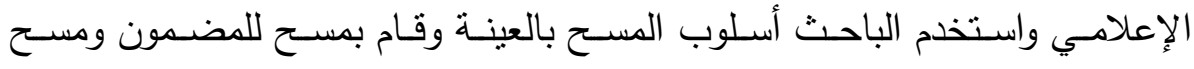
للجمهور

$$
\text { وتوصلت الدراسة إلى مجموعة من النتائج أهمها: }
$$

1- أن الموضوعات الدينية جاءت في مقدمة الموضوعات التي تتاولتها صحف

$$
\text { الدراسة بنسبة بلغت 57.3\% }
$$

2- الموضـوعات الدينيـة المتعلقـة بالعبـادات جـاءت في المرتبـة الأولـى بنسبة

$$
\text { .\%24.6 }
$$

3- الإلهيات جاءت في المرتبة الأولى بنسبة 48.9\% بالنسبة للموضوعات.

4- جاءت فئة الإيمان بالهه وموضوعاتها في المرتبة الأولى بنسبة 69.8\%.

5- جاء الإيمان بالرسل في مقدمة الموضوعات الدينية المتعلقة بالنبوات بنسبة

$$
\text { بلغت 58.8\%. }
$$

6- جـاءت السـلوكيات الإيجابيـة فـي مقدمــة الموضــوعات الدينيـة المتعلقـة

$$
\text { بالسلوكيات بنسبة 86.2\% 9 }
$$

7- جـاءت الأسـرة المسـلمة في مقدمـة الموضـوعات المتعلقة بالأسـرة والأحـوال

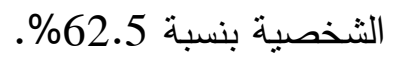


8- هناك إقباًلا ملحوظًا بين المبحوثين على قراءة الصحف الإسلامية مما يشير إلى أن الصحافة الإسلامية هي الأكثر استخدامًا من عينة الثباب الهاب الجامعي. 9- دافع الثباب للتعرض إلى الصحف الدينية هو الإمداد بالمعلومات الدينية مما يدل على حاجتهم الثنديدة للنوعية الدينية ولمزيد من الوعي الديني.

دراسة باكينام حسن غراب 2013م (32):

تمثلت مشكلة الدراسة في أن هناك ثمة اختلافات بين التيارات السياسية والفكرية

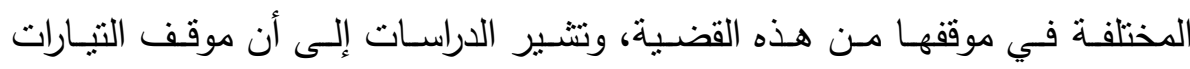

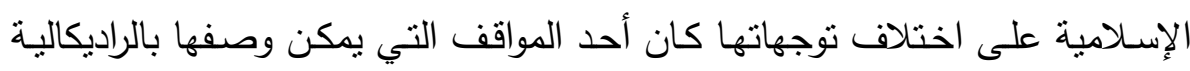
من هذه القضية حيث غلب على معظم التيارات الإسلامية موقف عدائي منتيدد تجاه هذه القضية.

وتسعى هذه الدراسة إلى تحليل وتأصيل ذلك الموقف لتحديد الثأثيرات المتبادلة

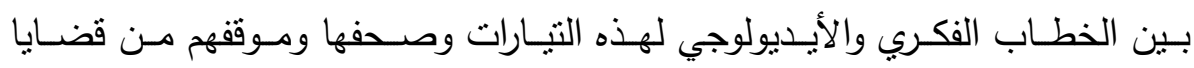

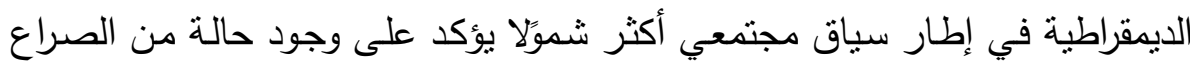

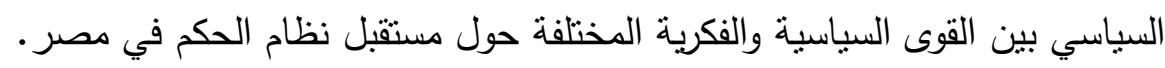
وهدفت الدراسـة إلى رصد وتوصيف وتحليل الملامـح العامـة لسياسـات تحرير

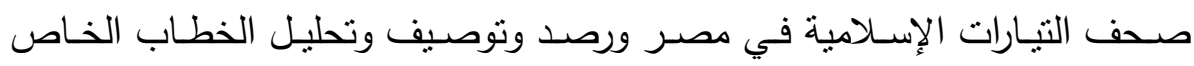

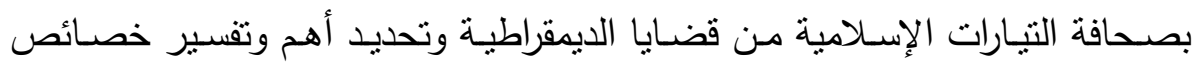

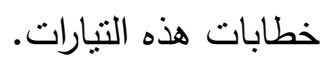

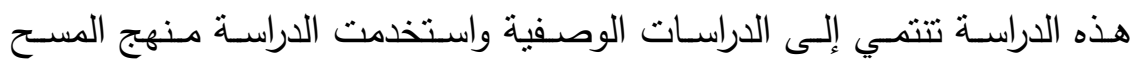
الإعلامي والمنهج المقارن استخدمت أدوات منها مسار البرهنة والقوى الفاعلة والأطر العرد

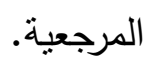

\section{دراسة: حنان محمد عبد المجيد 2013م (33):}

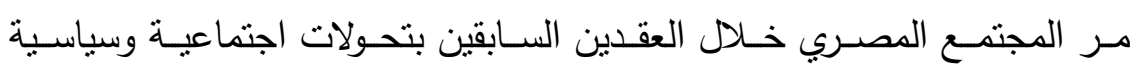

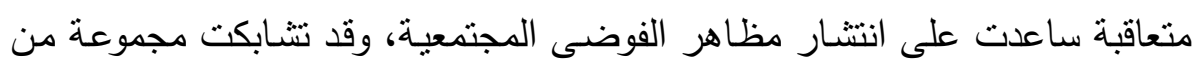

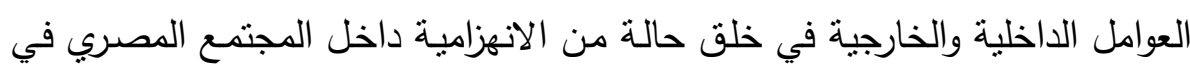


ظلـل غيـاب المشـروع القومي وتشـويه البنيـة الاجتماعيـة واضـطراب منظومـة القيم

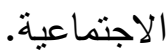

لذللك تنتلت مشكلة هذه الدراسة في الفوضى المجتمعية وانعكاساتها على فوضى التهى الخطاب والإفناء الديني بين القنوات الفضائية والمواقع الإليكترونية. هذه الدراسـة تنتـي إلى الدراسـات الوصفية حيث تهتم بالتحليل الكيفي لأبعاد وتأثثرات ظاهرة الفوضى في المجتمع المصري. واستخدمت الدراسة أسلوب البحث المكتبي النظري، كما تعتمد على تحليل نتائج

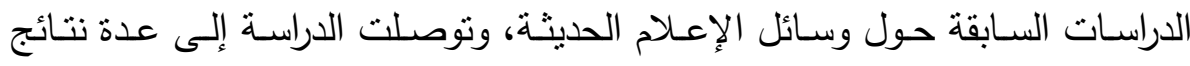

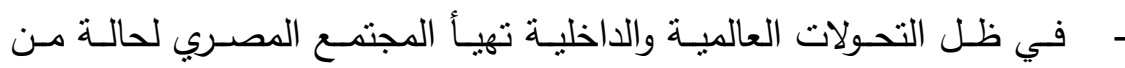
الفوضى المجتمعية وفي إطار هذه الفوضى ظهرت موجة جديدة دينية شارك الفي في صنعها مجموعة من الدعاة الجدد غير مؤهلين.

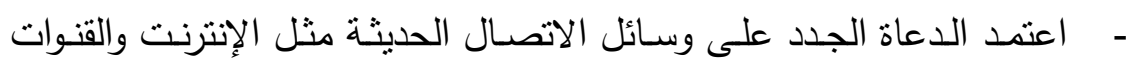

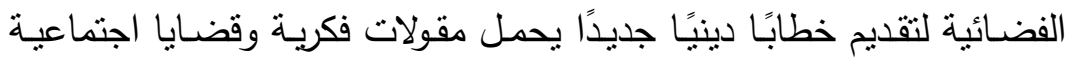

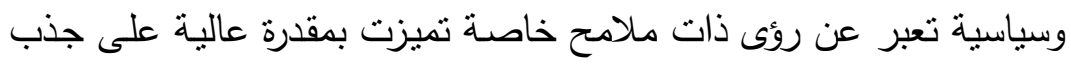
· الجماهير

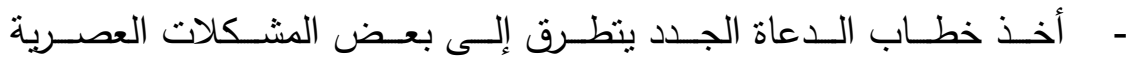

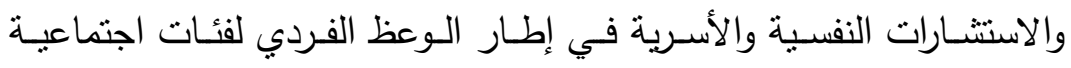
معينة. - - مساهت القنوات الفضـائية بثكل مبانشر في انتشـار الفوضى في الخطاب الديني الجديد. - حدث تحول جوهري في مضمون الخطاب الديني المقدم من الدعاة الجدد

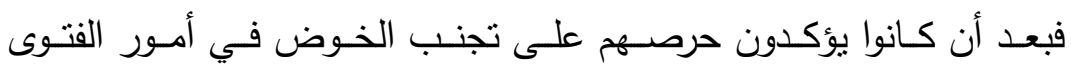

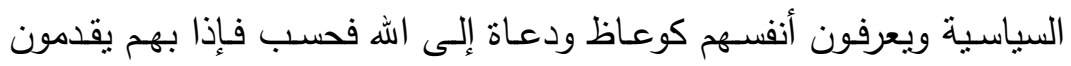
الفتاوى دون الاستتاد إلى قاعدة شرعية ويتعرضون للأكمور السياسية في في لفي

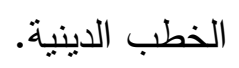




\section{دراسة: عبد الحكم أبو حطب 2012م (34):}

تهدف الدراسة إلى تحقيق هدف عام يتمتل في التعرف على رؤية كل من علماء

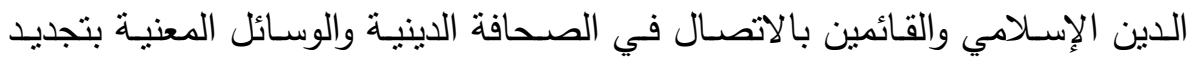

الخطاب الديني في الصحف الدينية.

واستخدم الباحث الدنهج الوصفي التحليلي وتتبثق أهمية هذه الدراسة في ما يلي: 1- إن تجديد الخطاب الديني في الصحف الدينية المصرية ضروري في كل وقت ومتجدد دائيًا.

2- تعرض عالمنا المعاصر لتبارات فكريـة متعددة أتاحت لها وسـائل الإعـام

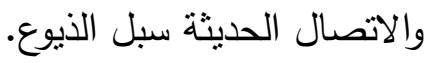
3- الحاجة إلى تجديد الخطاب الديني.

وتوصلت الدراسـة إلى مجموعـة من النتائج والتوصيات ومنها أن أهم ضـوابط

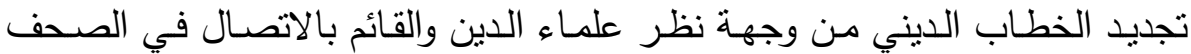
الدصرية هو أن بنطلق فكر التجديد من القرآن الكريم والسنة النبوية أوَّلا ثم القياس التياس

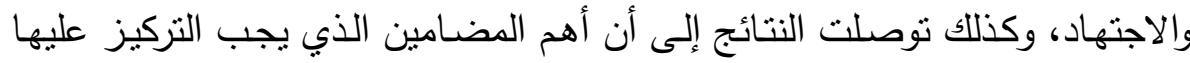
المضامين المنعلقة بالقيم الإيجابية لدى أفراد المجتمع وحفظ الوطن والحفاظ عليه.

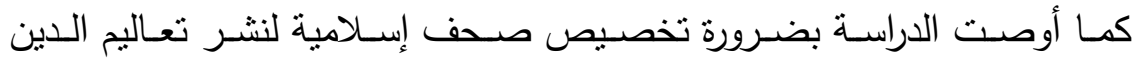
الإسلامي ببساطة ويسر مع ترجمة مضامينها إلى كل اللغات، وكذللك ضرورة إبراز

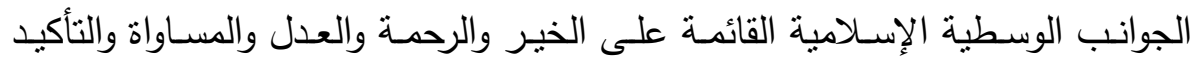
على أن تطوير الخطاب الديني لا يعني السساس بثوابت الدين.

دراسة: علي حمودة جمعة سليمان 2011م (35):

تمتلـت مشـكلة الدراسـة في أن شـبكة الإنترنـت قدمت الفرصــة لنثـر الـدعوة الإسلامية من خلال نشر تعاليم الدين الإسلامي والثقافة الإسلامي بالإضافة إلى إلى أنها

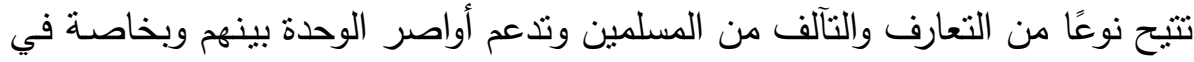

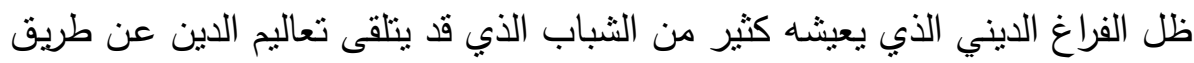

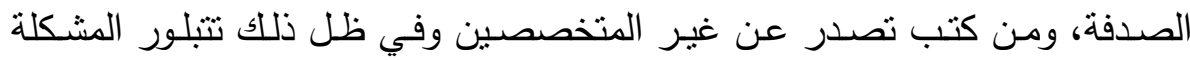


البحثية في "مدى تأثير الثباب الجامعي بالمحتوى المقدم من خـال شبكة الإنترنت

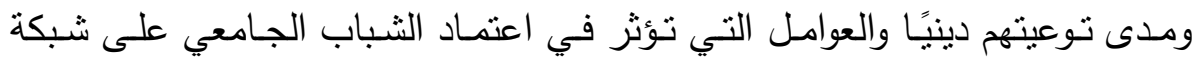

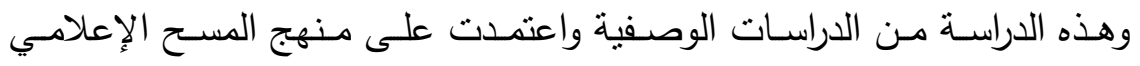

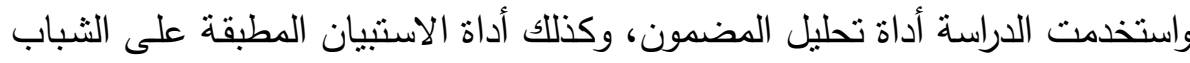

الجامعي.

وتوصلت الدراسة إلى مجموعة من الننائج أهمها:

1- احتلت الموضوعات الدينية في اهتمامات المواقع بنسبة 51.7\% ثم المبات احتلت

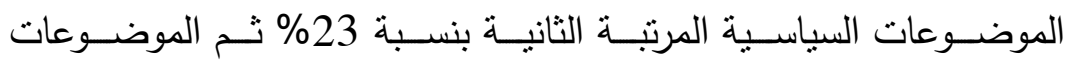

الاجتماعية من حيث اهتمام الموقع بنسبة 8.2\%.

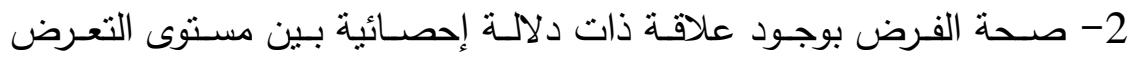

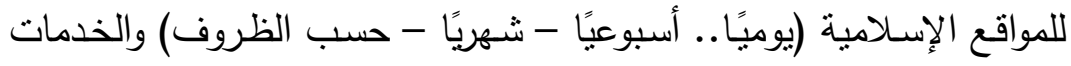

التي يستقيد منها المبحوثين في المواقع الإنسلامية.

3- عدم صحة الفرض بوجود علاقة ذات دلالة إحصائية بين درجة الاستفادة

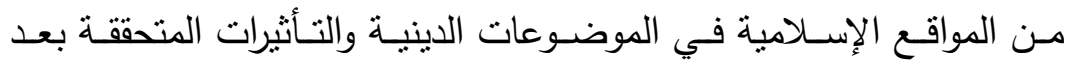

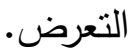

4- تصحيح اعتقاد القائين بالاتصال في مجال الدعوة لطغيان الصورة الذهنية

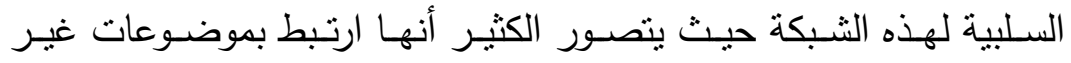

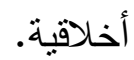

دراسة: حسام محمد إلهامي 2010م (36):

تهدف الدراسة إلى البحث والكثف عن أبرز ملامح ومكونات الخطاب الإعلامي

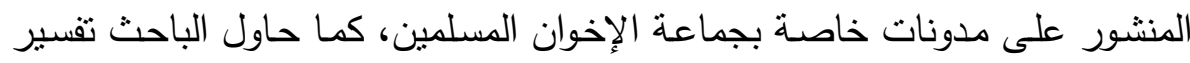

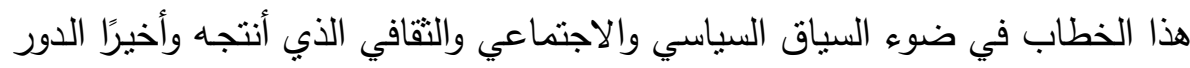
الذي لعبته سمات الوسيلة الاتصالية في تتكيل ملامحه أيضًا. 
واعتمـدت الدراسـة على تطبيـق منهجيـة التحليـل الكيفي للخطـاب، وعلى وجـهـ التحديد أسلوب التحليل النقدي وبينتد التحليل النقدي للخطاب إلى روئية وظيفية للغة لنة تحاول أن ترصد الوظيفة الاجتماعية للنصوص اللغوية المدروسة. وكانت أبرز مكونات وملامسح الخطاب المنشور على مدونات الإخوان المسلمين

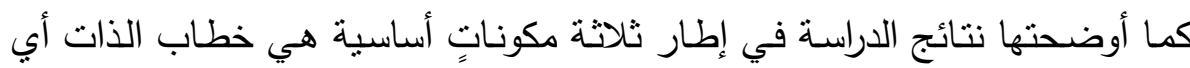
الخطاب المتعلق بجماعة الإخوان المسلمين، ثم يليه الخطاب المتعلق بـالآخر وهو إنو الخطاب المتعلق بالطرف الخصم في معادلة الصراع السياسي وهو في هذه الحالة السلطة السياسية الحاكمة ثم خطاب الواقع وهو موضوع الصراع بين الذاتية والآخر . وأخيرًا كشفت الدراسة عن أن المدونات شكلت سبيًالا لأعمال وتطبيق النقد الذاتي للحركة من جانب أطراف جديدة لم يكن مسموحاً لها بممارسة هذا النقد في الإطلار التنظيمي للحركة.

\section{دراسة: نجلاء محمود المصيلحي 2009م (37):}

تمثل مشكلة الدراسـة في موقف الخطـاب الإسـلامي من العمليات التتمويـة في

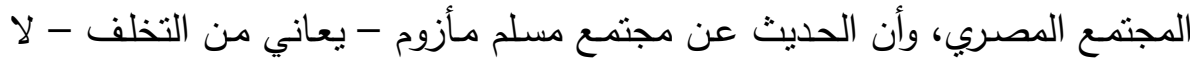

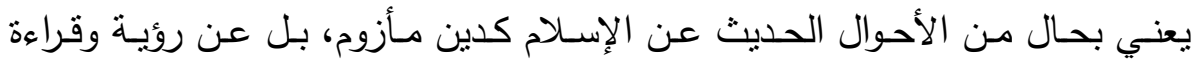
مأزومة للإسبلام.

وموضوع الدراسة هي محاولة لإلقاء الضوء على الخطاب الإسـامي في مصر

وعلاقته بالتتمية التي تتمنل في أبعادها السياسية والاقتصادية والاجتماعية والثقافية. كما تهدف الدراسة إلى الكثف عن العلاقة ما بين الخطاب الإسـلامي في جانبه

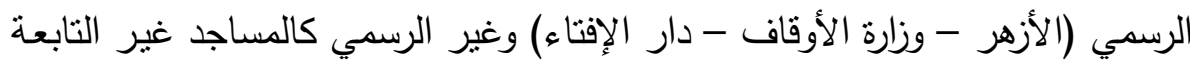

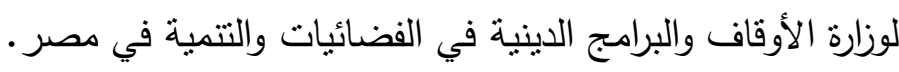

ولجأت الدراسة إلى تحليل المضمون الكمي والكيفي، كما استخدمت الدراسـة أداة تحليل المضمون لعدد 136 خطبة في كل من الجامع الأزهر وبعض مساجد القاهرة وتحليل مضمون مجلة الأزهر وكذلك تحليل مضمون (51) حلقة من البرامج الدينية،

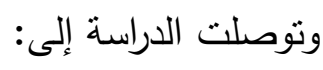


1- انخفاض مستوى الاهتمام بالموضوعات الدتعلقة بالاقتصاد عمومًا ويميل

إلى الاغتراب عن الواقع الاقتصادي وتجاهل الخطاب للعديد من القضايا

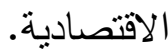

2- أكد الخطاب على الكثير من القيم التي تؤسس مكارم الأخلاق لأنه لم يول

عناية لذلك الجانب القيمي الدافع للتغيير والتقدم.

3- فقد تأثر الخطـاب الإسـلامي بـالظروف الدوليـة والضـغوط الخارجيـة التي

تمارس على الدول الإسلامية في السنوات الأخيرة.

دراسة: صالح السيد العراقي 2006م (38):

تشكلت في هذه الدراسة مشكلتها أنها سعت إلى التعرف على أهم أساليب نطوير

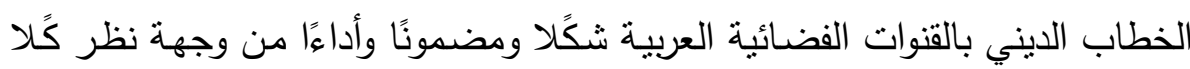

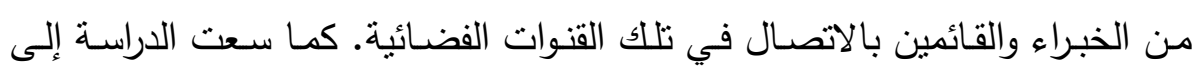

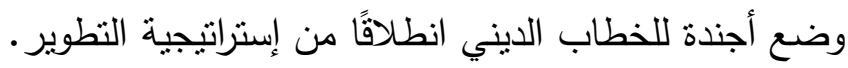

المنهج المستخدم في هذه الدراسة هو منهج المسح الإعلامي الميداني المطبق

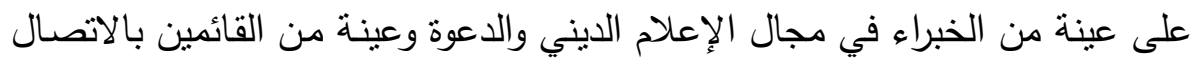

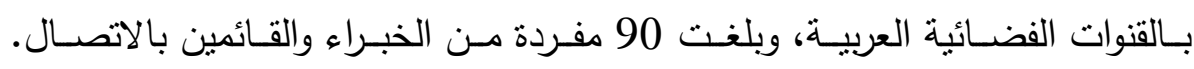
واستخدت الدراسة أداة الاستيان بالمقابلة مع القائمين بالاتصال. وتوصلت الدراسة إلى مجموعة من النتائج منها:

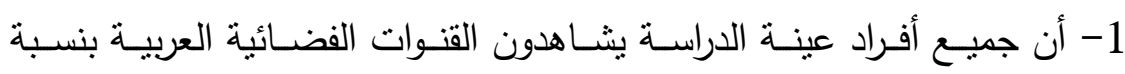

$$
\% 100
$$

2- أن نسبة 76.7\% مـن أفراد عينـة الدراسـة بثـعرون بالرضـا عن الخطـاب

$$
\text { الديني في القنوات الفائية. }
$$

3- شكل عدم قدرة الخطاب الديني على إظهار جوهر الدين الإسلامي الصحيح

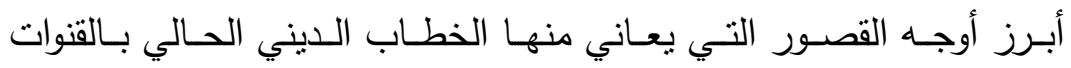

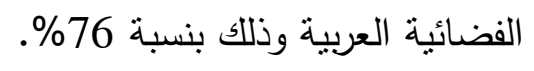


4- أهم ضوابط تطوير الخطاب الديني يتمثل في أن ينطلق فكر النطوير من

القرآن والسنة النبوية ثم اجتهاد العلماء.

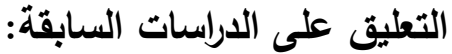

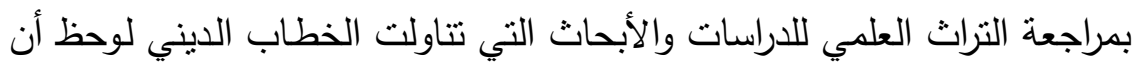

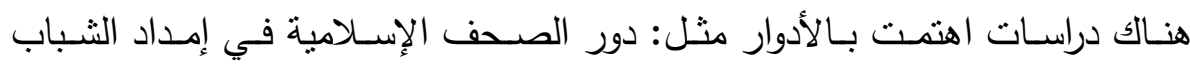

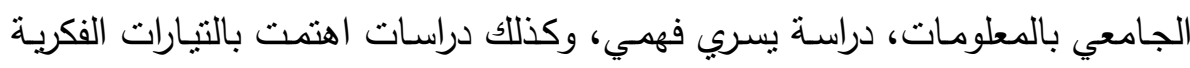
والسياسية والتأثيرات المتبادلة للخطاب الديني، ودراسات اعتمدت على التئي البحث المكتبي

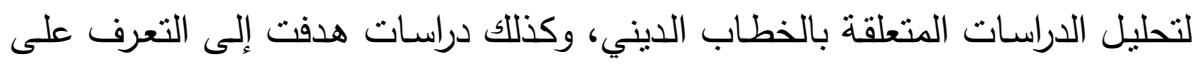

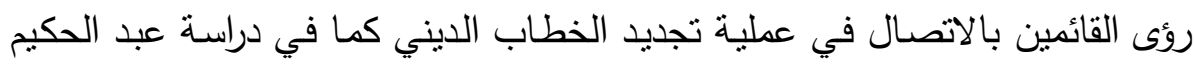

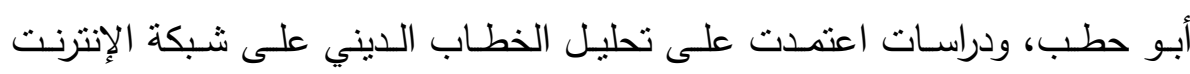

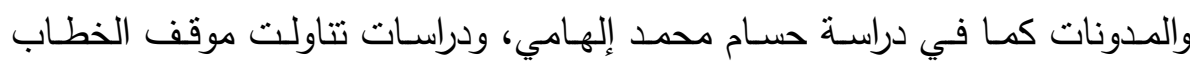

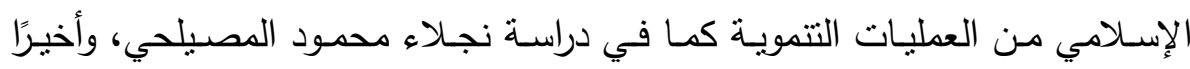

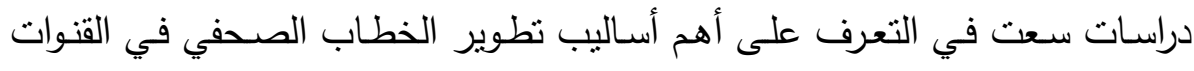

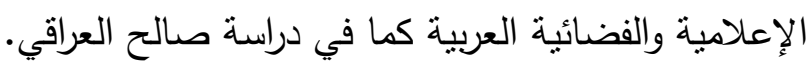

ونحن في هذه الدراسة نتـاول تجديد الخطاب الديني من رؤى ووجهات نظر

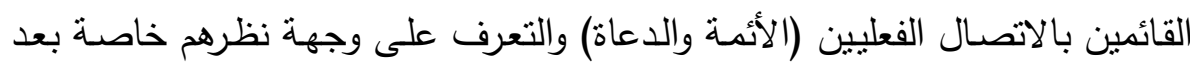

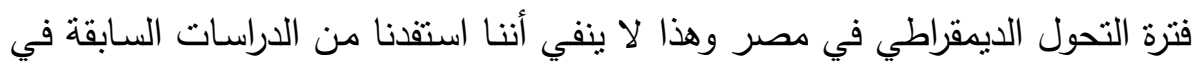
الإعداد لهذه الدراسة والتعرف على الإطار الدنهجي للاراسات الأخرى.

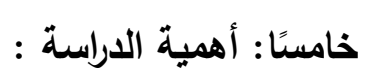

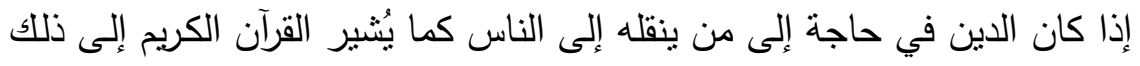

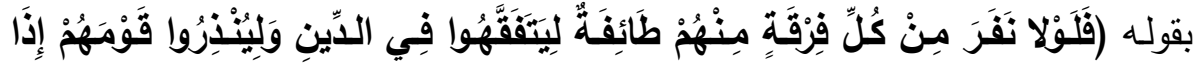

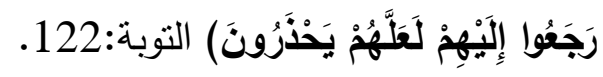
فإن أسلوب الخطاب الديني لابدـ أن يكون مواكبًا للمتغيرات الحياتيـة وملائئًا

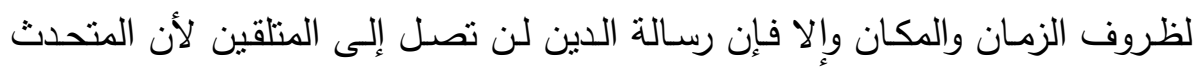

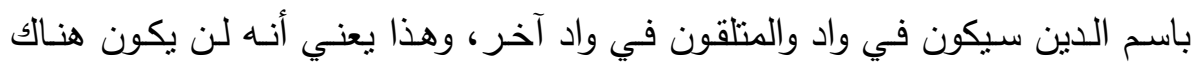
تجاوب أو تفاعل بين الجانبين وبذللك يفقد الخطاب الديني معناه ونأثيره. 
ويتضح من ذلك أن تجديد الخطاب الديني يعد ضرورة حياتية واجتماعية ودينية

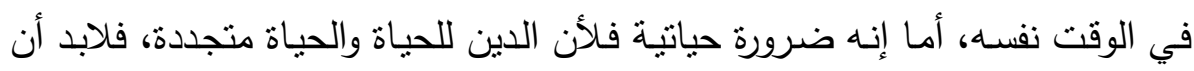

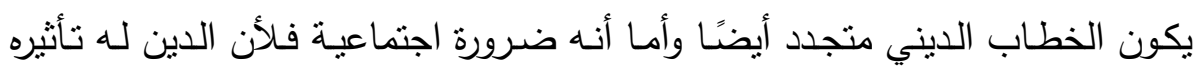

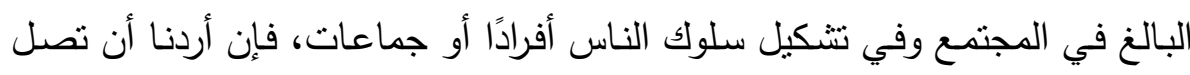

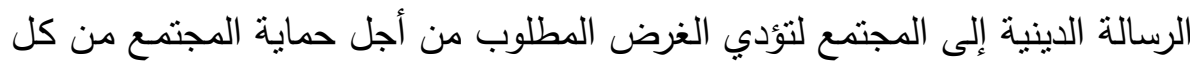
أنكال التشدد والنطرف والإرهاب فلا مفر من تجديد الخطاب الديني.

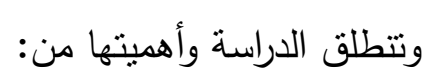

1- الحاجة الضرورية إلى تجديد الخطاب الديني بعد فترة التحول الديمقراطي

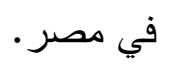

2- ظهور بعض الاتجاهات الدينية المتعارضة مع صحيح الدين.

3- انتشار بعض مظاهر التطرف والإلحاد بين الثباب في المجتمع المصري.

4- الثنائية الدينية في المجتمع المصري بعد زوال حكم الإخوان.

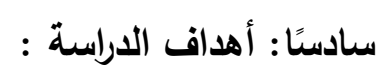

الدراسة تحاول جاهدة إلى تحقيق وضرورة تجديد الخطاب الديني المعاصر بما

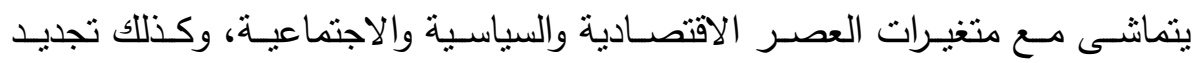
الخطاب الديني بما ينمانشى مع وسائل وتكنولوجيا الاتصال التصني الحديثة. هذا بالإضافة إلى مجموعة من الأهداف الأخرى منها:

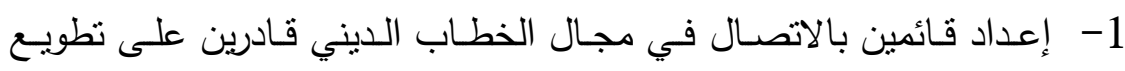

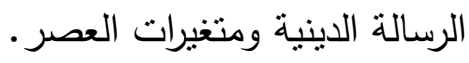

2- وضـع تصور من جانب القائم بالاتصـال لكيفية وضرورة تجديد الخطاب

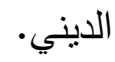
3- ضـرورة استخدام القائمين بالاتصـال في مجـال الخطـاب الديني والـدعوة مداخل إقناعية لإقناع المتلقين للرسالة الدينية.

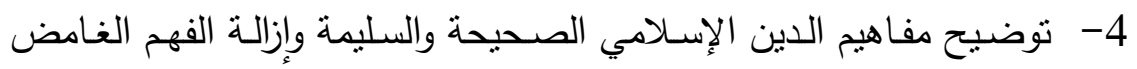
حول الإسلام والمسلمين. 
5- تحديد مواضع الضعف وأسبابه في الخطاب الديني الموجه للمسلمين.

\section{سابعًا: فروض الدراسة}

افترضت هذه الدراسة مجموعة من الفروض وسعت إلى التحقق من صحة هذه

$$
\text { الفروض أو عدم صحتها وهذه الفروض كالتالي: }
$$

1- الفـرض الأول: تجديد الخطـاب الـيني يـأتي استجابة لضـروريات دينيـة

وحياتية.

2- الفرض الثاني: توجد علاقة ارتباطية ذات دلالة إحصائية بين الأساليب

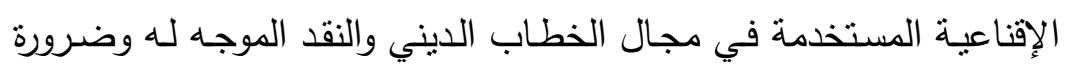
التجديد والاهتمام بالقائمين بالاتصال في مجال الفئل الدعوة.

3- الفـرض الثالـث: نوجد علاقة ارتباط ذات دلالـة إحصـائية بين الضـوابط

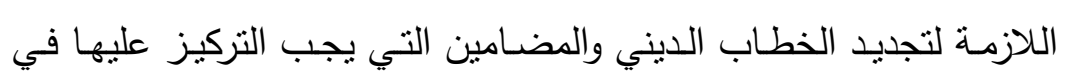

مرحلة ما بعد 25 يناير.

4- الفرض الرايع: نوجد فروق معنوية ذات دلالة إحصائية نظرًا لوجود اتجاهين

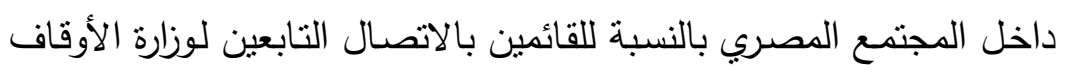

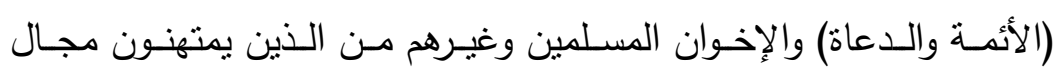

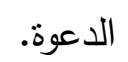

5- الفـرض الذــامس: نوجد علاقـة ارتبـاط ذات دلالــة إحصـائية بـين رؤى

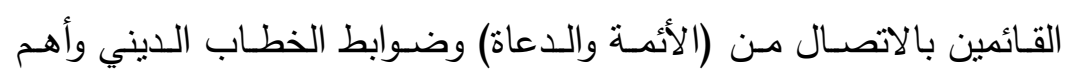
المضامين التي يجب التركيز عليها.

6- الفرض السادس: توجد علاقة ارتباط ذات دلالة إحصائية بين أهم القضايا

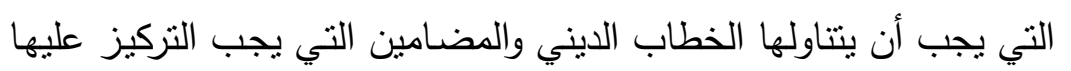
وأنسب الأفراد للاخول إلى مجال الخطاب الدعوة. 
هذه الدراسة تسعى إلى الإجابة على التساؤلات الآتية:

1- هل الخطاب الديني الحالي يتماشى مع فترة التحول السياسي في الدجتمع

$$
\text { المصري؟ }
$$

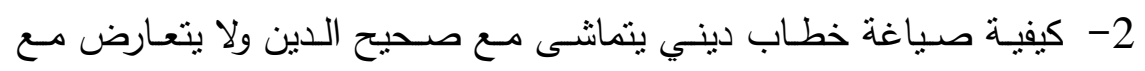

النصوص القرآنية والأحاديث النبوية أي القرآن والسنة.

3- هل لابد من إعمال العقل تجـاه الخطاب الديني الذي يُقال عبر منابر

$$
\text { المساجد؟ - الابد }
$$

4- ما هي أهم الوسائل لتجديد الخطاب الديني من وجهة نظر الأئمة والدعاة.

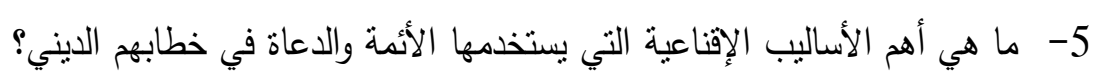

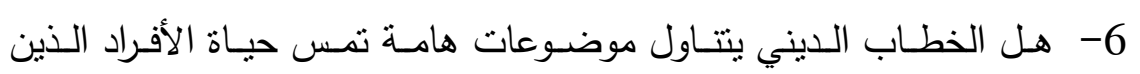

$$
\text { بستمعون إلى الخطاب الديني؟ }
$$

7- هل توجد اتجاهات أخرى تحساول تفنيد الخطاب الديني الذي تريده وزارة

$$
\text { الأوقاف؟ هل توجن }
$$

8- هل هناك اتجاه لتوحيد الخطاب الديني على مستوى الجمهورية كأسلوب

$$
\text { لتوحيد الصف؟ هل هاك }
$$

\section{تاسعًا: الإجراءات المنهجية للاراسة :}

\section{1 - نوع الاراسة والمنهج المستخدم :}

تتنمي هذه الدراسة إلى مصفوفة الدراسات الوصفية الني تستهذف نقرير ظاهرة

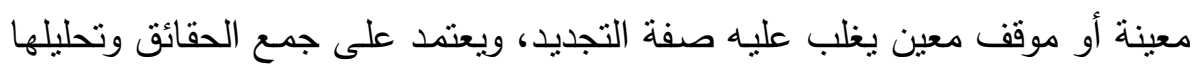

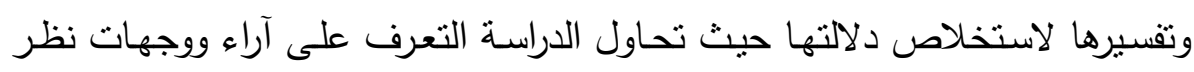

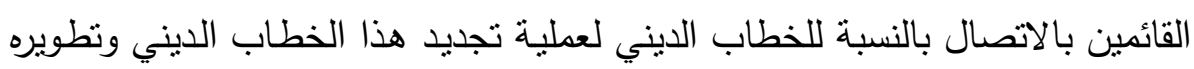

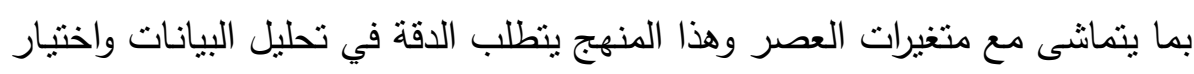

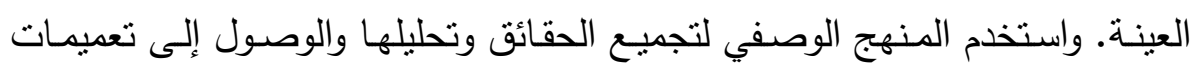




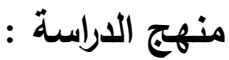

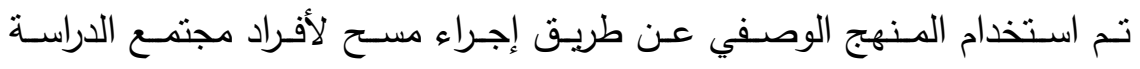

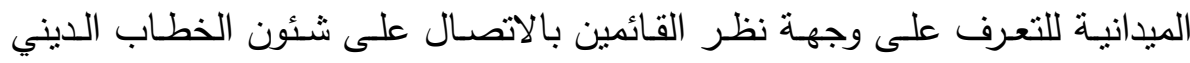
والدعوى حول كيفية صياغة خطاب ديني وكيفية تجديد هذا الخطاب بما يتمانشى مع الئح

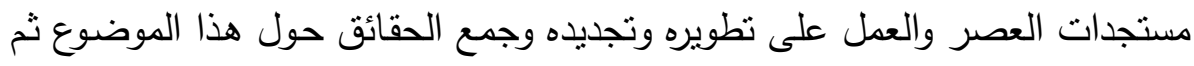

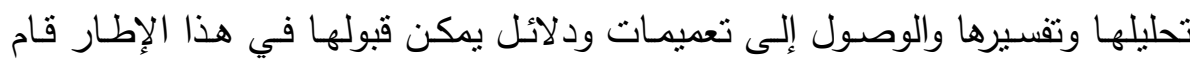
الباحث بتوظيف منهج المستح

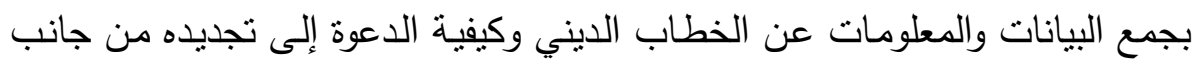
القائمين بالاتصال من الأئمة والوعاظ والدعاة.

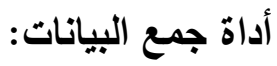

استخدم الباحث استمارة (الاستقصاء) في جمع البيانات من القائمين بالاتصـال والقائمين على الخطاب الديني حيث تعد استمارة "الاستقصاء" أحد الأساليب الأساسية الأسية

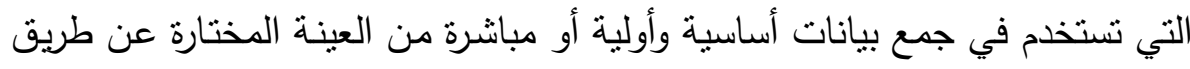

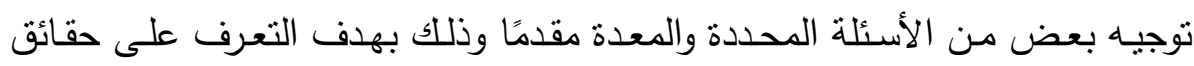

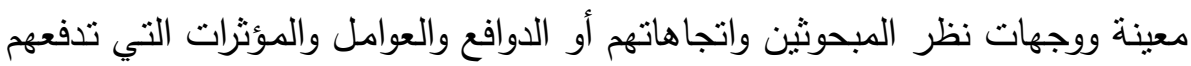
إلى تصرفات سلوكية معينة (40).

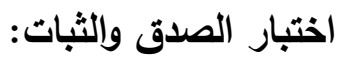

تم إعداد استمارة (الاستقصاء) الخاصة بجمع البيانات في ضوء المشكلة البحثية

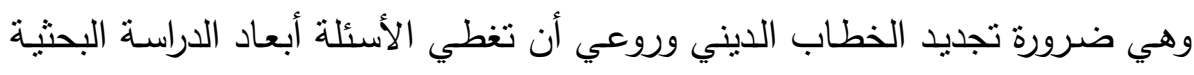

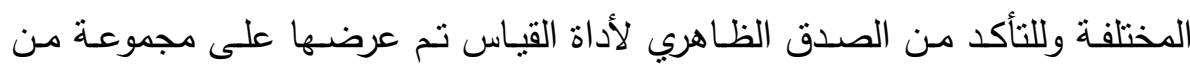

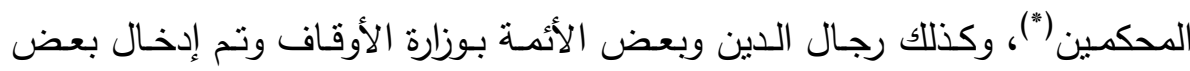

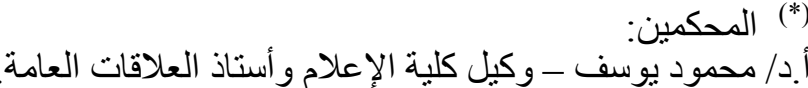

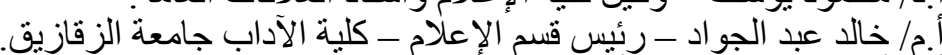

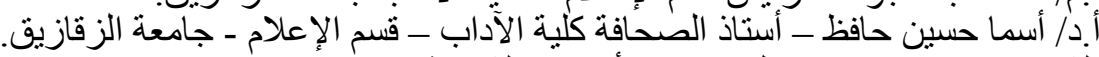

الثيخ مجدي بدر ان - وكيل وزارة الأوقاف بالثران الثرقية.

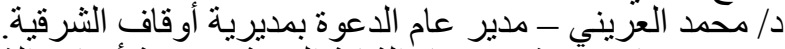
د د محمد حامد - مشرف النق عام الثقافة الدينية بمديرية أوقاف ألثرقية.

* أنظر ملحق (1). 
التعديلات على الاستمارة بناء على مقترحات المحكمون من أساتذة الإعلام وكذلك

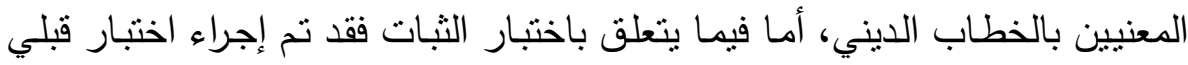
للاستمارة (Pretest) تم تطبيقه على 20 مفردة من المبحوثين تم اختيارهم عشوائياً

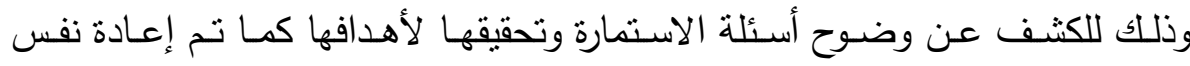

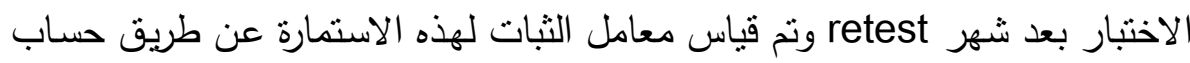

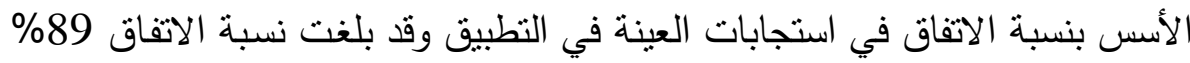
وهي نسبة مرتفعة تجعل أداة القياس صالحة للنطبيق.

وبعد التأكد من صدق الاستمارة وثباتها قام الباحث بتطبيق الاستمارة على عدد

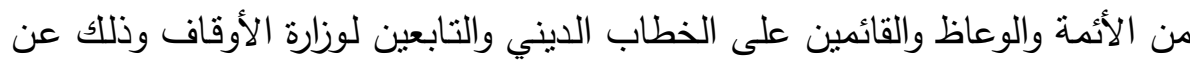

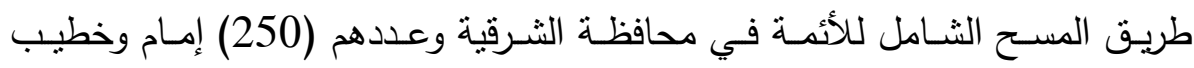
تابعين لمديرية الأوقاف بمحافظة الثرقية.

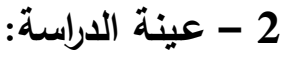

اختار الباحث عينة قوامها (250) إمام وخطيب معينين من قبل وزارة الأوقاف إناف يحملون مؤهلات أزهرية ويمارسون عملهم لأنهم هم المسئولون عن الخطاب الديني

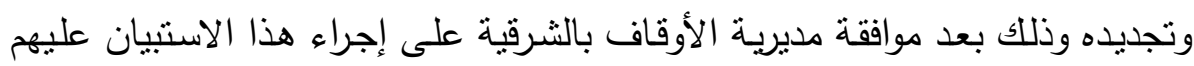

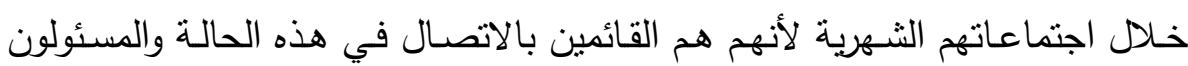

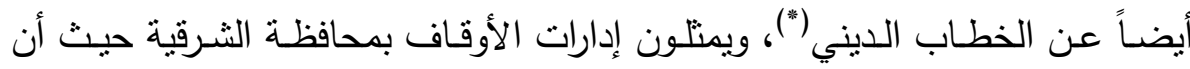
الثرقية بها (31) إدارة وتم اختيار محافظة الثرقية لانتماء الباحث لها.

\section{Purposive العينة المقصودة}

تم الاستعانة بالعينة المقصودة وتعني أن يتعدد الباحث أو يقصد إجراء الدراسة

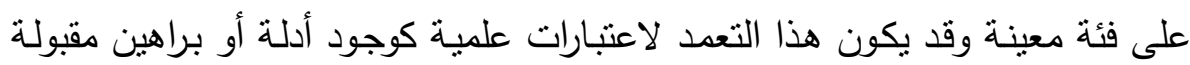

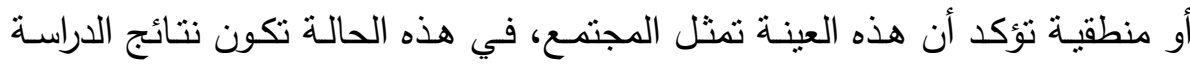
مقبولة، وقد تكون العينة الدقصودة مبررة لاعتبارات واقعية أو منطقية (41). ولذلك كانت عينة الدراسة موضع البحث من الأئمة والدعاة الذين يتبعون وزارة

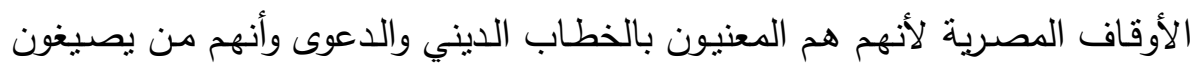


الخطاب الديني للجماهير من المسلمين الذين يحضرون خطبة الجمعة ويستمعون إلى هؤلاء الخطباء والدعاة في اللقاءات والندوات والهناسبات والاحتفالات الدينية.

أهم خصائص أفراد عينة الاراسة:

جدول (1) يوضج أهم خصائص عينة الداسة

\begin{tabular}{|c|c|c|c|c|c|}
\hline$\%$ & ك & المؤهل & $\%$ & ك & \% \\
\hline 75.6 & 186 & ليسانس أصول دين ودعوة & 10.2 & 25 & من 20 إلى أقل من 30 \\
\hline 14.6 & 36 & ليسانس شريعة وقانون & 26.5 & 65 & 30 إلى أقل من 40 \\
\hline 3.6 & 9 & ماجنتير & 36.5 & 90 & 40 \\
\hline 6.2 & 15 & ل دكتوراه & 26.8 & 66 & 50 إلى أقل من 60 \\
\hline 600 & 246 & | الإجمالم & $\% 100$ & 246 & \\
\hline
\end{tabular}

تشير بيانات الجدول السابق إلى أن فئة السن من 40 إلى أقل من 50 بلغت

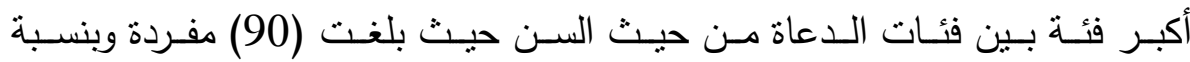
(656.5\%)، بينما جاءت فئة من 30 (إلى أقل من 40 سنة فئة في المرتبة الثانية حيث

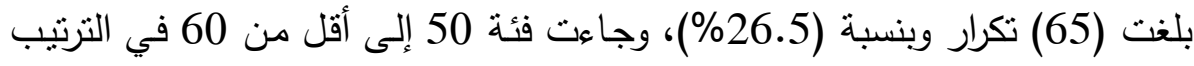

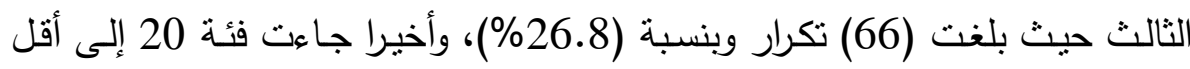

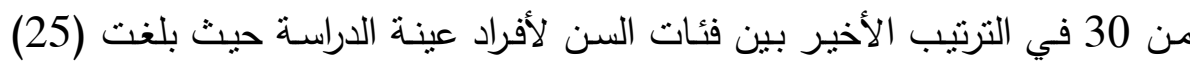

$$
\text { تكرار وبنسبة (10.2\%). }
$$

أما بالنسبة للمؤهل الدراسي فتعددت مؤهلات الذين يعملون في مجال الدعوة

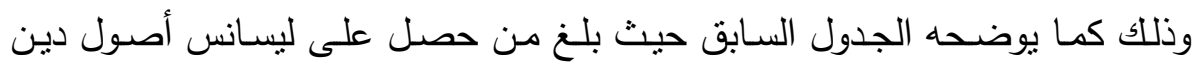

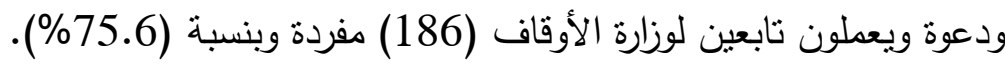

فيما جاء في الترتيب الثالث ليسانس شريعة وقانون بعدد قدره (36) وبنسبة

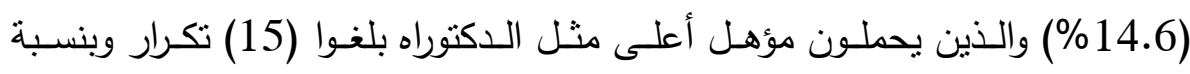

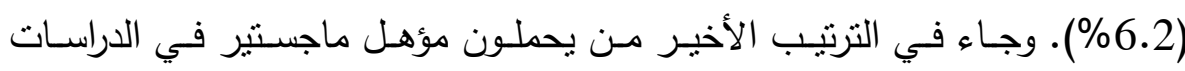
الإسلامية بعدد قدره (9) وبنسبة (3.6\%). 
ومن الملاحظ أن الذين يعملون في مجال الدعوة وتابعين لوزارة الأوقاف يحملون مؤهلات أزهرية سواء ليسانس أصول دين قسم تفسير وقسم عقيدة وفلسفة إسلامية،

أو ليسانس الدراسات الإسلامية، أو كلية اللغة العربية جامعة الأزهر .

كما أن هناك من يحملون درجة الدكتوراه في مقارنة الأديان والدذاهب أو دكتوراه

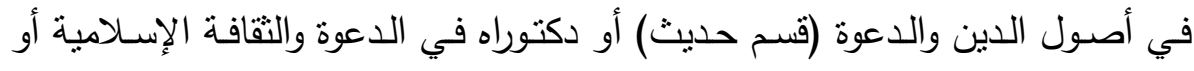

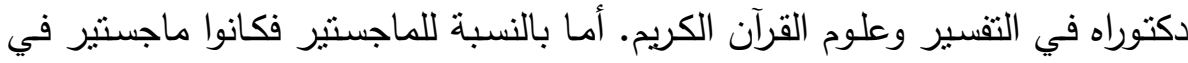
أصول الدين والدعوة الإسلامية أو الثقافة الإنسلامية.

\section{الوسائل الإحصائية التي استخدمها الباحث:}

استخدم الباحث عدد من الوسائل الإحصائية مثل:

$$
\text { - معامل الارتباط والنوافق معامل "بيرسون". }
$$

- بعض المقاييس الإحصائية الوصفية البسيطة الوسط الحسابي - الانحراف

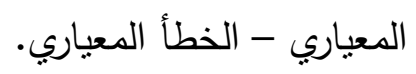

- اختبار T-test لدراسة الفروق المعنوية بين مجموعتين مستقلتين.

- - استخدام بعض العطليات الإحصائية مثل كا².

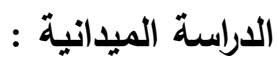

\begin{tabular}{|c|c|c|c|c|c|}
\hline الدلادة & | اللالة & قيمة كا2 & $\%$ & ك & احتياج الخطاب الايني إلى المبليد \\
\hline لدالة & - & 101.48 & 82.4 & 202 & نعم \\
\hline- & - & 101.48 & 17.6 & 44 & إلى حد ما \\
\hline- & - & - & - & - & 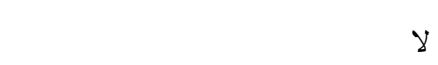 \\
\hline | دالة & | صفر & 101.48 & $\% 100$ & 246 & بمالد \\
\hline
\end{tabular}

جدول (2) يوضح احتياج الخطاب الايني إلى التجديد والتطوير

تشتير بيانات الجدول السـابق (2) أن هنـاك احتباج شديد إلى تجديد الخطاب

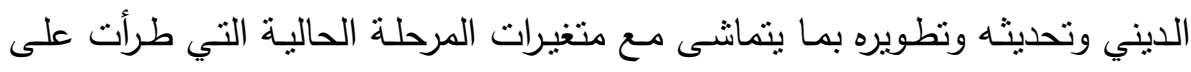

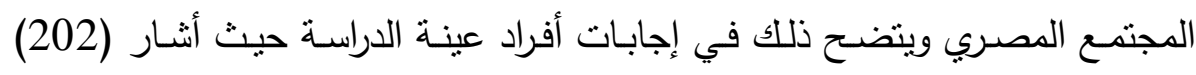


مفردة بنسبة (82.4\%) بأن الخطاب الديني يحتاج إلى تجديد بينما أنشار (44)

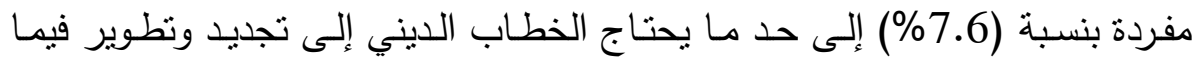
اختقت فئة (لا) ولم تظهر بين الفئات.

إذن هناك احتياج شديد لتطوير الخطاب الديني داخل المجتمع المصري وعلى الدئ

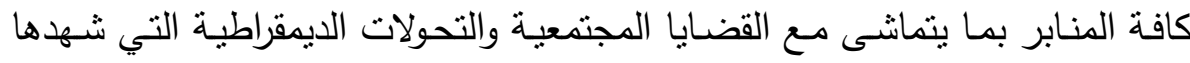
المجتمع المصري. ومما يدل على ذلك ما تتاولته ونشرته جريدة الأهرام تحت عنوان (إلى أي مدى نحتاج لتجديد الخطاب الديني)(42). إن ما يثار حول تجديد الخطاب الديني هو حق أريد به باطل، أما أنه حق، فلأن

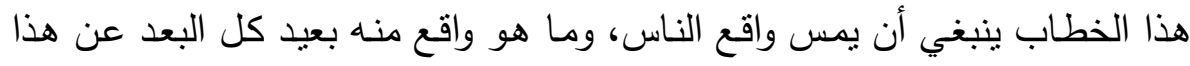

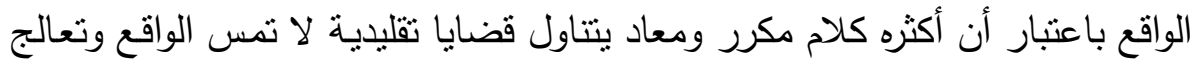

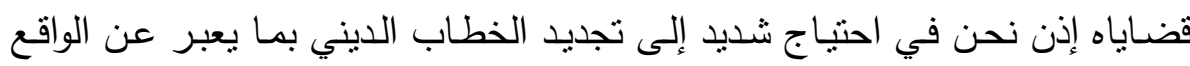

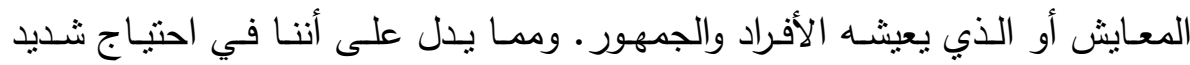

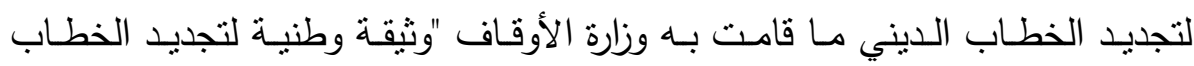

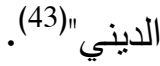

قررت وزارة الأوقاف عقد مؤتمر وطني موسع بمشاركة علماء الدين ودعاة وأئمسة

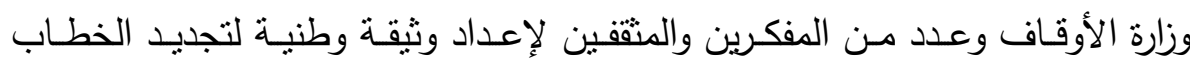

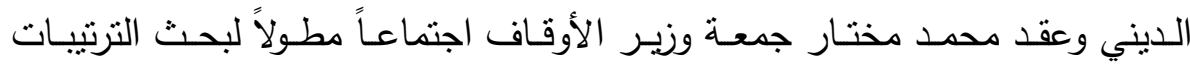

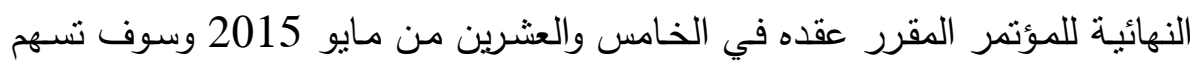
رؤى ومقترحات حادة في ردم الفجوة بين الواقع والمأمول في الخطاب الديني من مائ جدول (3) الجهات المعنية بتطوير وتجديد الخطاب الديني

\begin{tabular}{|c|c|c|c|c|c|}
\hline الالالة & مسلالوي & قيمة كا2 & $\%$ & ك & الجهـات المغيـة بتطــوير الخطـاب \% \\
\hline & & & 5 & 117 & إلثريف \\
\hline غير دالة & 0.444 & 0.585 & 52.4 & 129 & الأوقافت \\
\hline & - & - & - & - & إكز الإسلادية بالخارج \\
\hline- & - & - & - & - & فارات والقتصليات \\
\hline غنر | غ | & 444 & 85 & 00 & 46 & \\
\hline
\end{tabular}




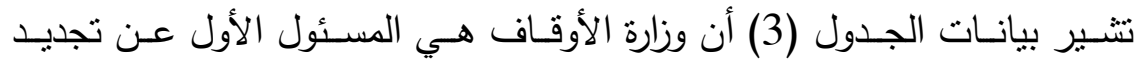

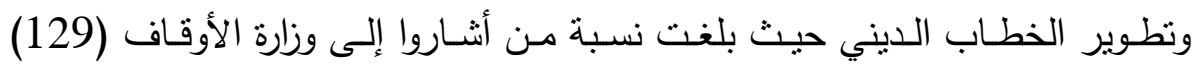
وبنسبة (52.4\%) بينما جاء الأزهر الثريف في المرتبة الثنانية وبتكرار قدره (117) وبنسبة (47.6\%). ويوضـح ذلك أن وزارة الأوقـاف هـي المعنيـة بالدرجـة الأولى بتجديــ ونطـوير

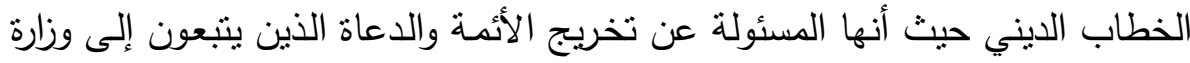

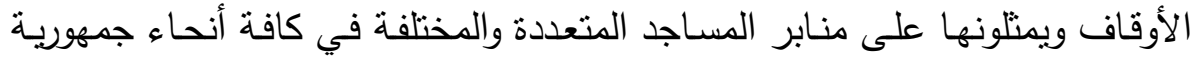

$$
\text { مصر العربية. }
$$

ثم كان هناك دور مماثل إلى الأزهر الثريف وذلك لأنه هو السئول عن كافة

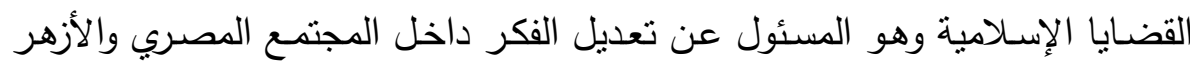
الثريف هو منارة الإسلام والمسلعين في الداخل والخارج.

ويتضح ذلك في ما تناولته جريدة الأهرام تحت عنوان "بدء الخطوات التنفيذية

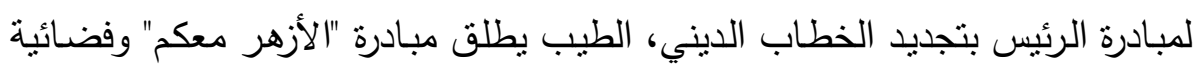

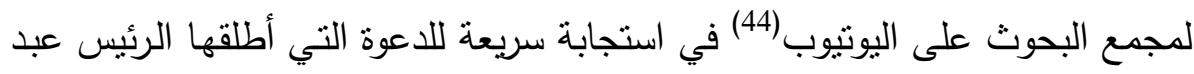

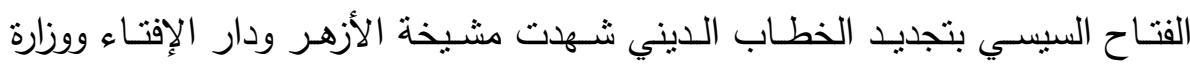

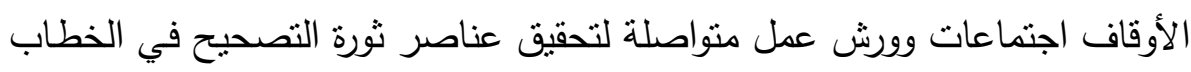

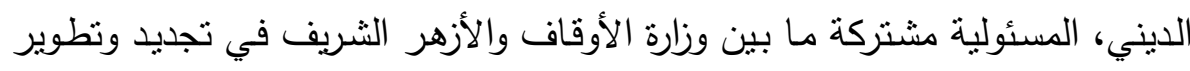
الخطاب الديني لحماية المجتمع المصري.

جدول (4) التجديد في الخطاب الايني داخلياً وخارجياً

\begin{tabular}{|c|c|c|c|c|c|}
\hline الدلالة & مستوى الدلالة & قيمة كا2 & $\%$ & ك & التجدليد في الخطاب الايني داخلياًُ وخرجياً: \\
\hline- & - & 225.46 & 78 & 192 & في الداخل \\
\hline دالة & - & 225.46 & 5.7 & 14 & في الخارج \\
\hline- & - & 225.46 & 16.3 & 40 & داخلياً وخارجياً \\
\hline دالة & صفر & 225.46 & $\% 100$ & 246 & الإجمالي \\
\hline
\end{tabular}

تنشير بيانات الجدول (4) إلى أننا نحتاج إلى تجديد الخطاب الديني في الداخل والخارج وفي الداخل والخارج سوياً. 
وتثتير الأرقـام أن (192) تكرار وبنسبة (78\%) أثــاروا إلى تجديد الخطـاب

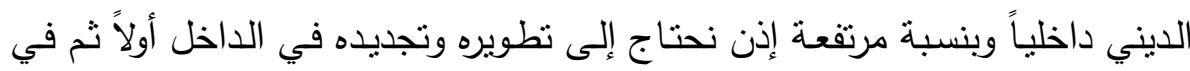

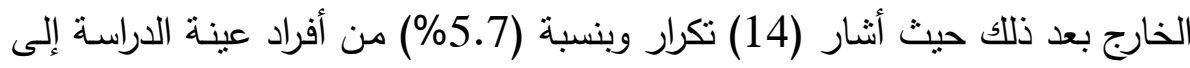
أننا نحتاج أيضاً إلى تطوير الخطاب الديني في الخارج. بينما أثنار عدد (40) تكرار بنسبة (16.3\%) إلى أننا نحتاج إلى التطوير في

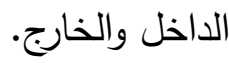
الاحتباج الأكثر في تجديد الخطاب الديني في الداخل أولاً ثم في الخارج بعد ذلك

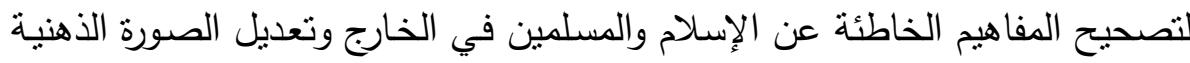
التي اتخذها الغرب عن المسلمين والإسلام وإبراز الحقيقة لهم. ومما يدل على ذلك "الإرهاب شوه صورة المسلمين في العالم، ولابد من ثورة

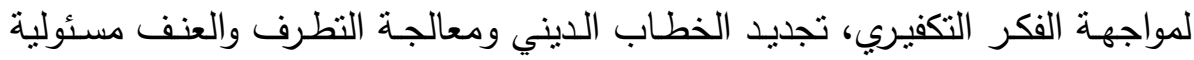
الأزهز والدعاة أمام الهة"(45).

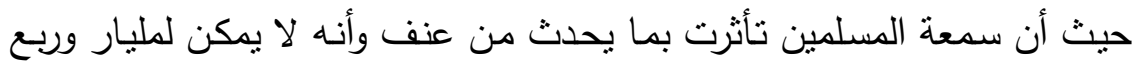

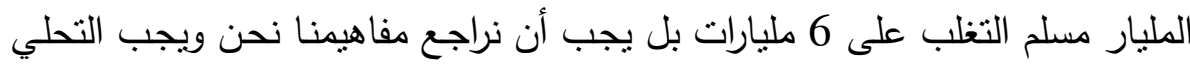

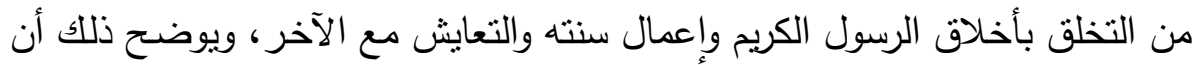

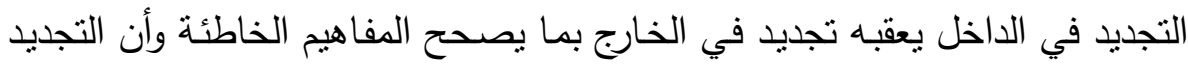

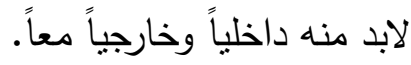
جدول (5) الخطاب الايني الحالي يتماشى مع فترة التحول العياسي في المجتمع المصري

\begin{tabular}{|c|c|c|c|c|c|}
\hline الدلالة & مسلالة & قيمة كا2 & $\%$ & s & مسايرة الخطاب الليني للتحول السياسي، $\%$ \\
\hline- & - & 90.829 & 8.1 & 20 & يتماشى مع فترة التحول السياسي \\
\hline دالة & - & 90.829 & 3.41 & 84 & 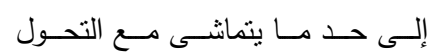 \\
\hline- & - & 90.829 & 57.7 & 143 & لا بتماشى مع التحول السباسى \\
\hline دالة & صفر & 90.829 & $\% 100$ & 246 & جما \\
\hline
\end{tabular}

يتضح من الجدول (6) أن أغلب أفراد الدراسة وبعدد قدره (142) تكرار وبنسبة

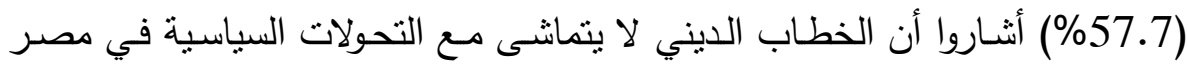
بينما أنثار عدد قدره (84.7) وبنسبة (34.1\%) أنه إلى حد ما يتمانشى مـع التحولات 
السياسية، وأخيراً جـاءت فئة يتماثسى مـع التحول السياسي بعدد قدره (20) تكرار

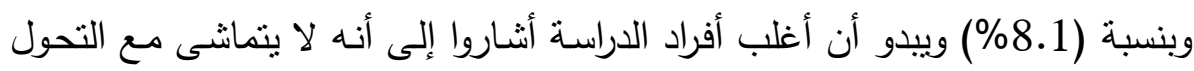

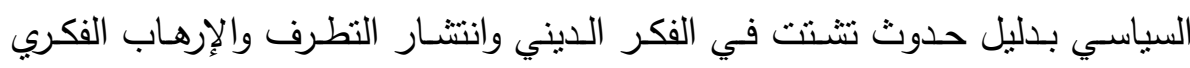

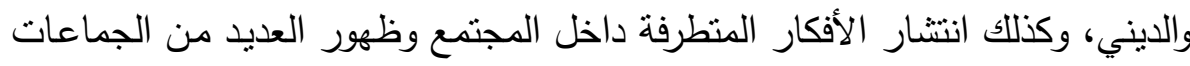
الدينية التي تهدد سماحة الدين الإسلامي.

وكذلك بروز تناقضـات بين غالب الخطابـات والمنظومـات الفكريـة الإسـلامية

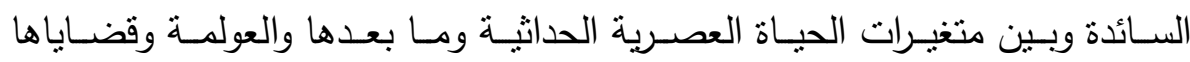
وتنقنهاتها.

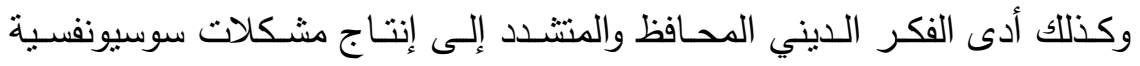

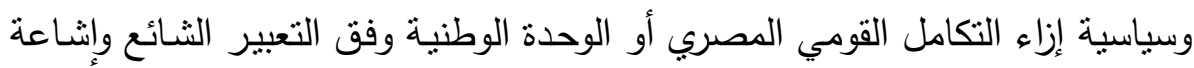

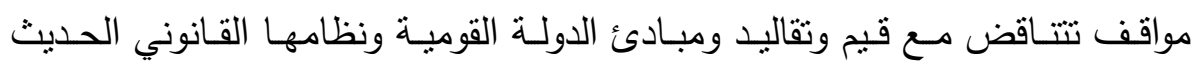
وحريات التدين والاعتقاد.

ويتضح من ذلك أن الخطاب الديني لا يتمانشى مع التحول السياسي الذي شهره

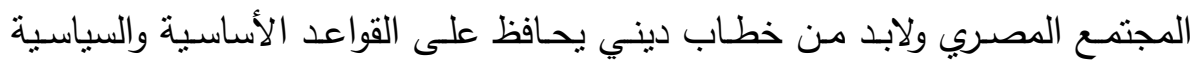

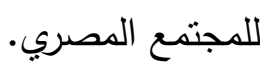
جدول (6) الضوابط اللازمة لتجديد وتطوير الخطاب الديني

\begin{tabular}{|c|c|c|c|c|c|}
\hline الالالة & م الدلالة & قيمة كا2 & $\%$ & ك5 & \% ك \\
\hline- & - & 57.612 & 38.4 & 95 & أن يسنقى الخطاب الديني من القرآن والسنة \\
\hline- & - & 57.612 & 24 & 50 & لا يتعارض مع صحيح الإنسلاح \\
\hline دالة & - & 57.612 & 11.5 & 28 & ووسطينه أن يركز على بســاطة وســاحة الإنــلام \\
\hline- & - & 57.612 & 14.6 & 36 & لا يأتي بأثنياء غير موجودة في الإسلام \\
\hline- & - & 57.612 & 11.5 & 28 & ألاين يسـاعد على نثـر الفكر الدنطـرف فـي \\
\hline- & - & - & - & - & أن يكون الخطاب بالضبط توازن المجتمع \\
\hline- & - & - & - & - & أخرى تذكر \\
\hline دالة & صفر & 57.612 & $\% 100$ & 246 & 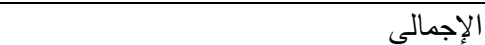 \\
\hline
\end{tabular}

يشير الجدول (7) إلى أن هناك مجموعة من الضوابط اتفق عليها أغلب أفراد

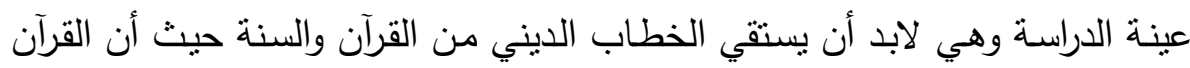

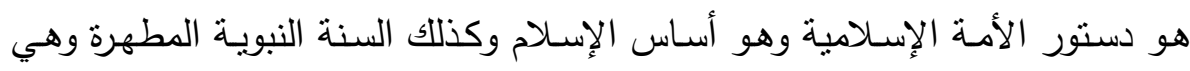


المكملة للدين الإسلامي وذللك بتكرار قدره (95) وبنسبة (38.4\%) ويدل ذلك على آلى أن القرآن الكريم هو أساس كل تجديد حيث فيه كل ما يهم أمور الإسلام والمسلمين.

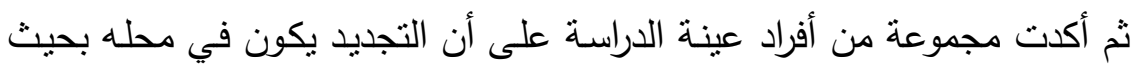

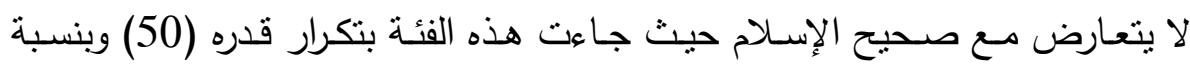

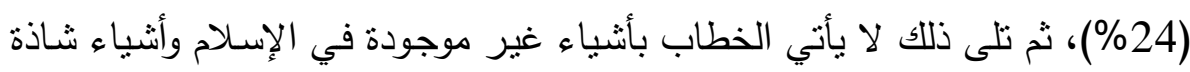

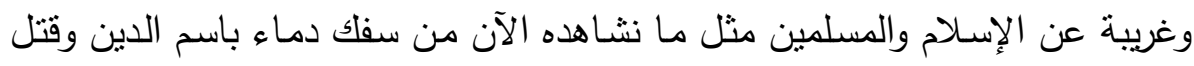

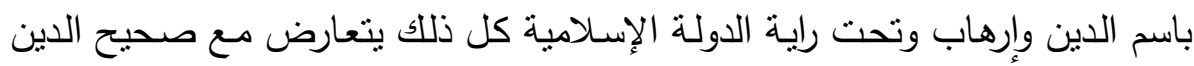
لأن الدين الإسلامي ليس دين قتل وإرهاب.

وجاءت فئة أن يركز الخطاب الديني على سماحة وبساطة الإسـام ووسطيته وتساوت مـع ألا يساعد على نشر الفكر المنطرف حيث جاءت كلابه سلها بتكرار قدره

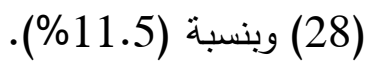

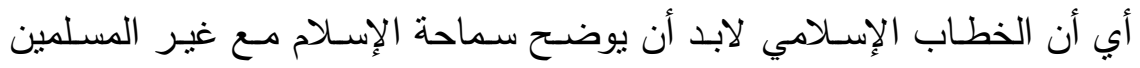

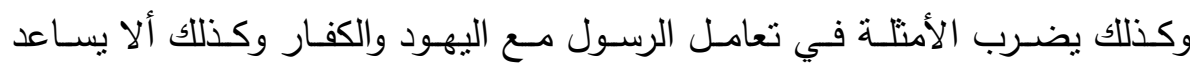

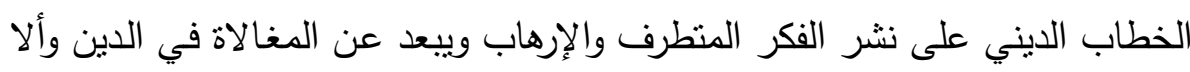
يكون الدين الإسلامي هو الداعي للنطرف الديني والفكري. ويتضح ذلك في ما تتاولته جريدة الأهرام تحت عنوان "الصحفيون في لقاء ساخن

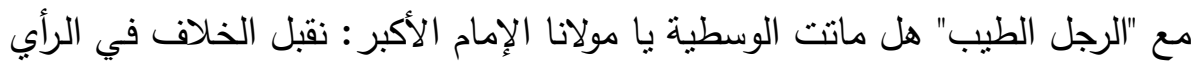

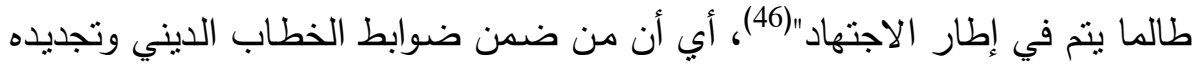
لابد من التركيز على وسطية الإسلام.

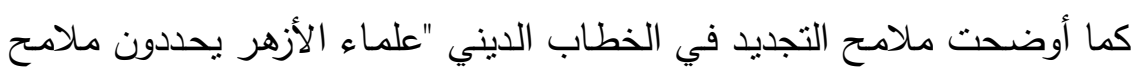
تجديد الخطـاب الديني، البعد عن الآراء الثـاذة وتتـاول القضــايا المعاصـرة ونشـر

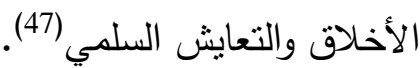

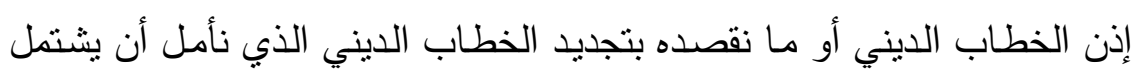

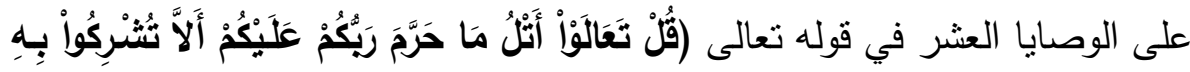

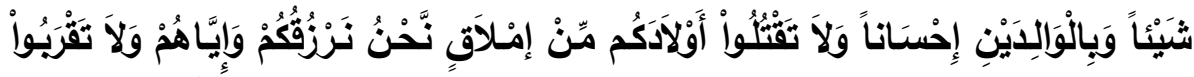

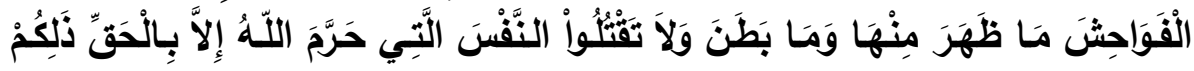




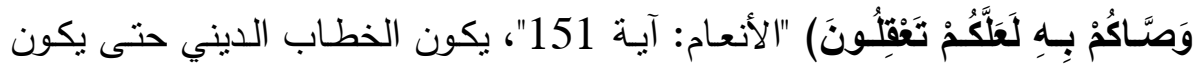

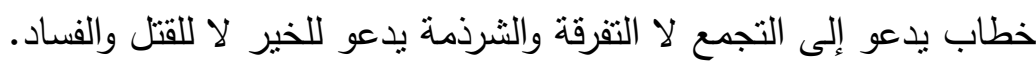

جدول (7) القضايا التي يجب أن يتناولها الخطاب الايني ويركز عليها

\begin{tabular}{|c|c|c|c|c|c|}
\hline الدلالة & 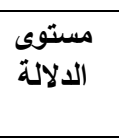 & قيمة كا2 & $\%$ & ك & القطابيا التي يجب أن يركزي عليها \\
\hline- & - & 235.463 & 30.9 & 76 & العدل والمساواة بين جميع الأفراد \\
\hline- & - & 235.463 & 20 & 54 & نشر الفكر الديمقراطي السليم \\
\hline- & - & 235.463 & 2.4 & 6 & التأكيد على مبدأ التكافل داخل المجتمع \\
\hline دالة & - & 235.463 & 6.5 & 16 & احترام وقبول الآخر \\
\hline- & - & 235.463 & 9.8 & 24 & الالتزام بالتعاون مع الدول \\
\hline- & - & 235.463 & 4.1 & 10 & سماحة الدين الإسلامى \\
\hline- & - & 235.463 & 24 & 60 & والتطرفيح دور الإســام في محاربـة الإرهـاب \\
\hline- & - & - & - & 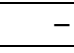 & أخرى تذكر \\
\hline دالة & صفر & 235.463 & $\% 100$ & 246 & 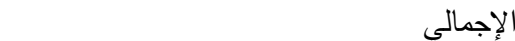 \\
\hline
\end{tabular}

يتضح من الجدول (8) أن أهم القضايا التي يحتاجها الخطاب الديني للمناقثـة

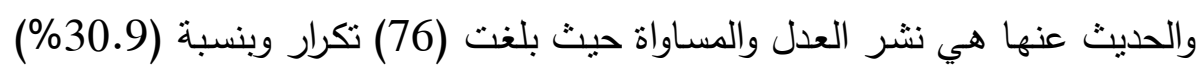

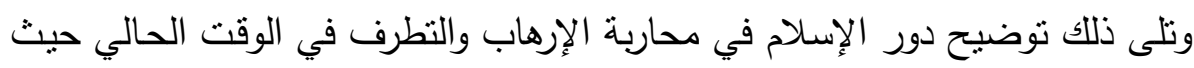

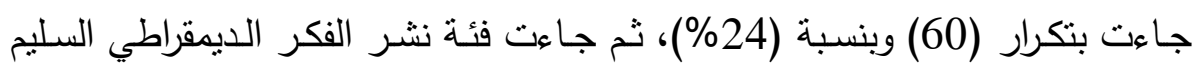

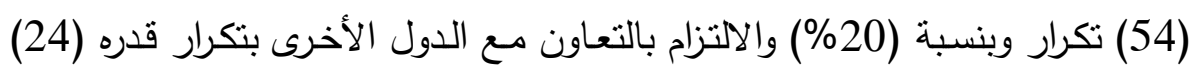

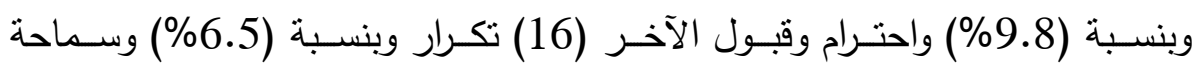

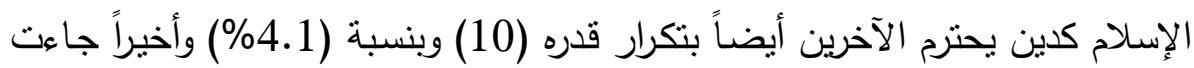

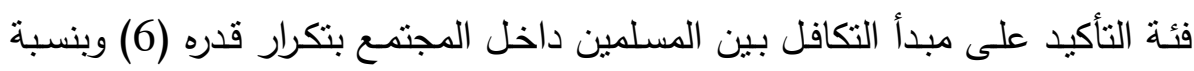
.$(\% 2.4)$

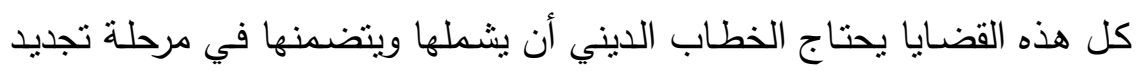

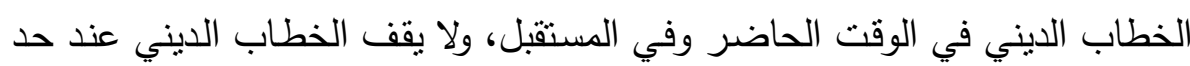

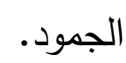

التجديد التي نذهب إليه هنا هو ذلك التجديد الذب جاء انطلاقاً من حديث النبي

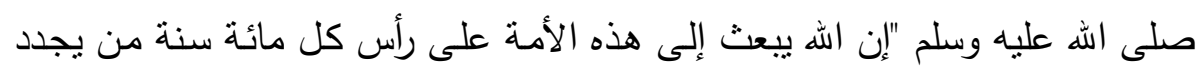

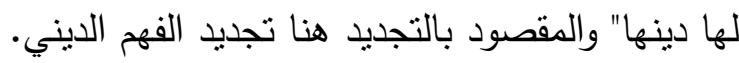


والتجديد هنا في القضايا والموضوعات التي يحتاجها الخطاب الديني وهو عملية

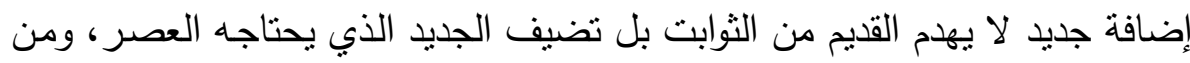

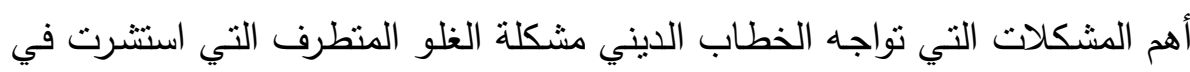

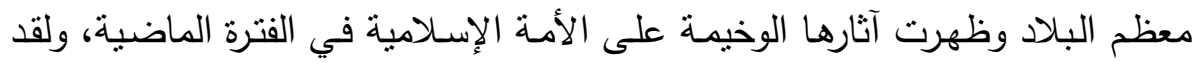

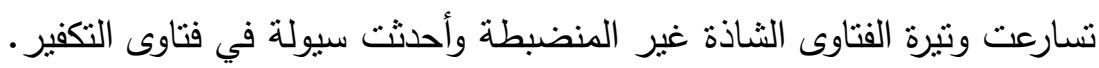
لذلك يجب أن ينشر الخطاب الديني مبادئ العدل والمساواة بين جميع أفراد

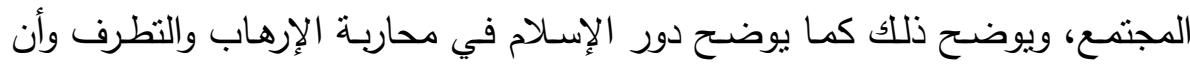

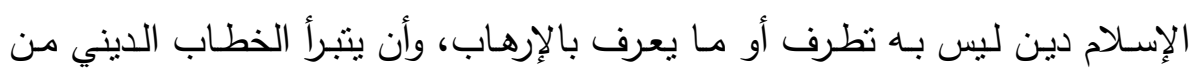

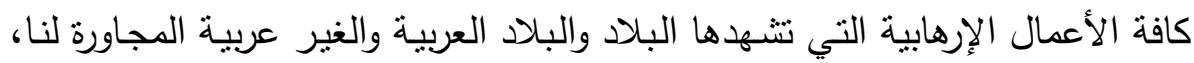

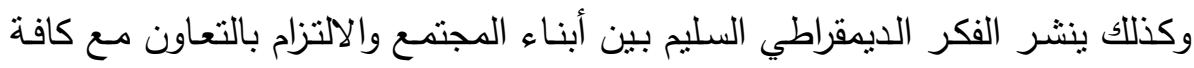

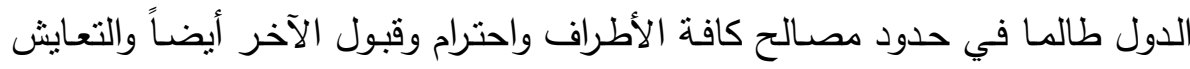

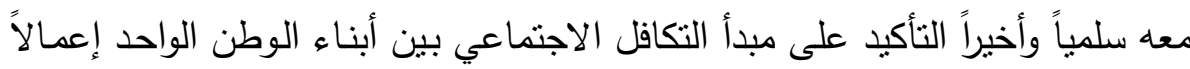

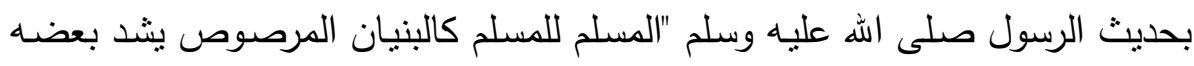

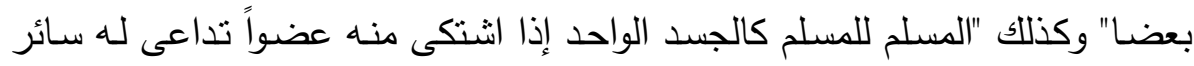

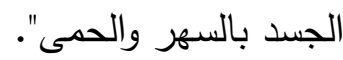

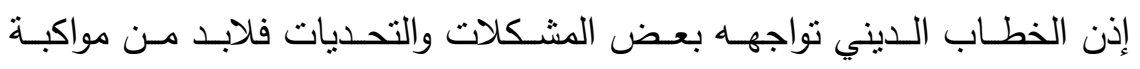

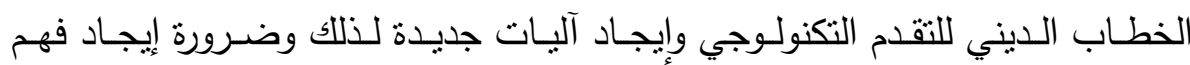

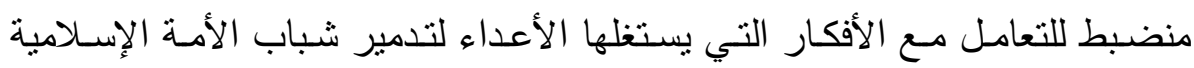
وزعزعة قيمهم ومبادئهم. 
جدول (8) المضامين التي يجب التركيز عليها في الخطاب الايني

\begin{tabular}{|c|c|c|c|c|c|}
\hline الدلالة & مستوي & قيمة كام2 & $\%$ & ك & المضامين التي يجب التركيز عليها ك، \% \\
\hline- & - & 285.789 & 7.4 & 18 & المضامين المتعلقة بالمعاملة مع الغير \\
\hline- & - & 285.789 & 15.8 & 39 & الإسلامية مين التــي تــدعو إلـى نثـــر القـيم \\
\hline- & - & 285.789 & 2.5 & 6 & المضامين التى تدعوك إلى عمل الخير \\
\hline دالة & - & 285.789 & 30 & 74 & الدضامين التي تدعو إلى تماسك المتتمع \\
\hline- & - & 285.789 & 8.3 & 20 & والعدل المضامين التـي تـدعو إلـى نشـر المســاواة \\
\hline- & - & 285.789 & 14 & 35 & والمجتمعـعين التــــــــو إلـى حـب الــوطن \\
\hline- & - & 285.789 & 12.3 & 30 & والدول النـامين التـي تـدعو إلـى وحـدة المجتهـع \\
\hline- & - & 285.789 & 8.9 & 22 & 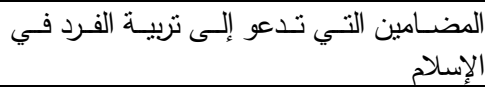 \\
\hline- & - & 285.789 & 0.8 & 2 & المضامين التي تدعو إلى نبذ العنف والتقرقة \\
\hline- & - & - & - & - & أخرى تذكر \\
\hline دالة & صفر & 285.789 & $\% 100$ & 246 & 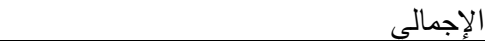 \\
\hline
\end{tabular}

يتضح من الجدول (9) أن المضامين التي يجب أن يركز عليها الخطاب الديني

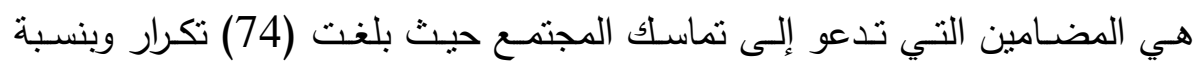
(30\%)، ثم جاءت المضامين التي تدعو إلى نشر القيم الإسـامية بتكرار قدره (39) وبنسبة (15.8\%) والمضـامين التي تدعو إلى حب الوطن والمجتمـع بتكرار قدره

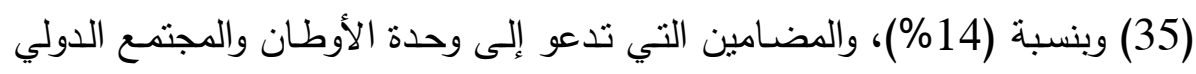

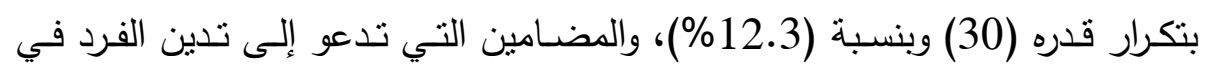
الإسـام (22) تكرار وبنسبة (8.9\%)، ومضامين نشر العدل والمساواة (20) (تكرار

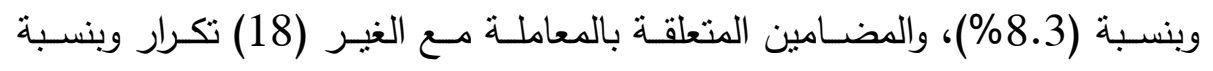

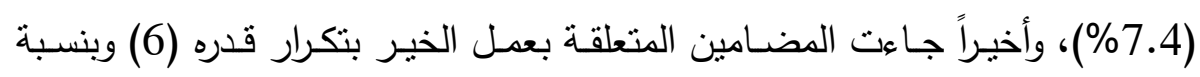
(2.5\%) والمضامين المتعلقة بنبذ العنف والتفرقة (2) تكرار وبنسبة (0.8\%).

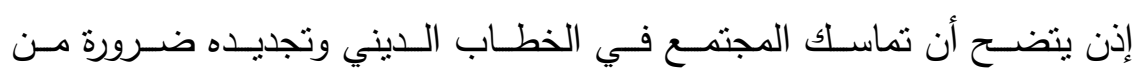

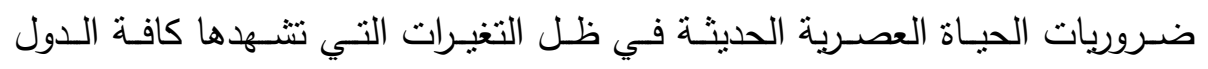
والأقطار العربية على وجه الخصوص. وأن الخطاب الديني وتجديده يجب أن ينتـاول القضـايا المعاصرة وبيـان الأحكام الثرعية في هذه القضـايا بالتركيز على مكارم الأخـاق والبعد عن التشرذم والتأكيد 
على توافق المصلحة (مصلحة الوطن) مع الدين فأينما نكون الدصلحة تنت شرع الها

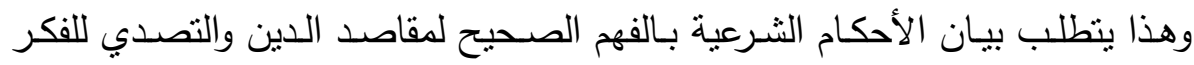

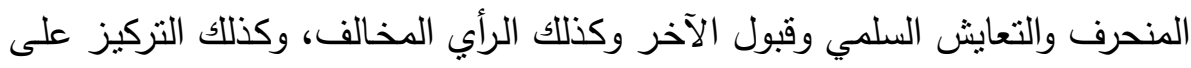

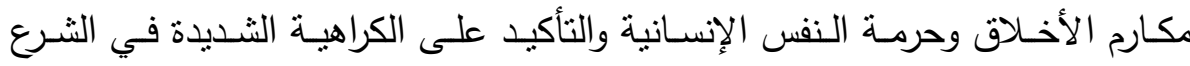

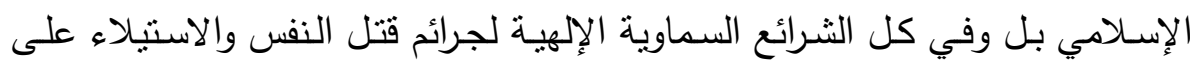

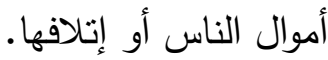

ويركز أيضاً على نشر الآراء والقيم التي تدعو إلى نثر القيم الإسلامية والتماسك بين

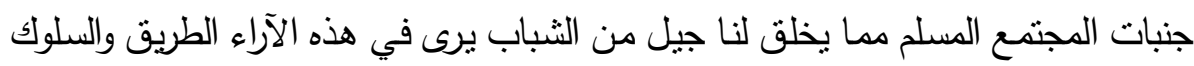
السليم.

جدول (9) أنسب الأفراد للاخول إلى مجال الدعوة

\begin{tabular}{|c|c|c|c|c|c|}
\hline الدلالة & مستلوي & قيمة كا2 & $\%$ & ك & أنسب الأفراد للاعوة \\
\hline- & - & 35.919 & 30.9 & 76 & داعية متخصص \\
\hline دالة & - & 35.919 & 69.1 & 170 & علماء الأزهر \\
\hline- & - & - & - & - & بعض الأفراد يرغبون في الدعوة علماء الدين \\
\hline- & - & - & - & - & كل ما سبق \\
\hline دالة & صفر & 35.919 & $\% 100$ & 246 & 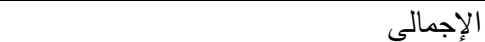 \\
\hline
\end{tabular}

تثير بيانات الجدول (10) أن علماء الأزهر هم أنسب الأفراد لـخول مجال

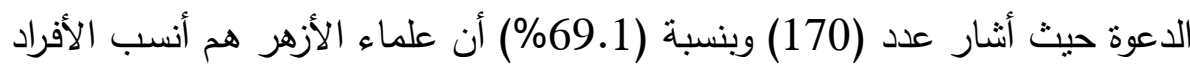

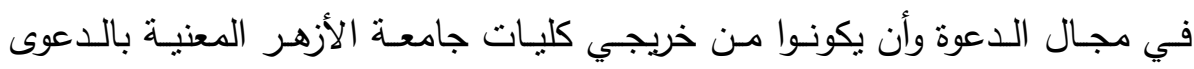
والعقيدة والفلسفة الإسلامية وما إلى ذلك.

ثم جاءت فئة داعية متخصص بعدد قدره (76) نكرار وبنسبة (30.9\%) وهؤلاء دعاة متخصصون في مجال الدعوة وخريجي معاهد الدعاة الإسـلامية وهم أهل ألهل تخصص في مجال الدعوة ويحملون مؤهلات أزهرية أيضاً.

وذلك لأن الداعية على الحقيقة يحمل على عاتقه مهمة خطيرة وشديدة الأهمية

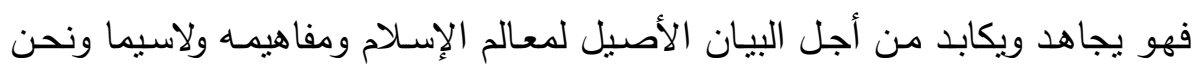

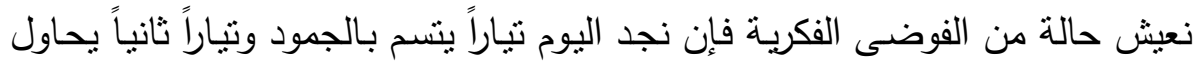

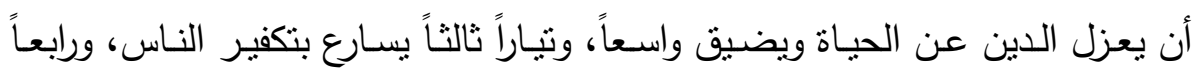

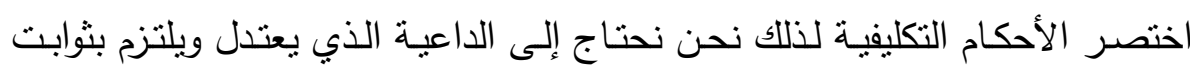


الدين مع مراعاة مقتضيات العصر ويتسم بالمرونـة ويراعي مصلحة الزمان والمكان ويقوم على إحياء تعاليم الإسـام بخطاب مستتير في رحاب النصوص ويعدل على ولى ويلى

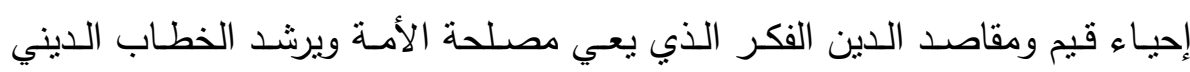

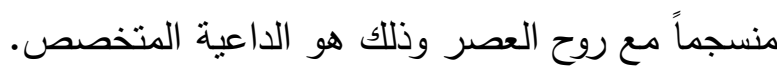
جدول (10) أهم الأساليب الإقتاعية المستخدمة في مجال الخطاب الديني والاعوة

\begin{tabular}{|c|c|c|c|c|c|}
\hline الدلالة & مالدلةوى & قيمة كا² & $\%$ & S & الأساليب الإقتاعية \\
\hline- & - & 449.390 & 48.7 & 120 & أسلوب الدعوة والموعظة الحسنة \\
\hline- & - & 449.390 & 27.6 & 68 & أسلوب التزغيب والتزهيب \\
\hline دالة & - & 449.390 & 3.7 & 9 & أسلوب الترغيب في الدين الإسلامي \\
\hline- & - & 449.390 & 1.3 & 3 & أسلوب السرد القصصى \\
\hline- & - & 449.390 & 10 & 22 & أسلوب مخاطبة العقل والهنطق \\
\hline- & - & 449.390 & 5.7 & 14 & أسلوب القدوة الحسنة \\
\hline- & - & 449.390 & 4 & 10 & أخرى تذكر \\
\hline دالة & صفر & 449.390 & $\% 100$ & 246 & 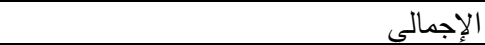 \\
\hline
\end{tabular}

يوضـح الجدول (11) أهم الأسـاليب والمداخل الإقناعيـة المستخدمة في مجـال الخطاب الديني ومحاولة تجديد الخطاب الديني حيث جاء أسلوب الدعوة والموعظة الدهة الحسنة في المرتبة الأولى بتكرار قدره (120) وبنسبة (48.7\%)، بينما جاء أسلوب الترغيب والترهيب بتكـرار قدره (68) وبنسـبة (27.6\%)، وأسـلوب مخاطبـة العقل بالمنطق بتكرار قدره (22) وبنسبة (10\%)، وأسلوب القدوة الحسنة بتكرار قدره (14)

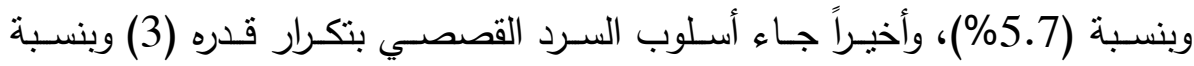

يتضـح من ذلك أن أفضل الأسـاليب الإقناعيـة في ملامسح التجديد في الخطاب الديني هو أسلوب الدعوة والموعظة الحسنة إعمالاً لقول الحق سبحانه وتعالى (أدعو لإنو

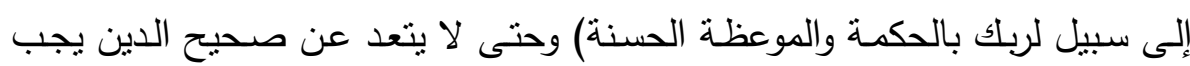
إتباع هذا الأسلوب في مجال الدعوة وفي الخطاب الديني. وأيضاً إتباع أسلوب الترغيب والترهيب وهو إبراز الأجر العظيم في حالة الإتباع الجيد لتعاليم الدين الإسـاهي والعقاب في حالة مخالفة تعاليم الدين الإسـامي إعمالاً لقول الحق (ومن يعرض عن ذكري فإن لله معيثـة ضنكا ونحشره يوم القيامـة أعمى الإيى

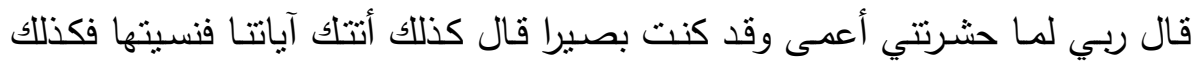
اليوم تتسى) صدق الله العظيم. 


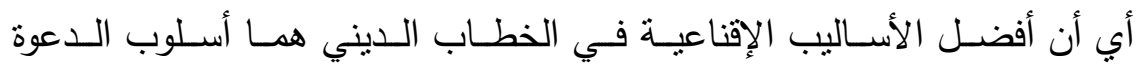

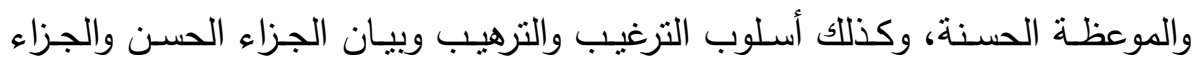
العقابي للمخالفين للنصوص الإسلامية. جدول (11) يوضح أهم الصفات التي يجب أن يتحلى بها القائم بالاتصال في مجال الدعوة

\begin{tabular}{|c|c|c|c|c|c|}
\hline 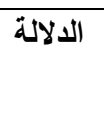 & الدالة & قيمة كا2 & $\%$ & S & صجال الدعوة القائم بالاتصال في \\
\hline- & - & 158.488 & 24.5 & 60 & العلم الوافر والقراءة في الدين \\
\hline- & - & 158.488 & 30.1 & 74 & أن يكون مؤهل دراسياً وعلمياً في مجال الدعوة \\
\hline- & - & 158.488 & 15.4 & 38 & أن بتتتع بالقدرة على التأثير في الأفراد \\
\hline- & - & 158.488 & 1.6 & 4 & أن يكون من قادة الرأي وأصحاب المشورة \\
\hline دالة & - & 158.488 & 4.1 & 10 & أن يكون في دعوته لا يبتغي سوى وجه الله \\
\hline- & - & 158.488 & 8.9 & 22 & أن يكون محافظاً على وطنه ويخاف عليه \\
\hline- & - & 158.488 & 4.5 & 11 & ألدعوة يكـون حاصـل على دورات فـي مجـال \\
\hline- & - & 158.488 & 8.5 & 21 & أن تكون الدعوة إلى الخير هدفه \\
\hline- & - & 158.488 & 2.4 & 6 & الثشعور بالمسئولية عن الأفراد في مجال الدعوة \\
\hline- & - & - & - & - & أخرى تذكر \\
\hline دالة & صفر & 158.488 & $\% 100$ & 246 & 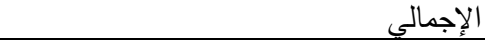 \\
\hline
\end{tabular}

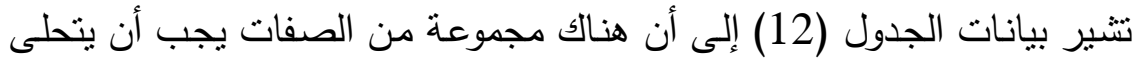
بها القائم بالاتصال في مجال الدعوة وكان أهم هذه الصفات أن يكون مؤهل دراسياً

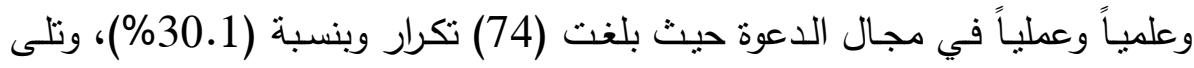
ذلك صفة العلم الوافر والقراءة والإلمام بعلوم الدين حيث بلغت (60) تكرار وبنسبة (24.5\%)، ثم جاءت فئة أن يتمتع بالقدرة على التأثير في الأفراد في المرتبة الثالثة

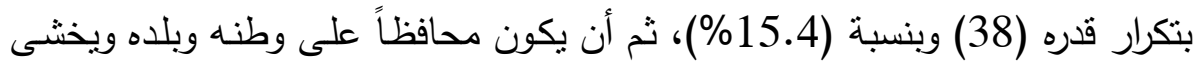
عليها بتكرار (22) وبنسبة (8.9\%) ثم أن يكون الدعوة إلى الخير هدفه (21) تكرار

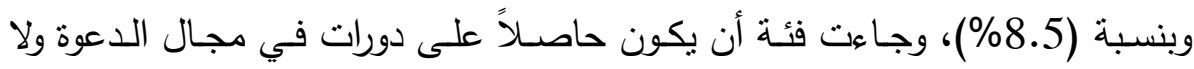

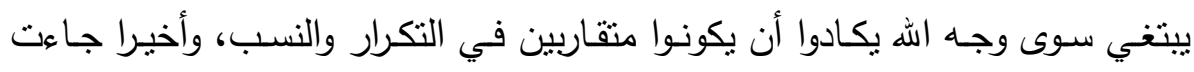
فئتي الثـور بالمسئولية عن الأفراد في مجال الدعوة بنسبة (2.4\%) وفئة أن يكون

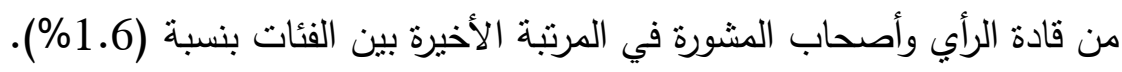
يتضح من ذلك أن أهم الصفات الواجب توافرها في القائم بالاتصـال في مجال

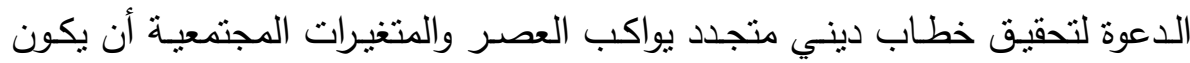


مؤهلاً دراسياً وعلميـاً وأزهريـاً ومـن أصـاب العلم الـوافر والاطـلاع الدائم والقراءة

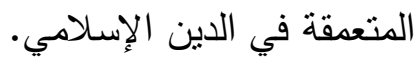
جدول (12) أهم الاحتياجات للأئمة والدعاة من أجل تحقيق تجليد واقعي للذطاب الايني

\begin{tabular}{|c|c|c|c|c|c|}
\hline الدلالة & الدالادي & 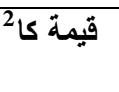 & $\%$ & ك & أهمية الاحتياجات للائمة والدعاة ك، \% \\
\hline- & - & 33.829 & 44.7 & 110 & رفع مستوى معيشة الأئمة والدعاة \\
\hline & - & 33.829 & 28 & 69 & تقتيفيفه والاهتمام بثقافتهر الإسلامية \\
\hline دالة & - & 33.829 & 21 & 53 & تحقيق معدل مرتفع من الرضا الوظيفي \\
\hline & - & & & - & عدم الإقلال من شأنهم داخل المجتمع \\
\hline- & - & - & 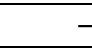 & - & 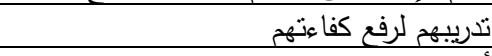 \\
\hline$=$ & - & - & 6.3 & 14 & ي ي تنكر \\
\hline دالة & صفر & 33.829 & $\% 100$ & 246 & (بمالى \\
\hline
\end{tabular}

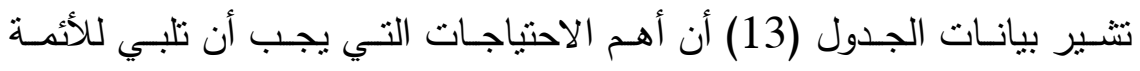

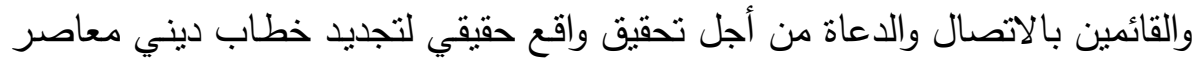
ومواكب لكافة الأحداث ومساير للعصر الذي نعيش فيه بعد فترة النحول الديمقراطي

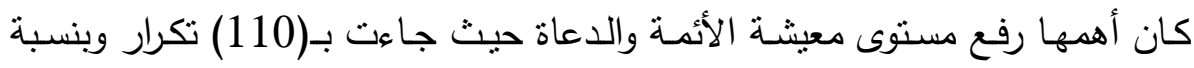

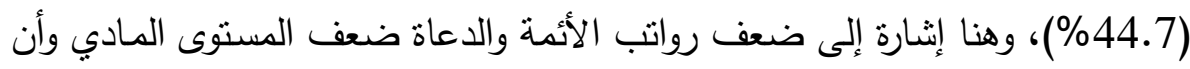

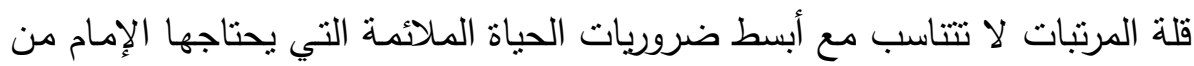

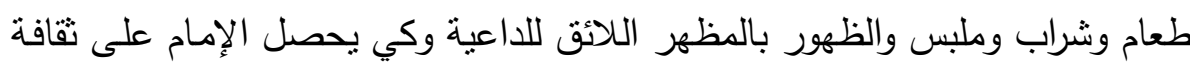

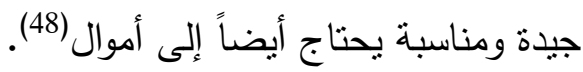

وهناك مطالبة بألا يقل الراتب للإمام عن 5 آلاف جنيه شهرياً كما أن هنالك

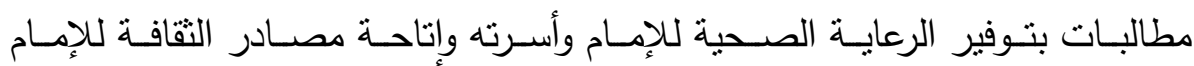
وتزويدهم بأمهات الكتب وإقامة الدورات التدريبية لهم (49).

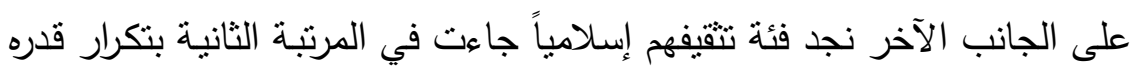
(69) وبنسبة (28\%)، وذلك لأن الإمام يحتاج إلى ثقافة دينية تمكنه من أداء عمله الداء على أكمل وجه ويجب أن توفر عملية التققيف هي وزارة الأوقاف. ثم جاءت فئة تحقيق معدل مرتفع من الرضـا الوظيفي للإمـام والدعاة أيضـاً

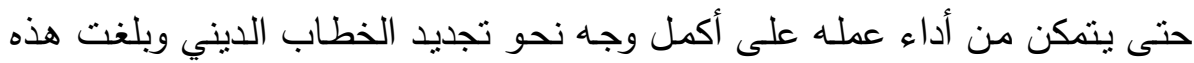
الفئة (53) تكرار وبنسبة (21\%). 


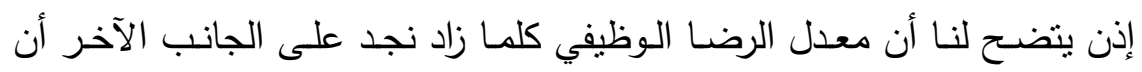

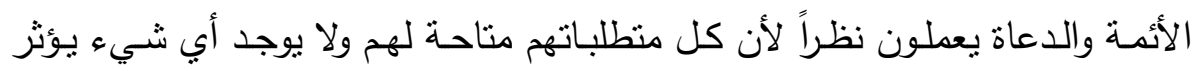
على معدل الرضا الوظيفي.

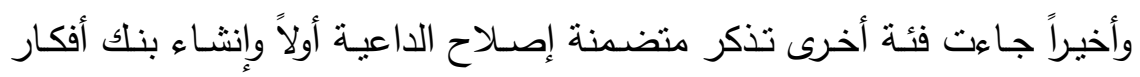

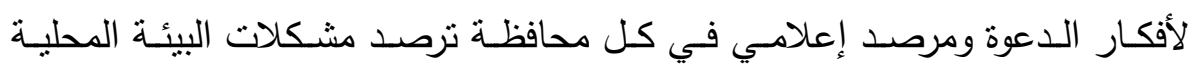

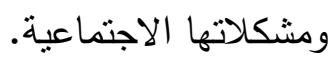
وكذللك يُدرس للاعاة النسق المعرفي الإسـامي والذي يبدأ مـن إدراك مصـادر

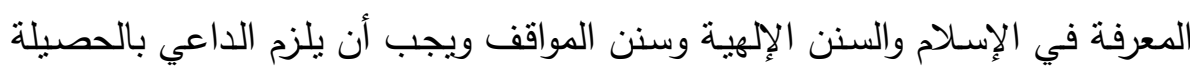

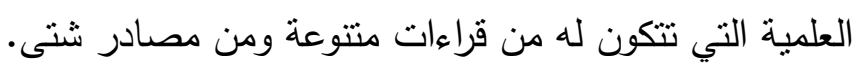

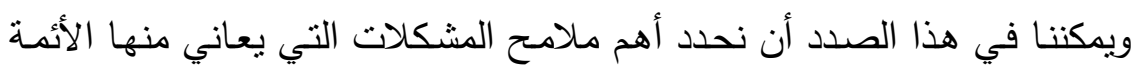
والدعاة وهي ضعف المسنوى المادي وضعف المستوى العلمي. جدول (13) أهم المقترحات لتحقيق تجديد الخطاب الديني

\begin{tabular}{|c|c|c|c|c|c|}
\hline الالالة & 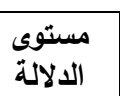 & قيمة كا2 & $\%$ & كا & \% ، ك \\
\hline- & - & - & - & - & والتتركيز على القضايا التي تدعو إلى الترابط \\
\hline- & - & - & - & - & الدعوة إلى نبذ العنف والتفرقة \\
\hline- & - & - & - & - & عدم الاختلاف في صحيح الدين \\
\hline 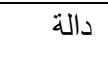 & - & 73.805 & 9.6 & 24 & تصـيح الـرؤى الخاطئة عن طريق وسـائل \\
\hline- & - & 73.805 & 20.4 & 50 & نقد وجهات النظر الأخرى بأسلوب حضاري \\
\hline- & - & 73.805 & 22.8 & 56 & عدم الإساءة إلى الغبر في الخطاب الديني \\
\hline- & - & 73.805 & 47.2 & 116 & المواكبـمعـة الخطــــاب الــديني مـــع القضـــايا \\
\hline- & - & - & - & - & الاهنتمـام بلغـــة الخطــاب لتتاســـب كافــة \\
\hline- & - & - & - & - & أخرى تذكر \\
\hline 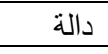 & صفر & 73.805 & $\% 100$ & 246 & الإجمالى \\
\hline
\end{tabular}

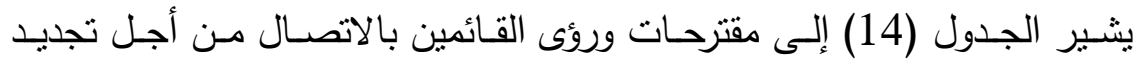

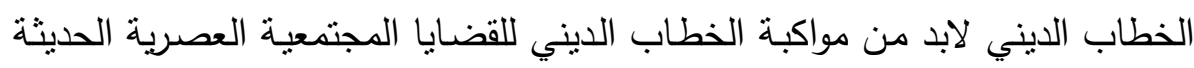

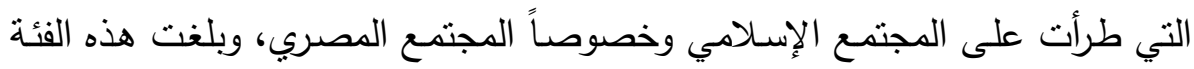
(116) نكرار وبنسبة (47.2\%). 
ثم جاءت فئة عدم الإساءة إلى الغير في الخطاب الديني الدعوي الصحيح حيث

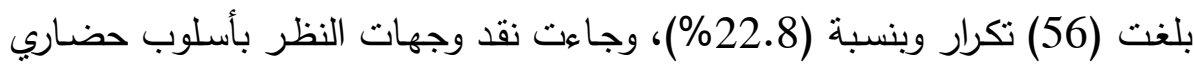

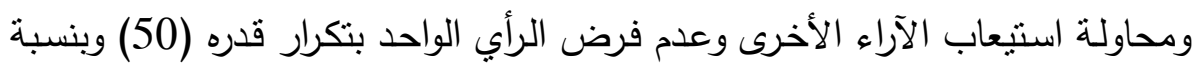

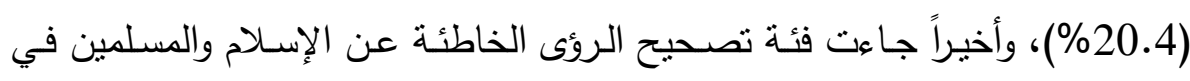

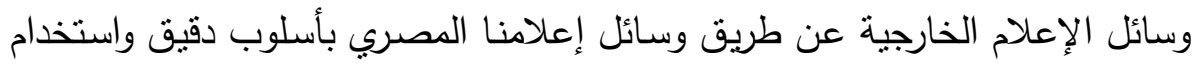

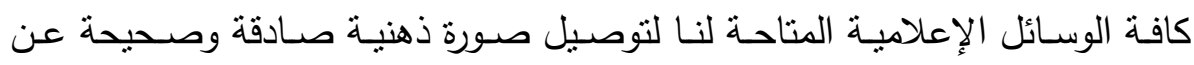
الإسلام والمسلمين وأن الإسلام دين تسامح وتعايش مع الآخرين. وكذللك استيعاب الآخرين بآرائهم وعدم الإسـاءة لهم أيضاً في الخطاب الدياب الديني المتجدد ومسايرة القضايا والمستجدات المجتمعية بكافة أنثكالها وصورها.

الإجابة على فروض الدراسة:

جدول (14) الفرض الأول تجديد الخطاب الديني يأتي لاستجابة لضروريات دينية وحياتيه.

\begin{tabular}{|c|c|c|c|c|c|c|}
\hline الالالة & مستوى & قيمة (ختبار & الدلالة & مستوي & قيمة إحصاء (اختبار & الدريةة \\
\hline دالة & 0.00 & -23.9 & دالة & 0.00 & 62.5 & 490 \\
\hline
\end{tabular}

يثير الجدول (15) إلى أن هناك فروق معنوية ذات دلالة إحصائية في الفرض الفاب

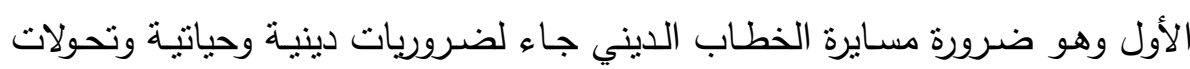

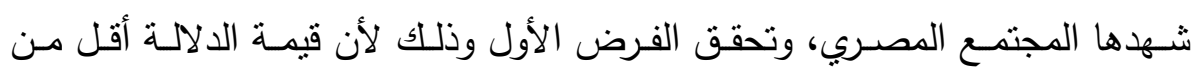
0.05 وهذا يدل على صحة الفرض الأول.

جدول (15) الفرض الثاني: يوضح العلاقة الارتباطية بين الأساليب الإقناعية

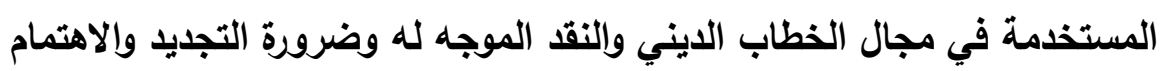
بالقائمين بالاتصال في مجال الاعوة

\begin{tabular}{|c|c|c|c|c|}
\hline الدلالة & الدلالة & ن ن & معامل ارتباط & العبارات \\
\hline دالة & 0.001 & 246 & 0.69 & "* ألهم الأساليب الإقناعية المستخدمة في مجال \\
\hline
\end{tabular}


بالتحقق من صحة الفرض الثالث وهو وجود علاقة ارتباطية ذات دلالة إحصائية بين الأسـاليب الإقناعية في مجال الخطاب الديني والنقد الموجه له وضرورة التجديد

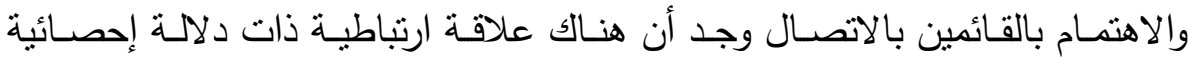

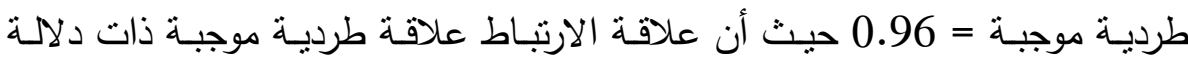

$$
\text { إحصائية بدرجة دلالة = } 0.001 \text {. }
$$

جدول (16) الفرض الثالث: يوضـح العلاقة بين الضوابط اللازمة لتجديد الخطاب الديني في مصر والمضامين التي يجب التركيز عليها

\begin{tabular}{|c|c|c|c|c|}
\hline الدلالة & مستوى & ن & معامل ارتباط & العبارات \\
\hline دالة & 0.040 & 246 & 0.87 & " * * الضوابط اللازمة لتجديد الخطاب الديني في \\
\hline
\end{tabular}

تشير بيانات الجدول (17) أن هناك علاقة ارتباط طردية موجبة = 0.87 ذات

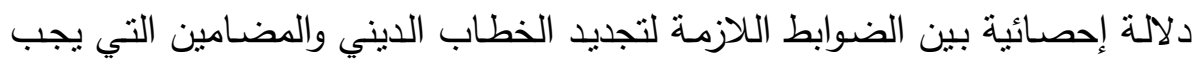
التركيز عليها في هذه المرحلة ما بين ثورة يناير 2011 ويدل ذللك على أنه لابد من

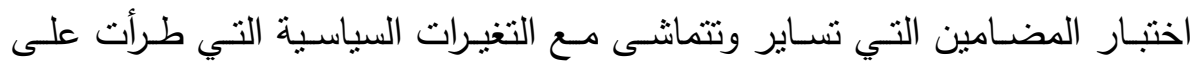
المجتمع المصري ويوضح ذلك أن هناك علاقة ارتباط (موجبة) ذات دلالة إحصائية وبثتبت ذلك صحة هذا الفرض.

جدول (17) الفرض الرابع: توجد فروق معنوية دالة إحصائياً بين كلاً من الاتجاهين بالنسبة للقائمين بالاتصال التابعين لوزارة الأوقاف وغيرهم مثل الإخوان

$$
\text { واتجاهات أخرى }
$$

\begin{tabular}{|c|c|c|c|c|c|c|}
\hline الالالة & مستوي & قيمة إحصاء & الدلالة & مستلوي & قالتيمة إحصاء (ف) & الحرية \\
\hline دالة & 0.035 & 0.361 & دالة & 0.048 & 0.490 & 490 \\
\hline
\end{tabular}

تشير البيانات بالجدول (18) أنـه توجد فروق ذات دلالـة إحصـائية معنويـة بين كلاً من الاتجاهين بالنسبة للقائمين بالاتصال بالنسبة للتابعين لوزارة الأوقاف وآخرين

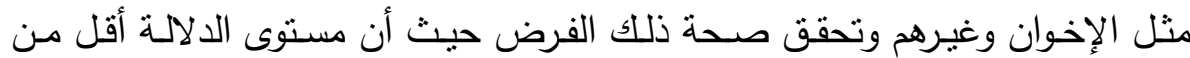
0.05 وهذا دال إحصائياً على وجود فروق معنوية بين كلا الاتجاهين. 
جدول (18) الفرض الخامس: يوضح وجود علاقة ارتباط ذات دلالة إحصائية بين رؤى القائمين بالاتصال وضوابط الخطاب الايني

\begin{tabular}{|c|c|c|c|c|c|c|}
\hline الدلالة & مستوي & $\begin{array}{c}\text { قصليمة } \\
\text { T-test }\end{array}$ & اللالالة & الالالة & قالتجانسة إحصاء) & الدرجة \\
\hline دالة & 0.028 & 2.2 & دالة & 0.001 & 11.819 & \\
\hline
\end{tabular}

تثبير بيانات الجدول (19) أنه فعـاً وجدت علاقة ارتباط ذات دلالة إحصائية

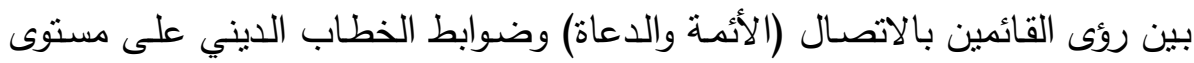

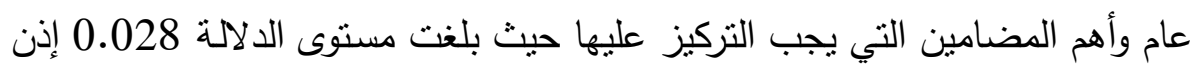

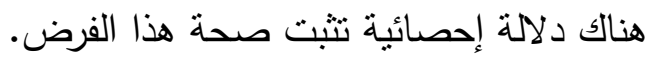
جدول (19) الفرض السادس: يوضح العلاقة الارتباطية بين أهم القضايا التي

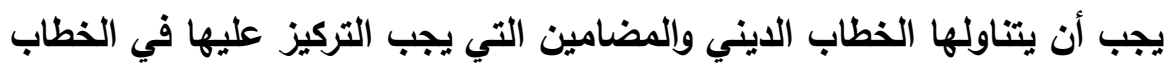

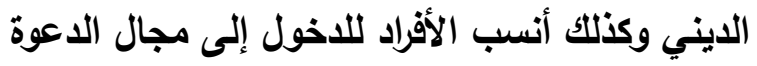

\begin{tabular}{|c|c|c|c|c|}
\hline الالالة & مستوى & ن & معامل ارتباط & العبارات \\
\hline دالة & 0.023 & 246 & 0.88 & 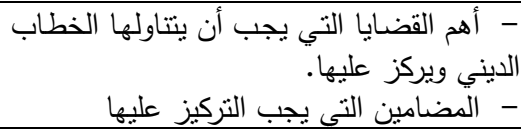 \\
\hline دالة & صفر & 246 & 0.91 & 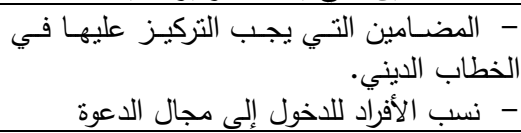 \\
\hline دالة & 0.003 & 246 & 0.092 & 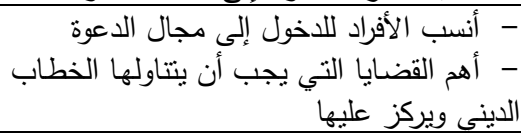 \\
\hline
\end{tabular}

يشير الجدول (20) أنه بالتحقيق من صحة العلاقة الارتباطية بين أهم القضايا

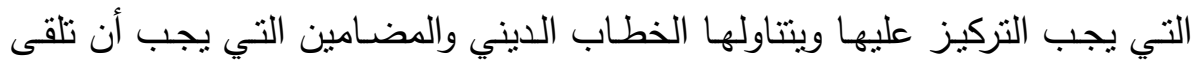

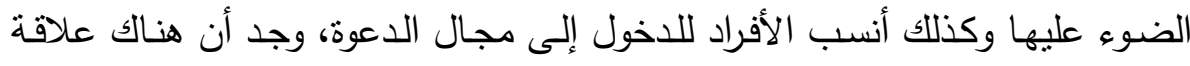

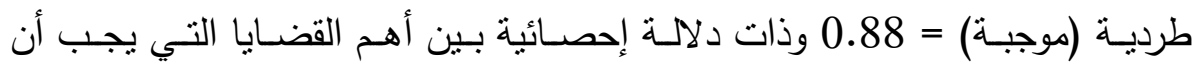

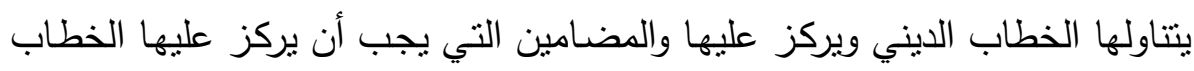

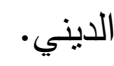
كمـا وجد علاقـة ارتباطيـة طرديـة موجبـة = 0.91 ذات دلالــة إحصـائية بـين

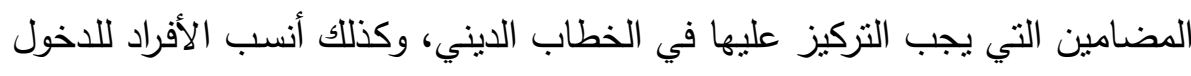
إلى مجال الدعوة. - المين 
وفي هذا السياق نشـرت جريدة الجمهوريـة تحـ عنـوان (قصـر الخطبـة على الخى الأزهريين والمساجد الجامعة، منع غير الأزهربين من تحفيظ القرآن)(50). وهذا يثبت صحة الفرض بأن هناك علاقة ارتباطية ذات دلالة إحصائية بالنسبة لأهم القضـايا التي يجب أن يتتاولها الخطاب الديني والمضـامين التي يجب التركيز عليها وأنسب الأفراد للاخول إلى مجال الدعوة.

جدول (20) يوضح بعض المقاييس الوصفية البسيطة لاستجابات العينة مثل الوسط الحسابي والانحراف المعياري.

\begin{tabular}{|c|c|c|}
\hline المعيارى الإنحراف & الوسط الوسي & العبـــارة \\
\hline 38 & 1,17 & 1- هل ترى أن الخطاب الدينى فى مصر يحتاج إلى تجديد وتطوير ؟ \\
\hline 90 & 1,52 & 2- ما هي الجهات المعنية بتجديد الخطاب الدينى ؟ \\
\hline 975 & 1,38 & 3- التجديد فى الخطاب الدينى نحتاج الية داخليا وخارجيا \\
\hline 95 & 1,28 & 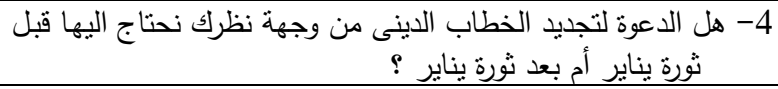 \\
\hline 964 & 2,49 & 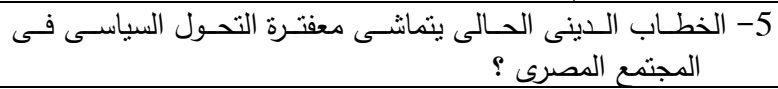 \\
\hline 1966 & 2,31 & 6- ما هي الضوابط الازمة لتجديد الخطاب الدينى فى مصر ؟ \\
\hline 1943 & 2,30 & 7- هلى اهم القضايا التى يجب أن يتناولها الخطاب الدينى ويركذ \\
\hline 1984 & 3,22 & 8- هناك مضامين يجب النزكيز عليها في الخطاب الدينى ؟ \\
\hline 96 & 1,69 & 9- - إختر انسب هؤلاء الأفراد للاخول إلى مجال الدعوة ؟ \\
\hline 1961 & 1,96 & 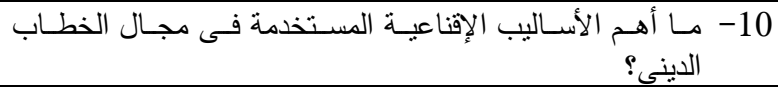 \\
\hline 1929 & 3,13 & 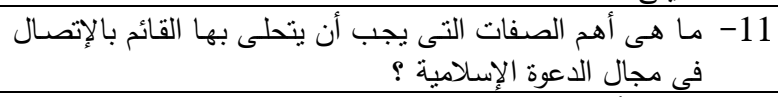 \\
\hline g799 & 1971 & 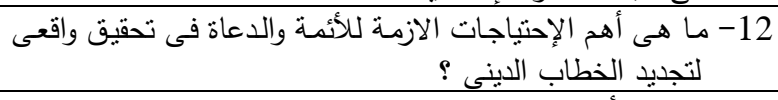 \\
\hline 1903 & 6,07 & 13- ما هي أهنم المقترحات من وجهة نظرك لنحقيق المراد من تجديد \\
\hline
\end{tabular}

\section{: نتائج الاراسة :}

خرجت الدراسة بعد هذا العرض للإطار النظري والإطار الميداني بمجموعة من

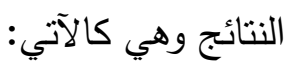

1- إن المجتمع المصري في أثند الاحتباج وأمس الحاجة إلى تجديد الخطاب

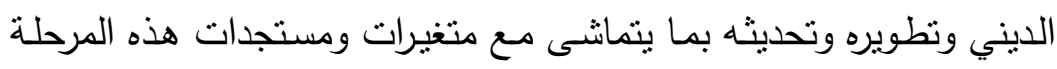
حيث أثنارت نسبة (82.4\%) بأننا نحتاج إلى تجديد الخطاب الديني. 
2- أوضحت نتائج الدراسـة أيضـاً إلى أن وزارة الأوقاف والأزهر الثريف هما

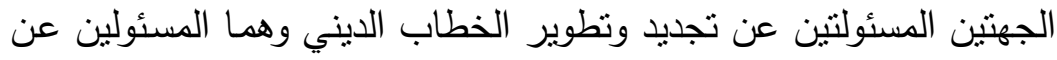

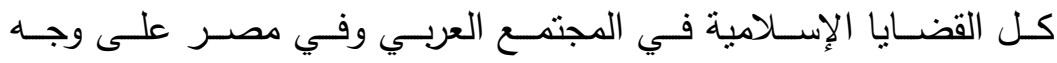
الخصوص ويبدو ذلك في إجابات المبحوثين حيث أنثارت نسبة (52.4\% الإني

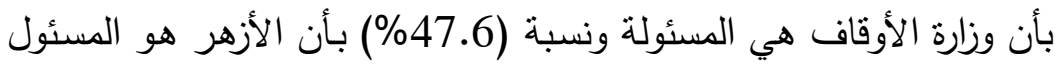
إذن مسئولية مشتركة ومتضامنة بينهم.

3- الاحتباج لتجديد الخطاب الديني داخلياً بنسبة (78\%) (78) ثم خارجياً بنسبة

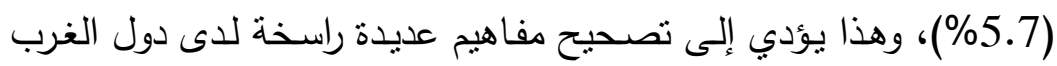

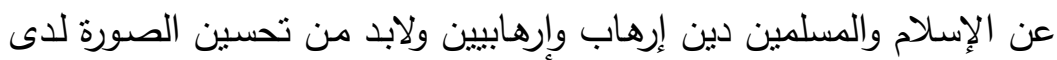

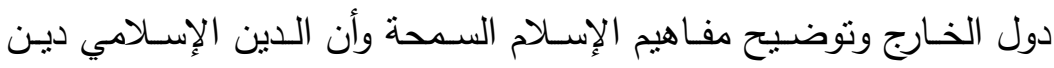
سلام ولا يدعو للعنف واستخدام القوة ضد الغير الإنام الغير

4- تجديد الخطاب الديني في المجتمع المصري نتج عن تغيرات دينية وحياتية وتحولات مجتمعية شهدها المجتمع الهصري في الفترة الأخيرة. 5- إن الخطاب الديني الحسالي لا يتمانشى مـع التحول السياسي الذي شهـهـ

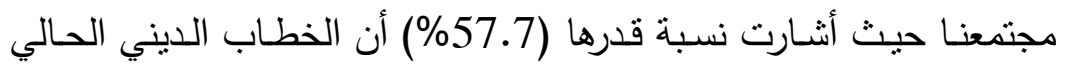
والواقع لا يتمانشى مع فترة التحول السياسي. 6- توجد مجموعة من الضوابط لتجديد الخطاب الديني بحيث أن التجديد لا

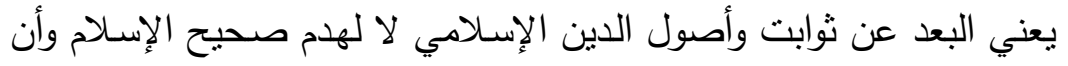

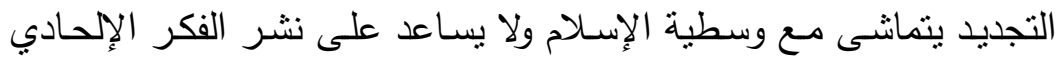

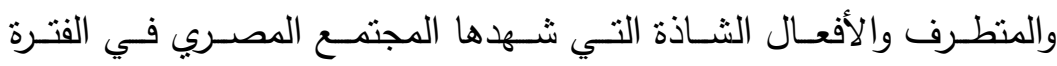

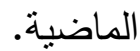
7- نوجد قضايا يحتاج الخطاب الديني أن ينضمنها ويشملها في سياقه وهي

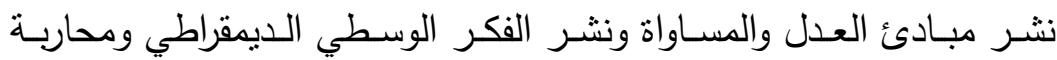
الإرهاب والتطرف مع بيان أضرار الإرهاب والتطرف الفكري أيضاً واحترام وقبول الآخر والتأكيد على سماحة الإسلام. 
8- أن أفضل الأفراد لدجال الدعوة هما رجال الأزهر الثريف والأوقاف والذين

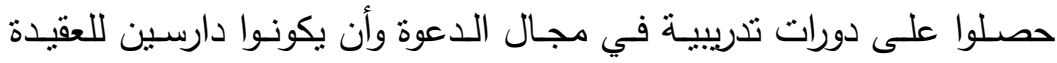
والفلسفة الإسلامية ومتخصصون في مجال الدعوة فقط. 9- أن الخطاب الديني وتجديده لن يأتي بجديد ولن يؤتي ثماره إلا عن طريق الدعوة بالموعظة الحسنة والحكمة. 10- توجد بعض الصفات يجب نوافرها في الداعيـة الإسـلامي وهي المؤهل

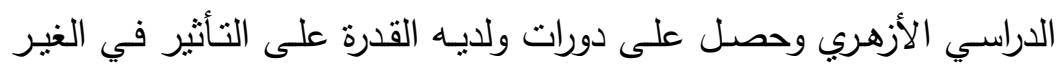

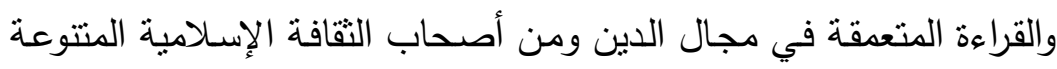
وأن يشعر بمسئولية وهو يعمل في مجال الدعوة. 11- هناك بعض الاحتياجات التي لابد من نوافرها للأئمسة واللدعاة من أجل

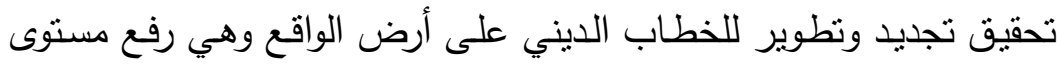

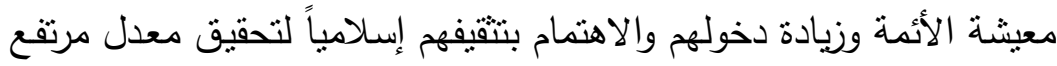
من الرضا الوظيفي.

12- توجد مقترحات من جانب أفراد الدراسـة لتحقيق تجديد حقيقي للخطاب

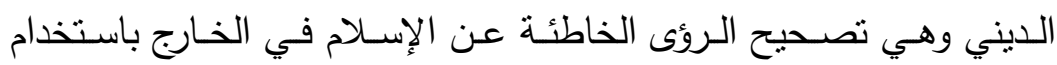
وسائل الإعلام الدصرية مثل الفضائية المصرية والصحف المصرية الإنية الدولية

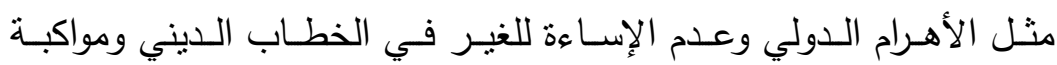

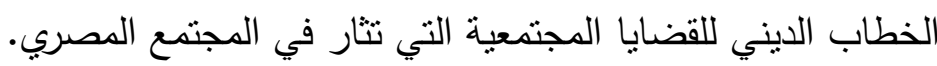
توصيات الدراسة : كما خرجت الدراسة بمجموعة من النوصيات وهي: 1- لابد من تجديد الخطاب الديني ومواكبة متغيرات عصرية فرضت نفسها على المجتمع المصري. 2- أن يناقش الخطاب الديني كافة القضـايا المجتمعية في مجتمعنا وأن يهنت بقضايا الثباب والعمل والتتمية. 


$$
\begin{aligned}
& \text { 3- الخطاب الديني لابد لـه أن ييتعد عن لغـة التعصب والترهيب الذي يؤدي } \\
& \text { إلى نفور الأفراد عند الحديث في مواضيع دينية. } \\
& \text { 4- الاهتمام بالأئمة والدعاة ورفع مستواهم المادي وكذلك الثقافي. } \\
& \text { 5- أن يعـالج الخطـاب الديني قضـايا التعصـب والإرهـاب والتطـرف والإلحساد } \\
& \text { وتكفير الغير وبيان حرمة ذلك. } \\
& \text { 6- يجب أن يواكب الخطاب الديني متغيرات المرحلة السياسية التي تشهـها } \\
& \text { كافة المجتمعات. } \\
& \text { 7- تجديـد الخطـاب الـديني واجـب مـع الحفـاظ علـى ثوابـت وصـحيح الـدين }
\end{aligned}
$$

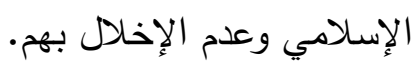




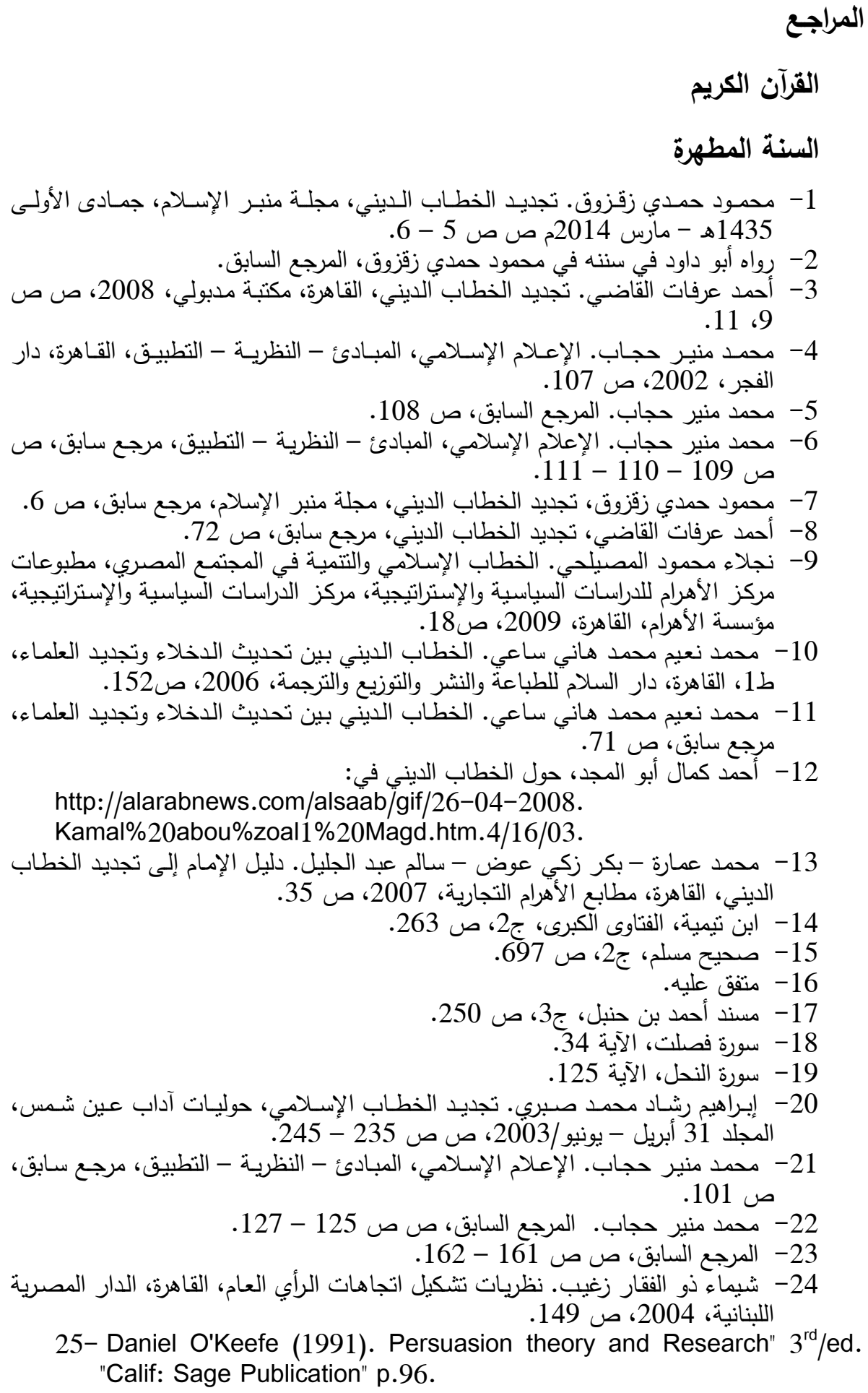

25- Daniel O'Keefe (1991). Persuasion theory and Research" $3^{\text {rd }} /$ ed.

"Calif: Sage Publication" p.96. 
26- Michael Miller and Timothy Levine (1996). Persvasion "In Michael Salwen and Don W. S taks (Eds.) "An Integrated Approach to Communication theory and research" (New Jersey, Lawrence Erlbaum Associates, Publishers", p.264.

$$
\text { 27 شيماء ذو الفقار زعيب، مرجع سابق، ص ص } 150 \text { - } 151 \text { - } 151 .
$$

28- J. Puckett et al. (1983). "The Relative Impact of Age and Attractiveness Stereotypes on Persuasion" Journal of Gerontology, Vol.38, pp. $340-343$.

29- M. Hessacker Richard E. Petty and John T. Cacioppo (1983). "Field Dependence and Attitude change: Source credibility can alter persuasion by Affecting Message Relevant thinking" Journal of personality, Vol.51, pp. $653-666$.

30- RE. Smith and D.R. Shaffer (1995). "Speed of speech and persuasion, Evidence for Multiple Effects" Personality and Social psychology Bulletin Vol.21, pp. 1051-1060.

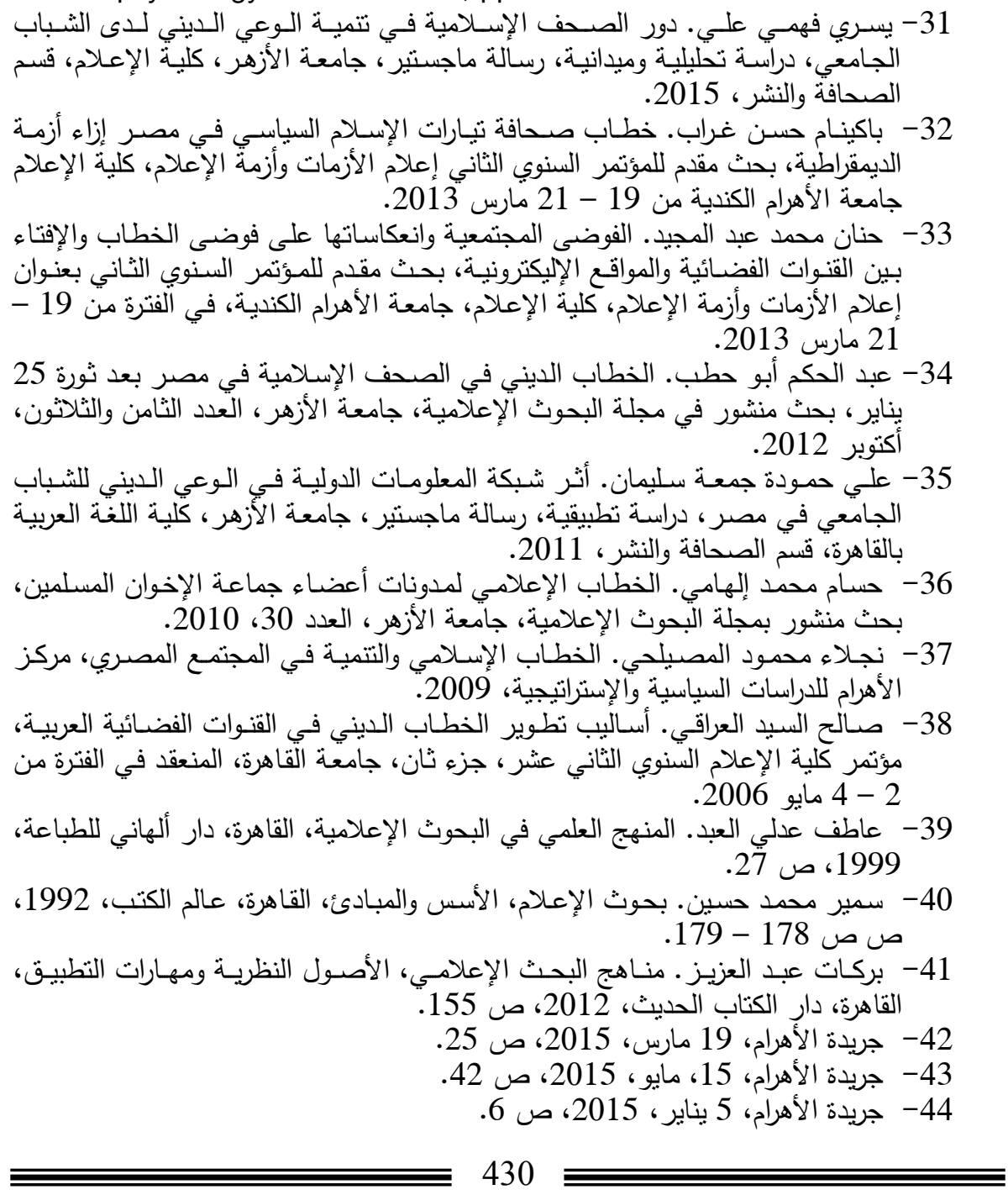


45- جريدة الأهرام، 2 يناير، 2015، ص ص 4 ،

46- جريدة الأهرام، 2 يناير، 2015، 2015، صن صن 2015، صن

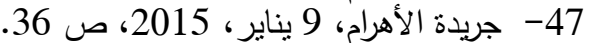

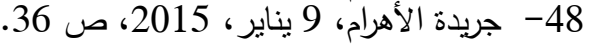

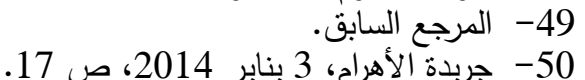




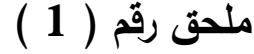

\section{معالى فضيلة وكيل وزارة الأوقاف بالشرقية}

مقده لسبادتكم الثكتور / محد عي أبو العلا قنديل

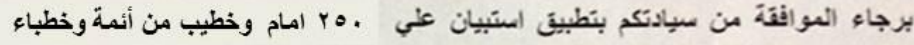

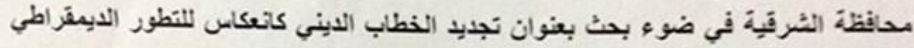

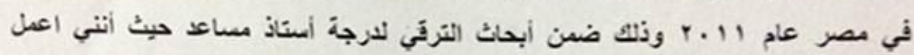

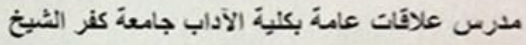

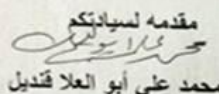

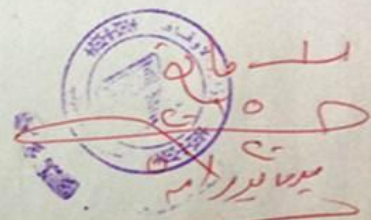




\title{
ملحق رقم (2)
}

جامعة كفر الثيخ

كلية الآداب

قسم الإعلام

\author{
استمارة استبيان حول \\ اتجاهات القائمين بالاتصال في المجال الديني من قضية تجديد الخطاب الديني \\ دراسة ميانية
}

\author{
إعداد \\ د. محمد علي أبو العلا \\ مدرس العلاقات العامة بكلية الآداب \\ جامعة كفر الثيخ
}

2015

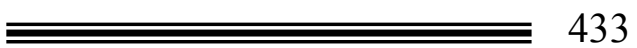




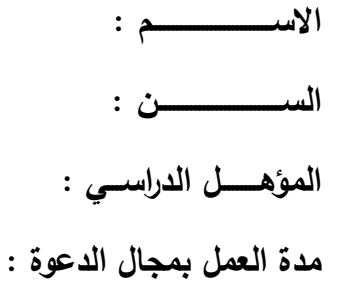

س1: هل ترى أن الخطاب الليني في مصر يحتاج إلى تحليد وتطوير؟

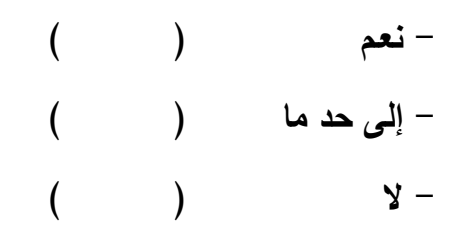

س2: ما هي الجهات المعنية بتجديد الخطاب الديني؟

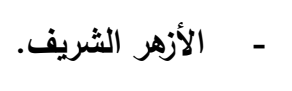

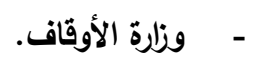$$
\text { - - - - - المراكز الإسلامية في الخارج. }
$$

- - السفارات والقتصليات (الملحقين الدينيين).

س3: التجليد في الخطاب الديني نحتاج إليه داخلياً وخارجياً:

$$
\text { - }
$$

س4: الخطاب الليني الحالي يتماثى مع فترة التحول السياسي في المجتمع الدصري؟ - - يتماشى مع فترة التحول السياسي.

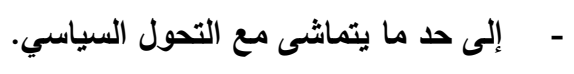
- - ل اليتماشى مع فترة التحول السياسي. 
س5: ما هي الضوابط اللازمة لتجديد الخطاب الايني في مصر؟ - - لا يتعارض مع صحيح الإسلام. - أن يركز الخطاب على بساطة وسماحة الإسلام ووسطيته. - ل أئتي الخطاب الديني بأشياء غير موجودة في الإسلام. - ألا يساعد الخطاب الايني على نثر الفكر المتطرف في الدين. - أن يكون الخطاب الديني لضبط توازن المجتمع وعدم انهياره.

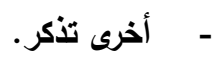

س6: ما أهم القضايا التي يجب أن يتناولها الخطاب الايني ويركز عليها؟ - - - مالعدل والمساواة بين جميع الأفراد. - - منر الفكر الديمقراطي السليم بين الأفراد. - التأكيد على مبدأ التكافل داخل المجتمع الإسلامي. - ضرورة احترام وقبول الآخر. - - الالتزام بالتعاون مع الدول الأخرى. - التأكيد على سماحة الاين الإسلامي. - توضيح دور الإسلام في محاربة ومواجهة الإرهاب والتطرف. س7: هناك مضامين يجب التركيز عليها في الخطاب الديني: - المضامين التي تتعلق بالمعاملة مع الغير. - - المضامين التي تدعو إلى نثر القيم الإيجابية. - - المضامين التي تدعو إلى أعمال الخير. - المضامين التي تدعو إلى تماسك المجتمع. - المضامين التي تدعو إلى نثر المساواة والعدل. - المضامين التي تدعو إلى حب المجتمع والمحافظة عليه. - المضامين التي تدعو إلى وحدة الدول العربية. 
- المضامين التي تدعو إلى تربية الفرد في الإسلام. - المضامين التي تدعو إلى نبذ العنف والتفرقة والتثرذم.

$$
\text { - }
$$

س 8: اختر أنسب هؤلاء الأفراد للاخول إلى مجال الدعوة؟

$$
\begin{aligned}
& \text { - داعية متخصص. } \\
& \text { - - علماء الأزهر. }
\end{aligned}
$$

- بعض الأفراد الذين يرغبون في الدعوة (علماء الدين).

$$
\text { - }
$$

س9: ما أهم الأساليب الإقتاعية المستخدمة في مجال الخطاب الديني؟

$$
\text { - }
$$

س10: ما هي أهم الصفات التي يجب أن يتحلى بها القائم بالاتصال في مجال الدعوة الإسلامية؟

- أن يتحلى بالعلم الوافر والقراءة المتعقة في الدين.

- أن يكون مؤهل دراسياً وعلمياً في مجال الدعوة.

- أن يتمتع بالقدرة على التأثير في الغير.

- أن يكون من قادة الرأي ذوي التأثثر والمشورة.

- أن يكون في دعوته لا يبتغي إلا وجه الله.

- - أن يكون محافظاً لبلاه ولوطنه ويخاف عليهما.

- - 
- - - أن تكون الدعوة إلى الخير هي هدفه.

- - م الشعور بالمسئولية عن الغير في مجال الدعوة.

- - - - - - أخرى تذكر.

س11: ما أهم الاحتياجات اللازمة للأئمة والدعاة في تحقيق واقعي لتجليد الخطاب الايني؟

- - - مفع مستوى معيثة الأئمة والدعاة.

- متثقيفه والاهتمام بثقافتهم الإسلامية.

- - - - - تحقيق معدل مرتفع من الرضا الوظيفي.

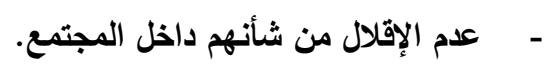

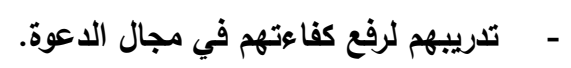

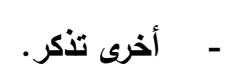

س12: ما هي أهم المقترحات من وجهة نظرك لتحقيق المراد من تجديد الخطاب الايني؟

$$
\begin{aligned}
& \text { - التركيز على القضايا التي تدعو إلى التماسك. } \\
& \text { - - الدعوة إلى نبذ العنف والتفرقة. } \\
& \text { - - عدم الاختلاف في صحيح الدين. }
\end{aligned}
$$

- - - استخدم وسائل الإعلام وتصحيح الرؤى الخاطئة.

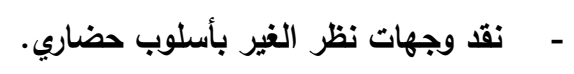

- - عدم الإساءة إلى الغير في الخطاب الديني.

- - مواكبة الخطاب الليني مع القضايا المجتمعية.

- الاهتمام بلغة الخطاب الايني لتناسب كافة مستويات الأفراد.

- - - أخرى تذكر. 